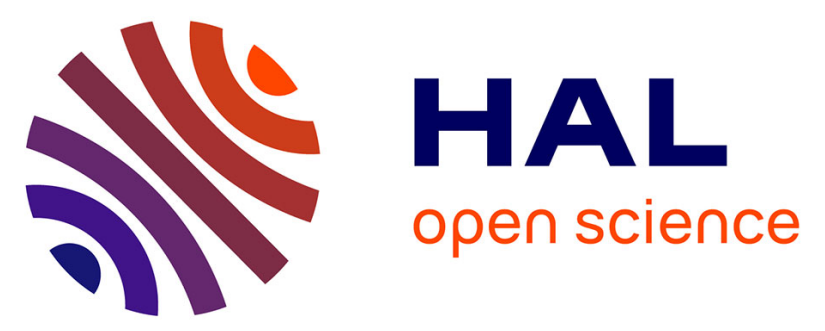

\title{
The Nappe des Marbres unit of the Basque-Cantabrian Basin: the tectono-thermal evolution of a fossil hyperextended rift basin
}

Maxime Ducoux, Laurent Jolivet, Jean-Paul Callot, Abdeltif Lahfid, Charles Aubourg, E. Masini, E. Homonnay, Florence Cagnard, Charles Gumiaux, Thierry Baudin

\section{To cite this version:}

Maxime Ducoux, Laurent Jolivet, Jean-Paul Callot, Abdeltif Lahfid, Charles Aubourg, et al.. The Nappe des Marbres unit of the Basque-Cantabrian Basin: the tectono-thermal evolution of a fossil hyperextended rift basin. Tectonics, 2019, 38 (11), pp.3881-3915. 10.1029/2018TC005348 . insu02288781

\section{HAL Id: insu-02288781 https://hal-insu.archives-ouvertes.fr/insu-02288781}

Submitted on 22 Nov 2019

HAL is a multi-disciplinary open access archive for the deposit and dissemination of scientific research documents, whether they are published or not. The documents may come from teaching and research institutions in France or abroad, or from public or private research centers.
L'archive ouverte pluridisciplinaire HAL, est destinée au dépôt et à la diffusion de documents scientifiques de niveau recherche, publiés ou non, émanant des établissements d'enseignement et de recherche français ou étrangers, des laboratoires publics ou privés. 


\section{Tectonics}

\section{RESEARCH ARTICLE \\ 10.1029/2018TC005348}

Key Points:

- The Nappe des Marbres Unit shows structures related to a preserved hyperextended basin, reactivated during later inversion

- Temperatures related to the HT-LP Pyrenean metamorphism show some of the highest values of the entire belt, postdating early salt tectonics

- These results show that there is no large-scale maximum temperature gradient along the Internal

Metamorphic Zone (IMZ) across the Pyrenean belt contrasting with previous assumptions

Supporting Information:

- Supporting Information S1

- Table S1

Correspondence to

M. Ducoux,

maxime.ducoux@univ-orleans.fr

Citation:

Ducoux, M., Jolivet, L., Callot, J.-P., Aubourg, C., Masini, E., Lahfid, A., et al (2019). The Nappe des Marbres unit of the Basque-Cantabrian Basin: The tectono-thermal evolution of a fossil hyperextended rift basin. Tectonics, 38 . https://doi.org/10.1029/2018TC005348

Received 2 OCT 2018

Accepted 10 AUG 2019

Accepted article online 9 SEP 2019

(c)2019. American Geophysical Union. All Rights Reserved.

\section{The Nappe des Marbres Unit of the Basque-Cantabrian Basin: The Tectono-thermal Evolution of a Fossil Hyperextended Rift Basin}

\author{
M. Ducoux ${ }^{1,2,3,4,5}$ (D) L. Jolivet ${ }^{6}$ (D) J.-P. Callot ${ }^{7}$, C. Aubourg ${ }^{7}$, E. Masini ${ }^{8,9}$, A. Lahfid ${ }^{2}$, \\ E. Homonnay ${ }^{7,8,10}$, F. Cagnard ${ }^{2}$, C. Gumiaux ${ }^{1,2,3}$, and T. Baudin ${ }^{1,2,3}$ \\ ${ }^{1}$ ISTO, UMR 7327, Université d'Orléans, Orléans, France, ${ }^{2}$ BRGM, ISTO, UMR 7327, Orléans, France, ${ }^{3} \mathrm{CNRS} / \mathrm{INSU}$, UMR \\ 7327, Orléans, France, ${ }^{4}$ Now at CSTJF, Total SA, Pau, France, ${ }^{5}$ Now at E2S-UPPA, University of Pau and Pays Adour- \\ CNRS-TOTAL, LFCR IPRA, UMR 5150, Pau, France, ${ }^{6}$ Sorbonne Université, CNRS-INSU, ISTeP UMR 7193, Paris, France, \\ ${ }^{7}$ E2S-UPPA, University of Pau and Pays Adour-CNRS-TOTAL, LFCR IPRA, UMR 5150, Pau, France, ${ }^{8} \mathrm{CSTJF}$, Total SA, \\ Pau, France, ${ }^{9}$ M\&U SAS, Saint-Égrève, France, ${ }^{10}$ Géoazur, UMR 7329, Valbonne, France
}

\begin{abstract}
The architecture of the Pyrenean-Cantabrian belt results from the inversion of a series of former Cretaceous rift basins. A HT-LP metamorphic event dated at 105 to $85 \mathrm{Ma}$ ago is commonly associated with an Albo-Cenomanian episode of hyperextension of the continental crust. This metamorphism is well known in the eastern Basque-Cantabrian Basin within the Nappe des Marbres Unit (NMU) that is preserved from intense compressional deformation during the Pyrenean orogeny. Based on a structural study at the scale of the eastern Basque-Cantabrian Basin and on a dense sampling for $T_{\mathrm{RSCM}}$ estimates with the Raman spectroscopy of carbonaceous material (RSCM) method (Raman Spectrometry on Carbonaceous Material), we show following results: (1) the NMU has recorded two major phases of deformation, related to a localized extensional ductile foliation $\left(\mathrm{S}_{1}\right)$ during the Cretaceous rifting and later by the regional N-S shortening, recorded by a regional cleavage $\left(\mathrm{S}_{2}\right)$ observed only in shale sediments. (2) The NMU is affected by early salt tectonics related to several diapirs and salt walls fed by the Upper Triassic evaporitic layer. (3) The NMU recorded maximum temperatures exceeding $550^{\circ} \mathrm{C}$, which represent some of the highest temperatures along the Pyrenees. These new data demonstrate that there is no E-W lateral metamorphic gradient across the belt and that hyperextension rifting occurred consistently within a high-thermal regime; (4) metamorphic isograds are oblique in respect of the main structures, suggesting that the metamorphic event postdates most of the early salt-related deformations prior to or coeval with early stages of rifting. As it represents one of the best preserved example of preorogenic hyperextended basin, the eastern Basque-Cantabrian Basin record may be used regionally to better understand the rift to orogen evolution of the Pyrenean Internal Metamorphic Zone but also more generally as an analog of salt-bearing hyperextended rift record.
\end{abstract}

\section{Introduction}

The way tectonics, sedimentation, and thermal evolution interact at the end of magma-poor rifting before lithospheric break-up and onset of seafloor spreading still remains poorly understood. This history is actually recorded along present-day distal domains of magma-poor rifted margins, and on the field in a few known outcropping examples (e.g., the Tasna domain; Manatschal et al., 2006). Because these domains are often lying in ultradeep offshore settings, deeply buried beneath postrift sediments, they have been rarely drilled and calibrated despite being a main target for oil and gas industry. Based on scarce well results, geophysics, or numerical modeling, an increasing number of papers document variable architectures of hyperextended rifted margins (e.g., rift symmetry/asymmetry, domains of hyperthinned crust or exhumed mantle, supradetachment and sag basins, and extensional folds) that are commonly associated with thermal anomalies going along hydrothermal fluid circulations (e.g., Autin et al., 2010; Lavier \& Manatschal, 2006; Leroy et al., 2012; Nonn et al., 2017; Osmundsen \& Ebbing, 2008; Péron-Pinvidic \& Manatschal, 2009; Péron-Pinvidic \& Osmundsen, 2016;Reston, 2009; Sutra et al., 2013). Understanding the synrift behavior of these magma-poor margins requires to get 3-D structural and thermal constraints along conjugate pairs of margins and sets the base for predictive basin modeling in these settings. An alternative approach to offshore study is to use fossil analogs that are outcropping in mountain belts (e.g., Alps: Beltrando et al., 2014; Lemoine et al., 1987; Manatschal, 2004; Masini et al., 2012; Mohn et al., 2010); and Pyrenees: Clerc et al., 
2012, 2013; Jammes et al., 2009; Lagabrielle \& Bodinier, 2008; Lagabrielle et al., 2010; Masini et al., 2014; Tugend et al., 2014; Betics: Frasca et al., 2016).

The Pyrenean mountain belt may be an ideal candidate to study the tectono-thermal evolution of magmapoor hyperextended rift systems. Indeed, the overall understanding of this orogen is under a major revision since evidence for preorogenic hyperextension (HE) rifting and mantle exhumation were already documented across the belt (Clerc et al., 2012, 2013; Jammes et al., 2009, Jammes, Lavier, et al., 2010; Lagabrielle \& Bodinier, 2008; Lagabrielle et al., 2010; Lagabrielle et al., 2016; Masini et al., 2014; Tugend et al., 2014, Teixell et al., 2016) and is becoming one of the typical examples of a mountain belt derived from the inversion of an aborted hyperextended rift. However, the role of former rift-related inheritances for orogeny remains debated as the HE record and associated HT-LP metamorphism could have been intensely overprinted by Pyrenean shortening, obscuring the original synrift geometrical relationships. The basin where HE was unveiled for the first time (Aulus Basin and Lherz peridotite massif; Lagabrielle \& Bodinier, 2008) was so tightly shortened during the Pyrenean orogeny that it is difficult to reconstruct the preshortening geometry. This paper focuses on a detailed study of the Nappe des Marbres Unit (NMU), in the eastern BasqueCantabrian Basin in the western termination of the Pyrenean orogen, where the compressional deformation has been less intense and the early and preorogenic basin architecture and thermal record related to the HE processes are better preserved.

The aim of this paper is twofold: (1) to determine and refine the structure of the NMU and (2) to characterize the distribution of HT-LP metamorphism related to the rifting stage. The basin was systematically explored in the field with detailed structural data acquisition, associated with a dense sampling for estimating the maximum temperature recorded by the metasediments using the Raman spectroscopy of carbonaceous material (RSCM) method (e.g., Beyssac, Goffé, et al., 2002) to infer the connections between the presentday structure and Cretaceous HT-LP metamorphism.

\section{Geological Settings}

\subsection{The Pyrenean-Cantabrian System}

The Pyrenees consist in an intracontinental belt resulting from contraction between Iberian and Eurasian lithospheric plates from Late Cretaceous to Miocene Epochs. The E-W striking belt is 1,000 km long, from Galicia in the west to Provence in the east (Figure 1). The Pyrenean architecture results from the inversion of a series of former rift basins emplaced along the boundary between the Iberian and Eurasian plates during the late Aptian to the late Coniacian-early Santonian Stages (Clerc et al., 2012, 2013; Jammes et al., 2009, Jammes, Lavier, et al., 2010; Lagabrielle \& Bodinier, 2008; Lagabrielle et al., 2010; Lagabrielle et al., 2016; Masini et al., 2014; Tugend et al., 2014). After Variscan orogeny, lithospheric extension is polyphazed and starts as early as the Permian as recorded by the development of large crustal structures combining normal, strike-slip, and transfer faults (Arthaud \& Matte, 1975, 1977). The subsequent Triassic rifting consist of the development of NE-SW striking normal faults (Thinon, 1999) that probably reactivated former Variscan structures (Curnelle et al., 1982). Resulting from the northward propagation of the Atlantic between North America and Iberia going along the opening of the Bay of Biscay and the relative motion of Iberia and Europe (e.g., Barnett-Moore et al., 2016; Boillot, 1986; Le Pichon et al., 1971; Macchiavelli et al., 2017; Nirrengarten et al., 2018; Olivet, 1996; Roest \& Srivastava, 1991; Sibuet et al., 2004; Srivastava et al., 1990; Tavani et al., 2018), the main rifting event in the Iberia-Europe plate boundary is recorded during the Late Jurassic-Cretaceous by the formation of extensional basins (e.g., Biteau et al., 2006; Boillot et al., 1973; Boillot, 1984; Brunet, 1984; Canérot, 1989; James et al., 1996; Jammes et al., 2009; Peybernes \& Souquet, 1984; Vergés \& García-Senz, 2001; Tugend et al., 2015). This event was characterized by the formation of several segmented rift basins (Peybernes \& Souquet, 1984) along the Bay of Biscay Pyrenean system (e.g., Parentis, Basque-Cantabrian, Mauléon-Arzacq, Organya, and their North Pyrenean Zone (NPZ) inverted equivalents; Figure 1). Subcontinental ultramafic bodies are exposed sporadically in the NPZ and are testifying of a preorogenic extreme crustal thinning ultimately leading to mantle exhumation (e.g., Clerc et al., 2012, 2013; Fabriès et al., 1991, 1998; Lagabrielle \& Bodinier, 2008; Lagabrielle et al., 2016). If such an extreme amount of crustal thinning came to reach a broad consensus in the last decade, the underlying lithospheric extension, its kinematics, and the resulting tectono-stratigraphic evolution remains debated. Indeed, the extensional basins were first interpreted as pull-apart basins during left-lateral oblique movement of the 


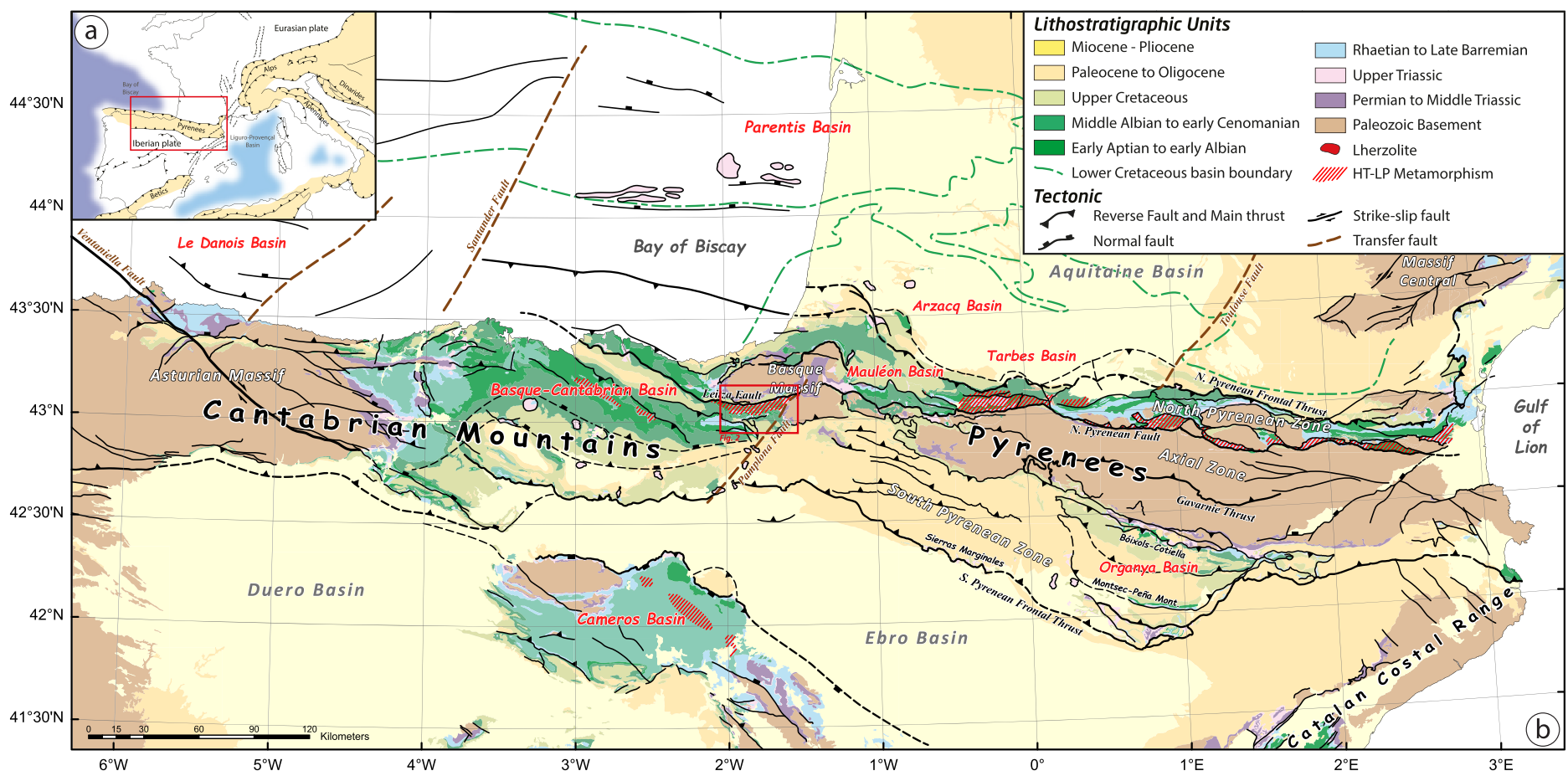

Figure 1. Tectonic and geological framework of the Pyrenean-Cantabrian belt. (a) Main collision related geological features of the Western Mediterranean collision belts. (b) Geological map of the Pyrenean-Cantabrian collision belt (after 1 million-scale Geological Map of Spain and Geological Map of France, with UTM 30N projection), with location of Figure 2.

Iberian Plate along one major crustal fault in the Pyrenees known as the North Pyrenean Fault (NPF; Choukroune \& Mattauer, 1978; Handy et al., 2010; Le Pichon et al., 1970; Olivet, 1996; Stampfli et al., 2002). Mostly based on plate kinematic modeling, they were also interpreted as back-arc or oceanic margin basins and related to the subduction of a north dipping oceanic slab beneath the Eurasian Plate (Sibuet et al., 2004; Vissers \& Meijer, 2012; Vissers et al., 2016). More recent models further proposed that the movement of Iberia relative to Europe was accommodated within a wide, diffuse plate boundary along which E-W striking basins that record HE developed during the late Aptian to Albian (Canérot, 2017; Jammes et al., 2009, Jammes, Lavier, et al., 2010; Lagabrielle \& Bodinier, 2008; Lagabrielle et al., 2010; Tugend et al., 2014) coinciding with the onset of seafloor spreading in the Bay of Biscay (Montadert et al., 1979). In these models, the Cretaceous HE was accommodated by detachment fault systems concentrated in the NPZ that are relayed to the SW in the Basque-Cantabrian Basin across the so-called Pamplona transfer fault (Pedrera et al., 2017; Roca et al., 2011; Tugend et al., 2014). Kinematic of these main structures remains strongly debated because the polarity and the asymmetry are themselves discussed. Even studies are proposing transtensional kinematics on these structures actually (e.g., Canérot, 2017).

The Cretaceous crustal thinning event is also associated with a regional high-temperature and low-pressure metamorphism referred to as the Pyrenean metamorphism (Azambre \& Rossy, 1976; Bernus-Maury, 1984; Clerc et al., 2015; Clerc \& Lagabrielle, 2014; Dauteuil \& Ricou, 1989; Golberg \& Leyreloup, 1990; Ravier, 1959). Metamorphic rocks associated to this HT-LP metamorphism occurred within E-W striking corridor corresponding to the so-called Internal Metamorphic Zone (IMZ). Along the Pyrenees, they are found north of the NPF and are shifted south of the Leitza Fault across the Pamplona Fault going into the eastern part of the Basque-Cantabrian Basin, corresponding to the NMU (Figure 1). HT-LP metamorphism affects Mesozoic sediments affected by a HT-LP metamorphism, reaching temperatures up to $600^{\circ} \mathrm{C}$ below 4 kbar for the NPZ (Bernus-Maury, 1984; Clerc et al., 2015; Golberg \& Leyreloup, 1990; Vauchez et al., 2013). It is noteworthy that the compilation of available temperature estimates, obtained by RSCM method along the IMZ, was supporting a gradual increase of peak-temperature from west to east (Clerc et al., 2015). Published geochronological data indicate ages ranging from Albian to Santonian (110-85 Ma) for this HT-LP metamorphic event (Albarède \& Michard-Vitrac, 1978a; Albarède \& Michard-Vitrac, 1978b; Chelalou 
et al., 2016; Clerc et al., 2015; Golberg \& Maluski, 1988; Montigny et al., 1986; Golberg et al., 1986; Bandet and Gourinard in Thiébaut et al., 1988) from which the younger ages are coeval with the onset of Pyrenean shortening. The NPZ and the Basque-Cantabrian Basin areas were also affected by two magmatic events during the Mesozoic. The first one occurred during the Triassic and was responsible for the emplacement of tholeiitic dolerites referred regionally to as "ophites" (Montigny et al., 1982; Azambre et al., 1987), whereas the second is associated with a large variety of intrusive and effusive Cretaceous alkaline magmatic rocks referred to as "episyenites" (Azambre et al., 1992; Montigny et al., 1986; Rossy et al., 1992). Geochronological data on the alkaline magmatic rocks emplacement yield ages between 113 and $85 \mathrm{Ma}$ (Chelalou et al., 2016; Clerc et al., 2015; Golberg et al., 1986; Henry et al., 1998; Montigny et al., 1986), coeval with the HT-LP metamorphism, both interpreted as a consequence of the Cretaceous lithospheric thinning (Clerc et al., 2015).

HT-LP metamorphic rocks of the IMZ show an intense ductile foliation, first attributed to a Pyrenean compressional event (Choukroune, 1972, 1976) and more recently to a synextensional and/or transtensional event during the Cretaceous rifting (Clerc et al., 2015; Clerc \& Lagabrielle, 2014; Golberg, 1987; Golberg \& Leyreloup, 1990; Lagabrielle et al., 2010). The "HE" models (e.g., Clerc et al., 2012, 2013; Lagabrielle \& Bodinier, 2008; Lagabrielle et al., 2016) explain the occurrence of a localized HT-LP metamorphism by lithospheric thinning responsible of high thermal gradient and mantle exhumation directly overlain by Mesozoic sedimentary cover. However, the pervasive Pyrenean collisional overprint prevents making precise restorations of the former rift architecture in the IMZ. The best preserved its SW lateral equivalent, the NMU, is a valuable opportunity we took in this study to further detail the preorogenic rift record.

The onset of contractional deformation was recorded by Upper Santonian sediments in the South Pyrenean Zone (Garrido-Megias \& Rios 1972; García-Senz, 2002; McClay et al., 2004; Mouthereau et al., 2014Muñoz, 1992; Teixell, 1998; Vergés et al., 1995; Vergés \& García-Senz, 2001) and Santonian-Campanian heterogeneous reactivation of the northern Bay of Biscay (Thinon et al., 2001). This timing fits kinematic reconstructions based on magnetic anomalies in the Atlantic Ocean, indicated a Santonian age (84 Ma) for the onset of the convergence between Iberian and Eurasian plates (e.g., Macchiavelli et al., 2017; Olivet, 1996; Roest \& Srivastava, 1991; Rosenbaum et al., 2002). After a quiet period during the Paleocene (Danian to early Selandian, Ford et al., 2016), a major phase of compression occurred in Eocene-Oligocene Epochs (Muñoz, 1992, 2002; Mouthereau et al., 2014; Vergés et al., 2002). The resulting present-day structure of the Pyrenean belt is an asymmetric double-verging tectonic wedge above the underthrusted Iberian continental lithosphere (Beaumont et al., 2000; Choukroune and ECORS Team, 1989; Muñoz, 1992; Mouthereau et al., 2014; Roure et al., 1989; Teixell, 1998; Teixell et al., 2016; Vergés et al., 1995). Estimation of shortening shows variations along strike the belt. It is estimated at $\sim 125 \mathrm{~km}$ in the eastern Pyrenees (Vergés et al., 1995), 140-160 km in the central part (Beaumont et al., 2000; Canérot, 2016; Mouthereau et al., 2014; Muñoz, 1992), 114 km in the western part (Teixell et al., 2016), and $~ 96$ to 86 $\mathrm{km}$ in the central part of the Cantabrian Mountains and the attached continental margin (Gallastegui, 2000; Gallastegui et al., 2002; Pedreira et al., 2007).

\subsection{The Nappe des Marbres}

The study area is located in the western part of the Pyrenees, in the eastern part of the Basque-Cantrabrian basin (Figures 1 and 2). It corresponds to the so-called "Nappe des Marbres" Unit (NMU), first described by Lamare (1936) and predominantly composed of Mesozoic sediments. The NMU is surrounded by two Variscan massifs, the Cinco Villas Massif to the north and the Aldudes Massif to the east (Figures 2 and 3). Both are composed of Paleozoic metasediments affected by three phases of deformation under MT-LP metamorphic conditions related to the Variscan orogeny (e.g., Campos, 1979; Heddebaut, 1975; Heuschmidt, 1977; Juch \& Schäfer, 1974; Klarr, 1974; Krausse, 1973; Martinez-Torres et al., 1984; Pesquera \& Velasco, 1997; Richter, 1965). To the north, the south dipping Leitza fault is juxtaposing the NMU with the "Central Depression" unit ("Dépression Intermédiaire" in Lamare, 1936) corresponding to a 1- to 5-km-wide E-W linear syncline made of Upper Cretaceous calcareous flysch (Figures 2 and 3). The Leitza Fault crops out along $\sim 50 \mathrm{~km}$ from Irurita to the east to Orexa to the west (Figure 2) and is underlined by ophicalcites, large ophitic bodies, and basement shreds (DeFelipe et al., 2017; Mendia and Ibarguchi, 1991). The fact that it both represents a sharp northern boundary for the HT-LP metamorphism and a break of deformation intensity between the heavily folded NMU (isoclinal folds) and the gently folded Central 


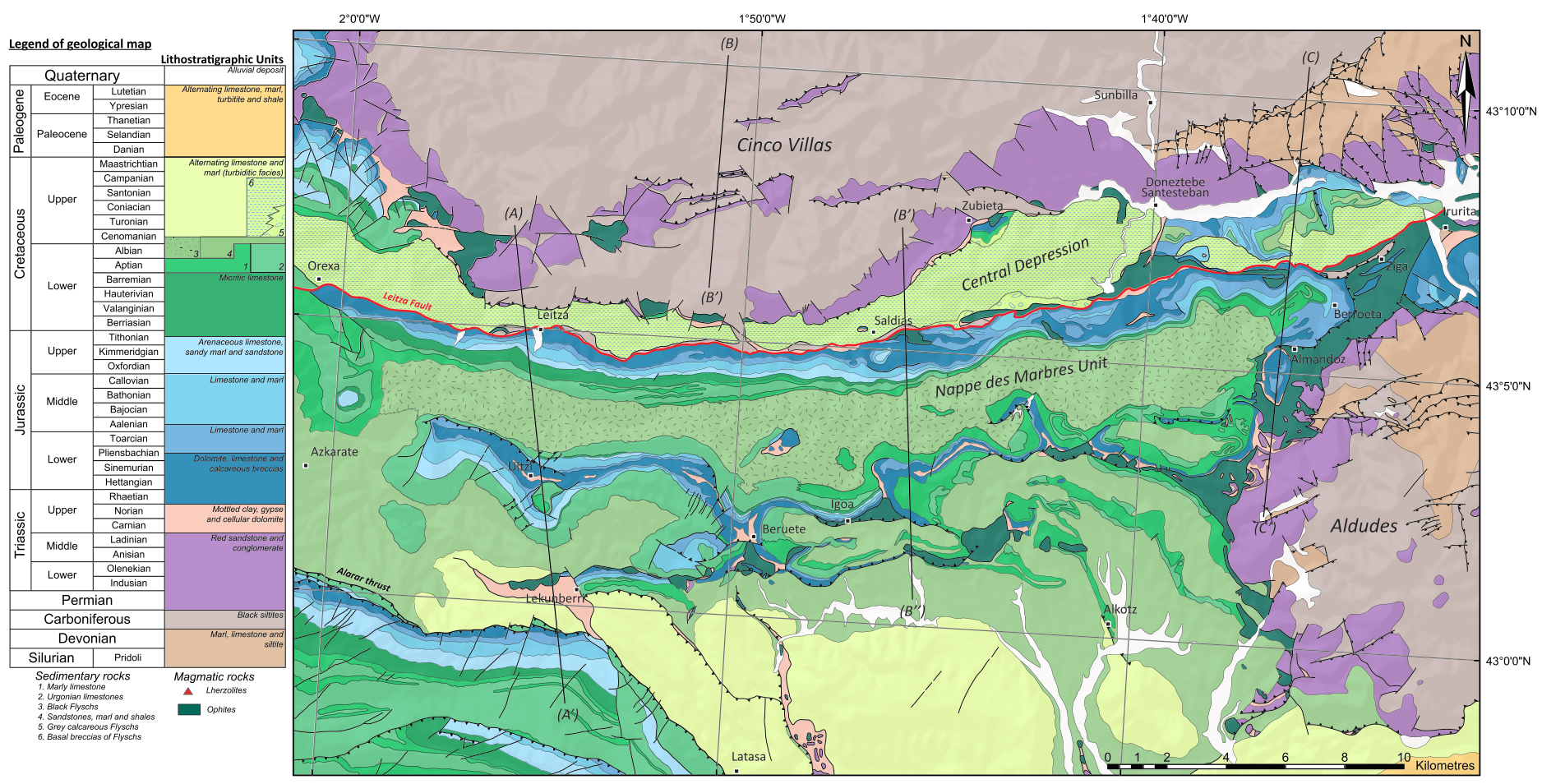

Figure 2. Geological map of the study area with location of the cross-sections (Figure 6). Modified after 1: 50000 geological maps of Vera de Bidasoa (Krausse et al., 1972) Tolosa (Gabaldón et al., 1983), Sumbilla (Del Valle et al., 1973), Gulina (Carbayo et al., 1977), and Alsasua (Gabaldón et al., 1984).

Depression led former authors to propose that the Leitza fault could be a lateral equivalent of the NPF (Boillot et al., 1973; Choukroune, 1976; Combes et al., 1998; Floquet \& Mathey, 1984; Larrasoaña et al., 2003; Martinez-Torres, 1989; Mathey et al., 1999; Mendia and Ibarguchi, 1991; Peybernès et al., 2003; Rat et al., 1983; Rat, 1988). Recently, Pedrera et al. (2017) suggested that this fault may also correspond to an inverted south-verging large-offset detachment fault related to the Cretaceous HE. The NE-SW striking limit of the NMU corresponds to the southern continuation of the so-called "Pamplona fault." The occurrence of abundant and massive ophite bodies aligned with this paleo-geographic limit for preorogenic basins led former authors to consider it as a major crustal scale structure by Triassic Period (Figures 2 and 3; Capote, 1983; Feuillée \& Rat, 1971; Larrasoaña et al., 2003; Martinez-Torres, 1989; Rat, 1988; Turner, 1996).

As for the IMZ, the NMU is affected by a HT-LP metamorphism, extending from Irurita to Leitza, within an E-W striking narrow strip that is a few kilometer wide and ends to the north along the Leitza Fault. This metamorphism is poorly constrained and was first described by Lamare (1936) who distinguished two types of metamorphism: (i) a Late Triassic contact metamorphism caused by the intrusion of ophitic bodies and (ii) a second regional metamorphism affecting Jurassic and Cretaceous sediments spatially distributed in several zones with spatially variable intensities. This second metamorphic event was first correlated with a pre-Cenomanian orogenic phase for the whole NPZ (Ravier, 1959) and associated with numerous crustal faults such as the Leitza Fault (Lamare, 1936). Available P-T estimates indicate temperatures below $500^{\circ} \mathrm{C}$ and pressures around 3-5 kbar (Martinez-Torres, 1989; Mendia, 1987; Mendia and Ibarguchi, 1991).

Metamorphic reactions affect both the prerift and synrift sediments. Keuper deposits and associated ophites show pyroxene uralitization, plagioclase albitization, and scapolite crystallization (Walgenwitz, 1977). Jurassic and lower Cretaceous limestones are metamorphosed into marbles containing scapolites (Lamare, 1936), while Albian shales are metamorphosed into hornfels. The Upper Cretaceous sediments in the Central Depression are not or only slightly affected by this HT-LP metamorphism (Martinez-Torres, 1989) and are associated with a hydrothermal event (Iriarte, 2004). 


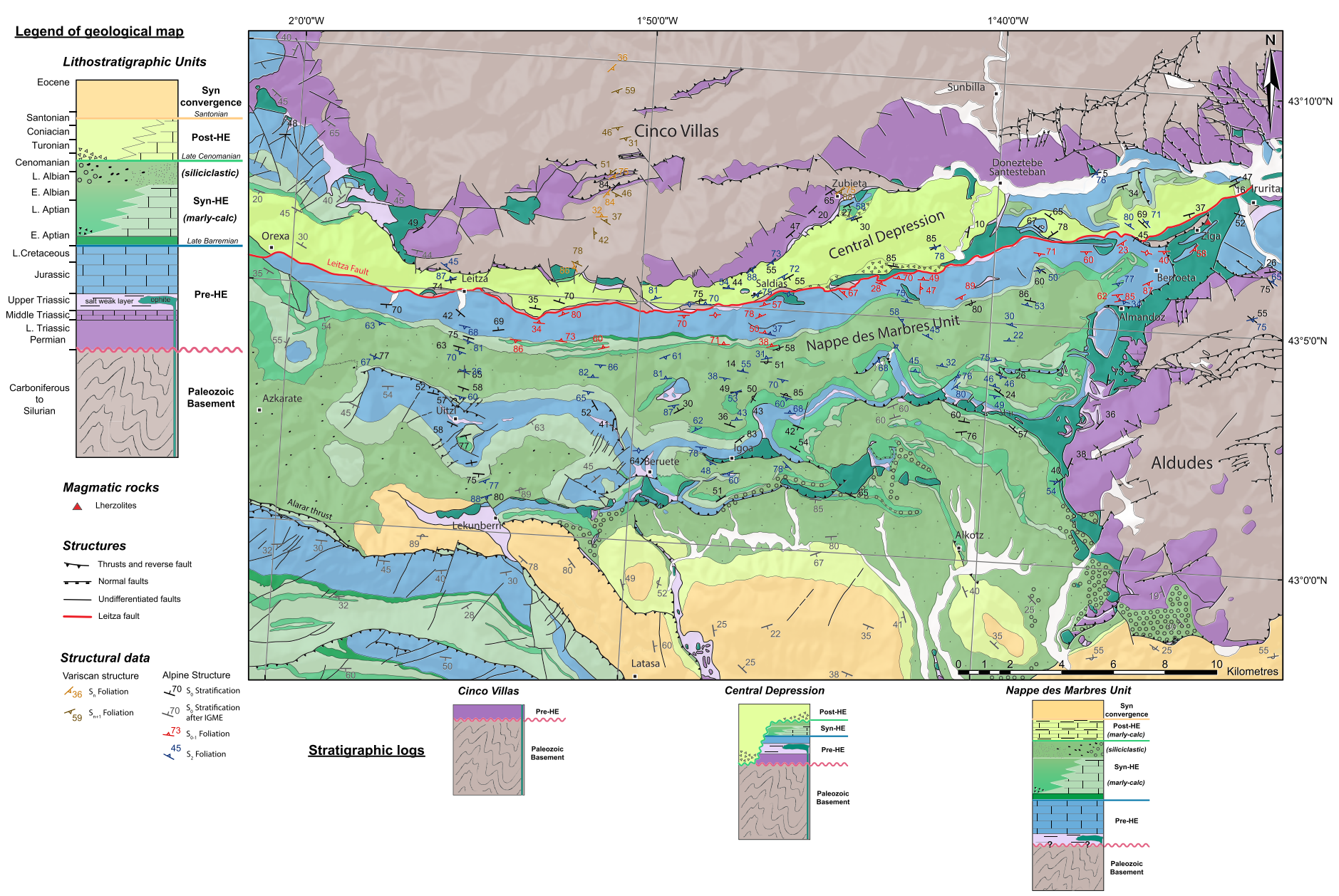

Figure 3. Simplified Geological map of the study area with simplified and representative structural data (published data and new data obtained during this work) and stratigraphic log of three different tectono-metamorphic units. Modified after 1: 50000 geological maps of Vera de Bidasoa (Krausse et al., 1972) Tolosa (Gabaldón et al., 1983), Sumbilla (Del Valle et al., 1973), Gulina (Carbayo et al., 1977), and Alsasua (Gabaldón et al., 1984).

The distribution of temperatures within the NMU caused by the HT-LP metamorphism appears rather heterogeneous (Martinez-Torres, 1989). The metamorphic grade decreases southward away from Leitza Fault with the successive development of three metamorphic isogrades (biotite, muscovite, and chlorite). Montigny et al. (1986) obtained two discordant ages of $93 \pm 3$ Ma and $81 \pm 3$ Ma with ${ }^{40} \mathrm{~K}^{-}{ }^{40} \mathrm{Ar}$ on a phlogopite and a biotite from metasediments, respectively, corresponding to the late Cenomanian-early Turonian and late Santonian-early Campanian. In addition, Albarède and Michard-Vitrac (1978a,b) obtained two ages of $101 \pm 16 \mathrm{Ma}$ with ${ }^{87} \mathrm{Rb}^{87} \mathrm{Sr}$ and $85 \pm 2 \mathrm{Ma}$ with ${ }^{40} \mathrm{Ar}-{ }^{39} \mathrm{Ar}$ on phlogopites from metasediments, that is, late Albian-early Cenomanian and early Campanian. Ages of the HT-LP metamorphic event are thus bracketed in the NMU between $81 \pm 3$ and $101 \pm 16 \mathrm{Ma}$. Those ages are slightly younger than those of the rest of the Pyrenees (Albarède \& Michard-Vitrac, 1978a; Albarède \& Michard-Vitrac, 1978b; Clerc et al., 2015; Golberg \& Maluski, 1988; Montigny et al., 1986; Bandet Y. and Gourinard Y. in Thiébaut et al., 1988).

\section{Tectono-stratigraphic Evolution of the Eastern Basque-Cantabrian Basin}

\subsection{Stratigraphic Domains Related to HE Processes: Terminology}

This paper focuses on the relationship between the metamorphism of the eastern BCB and its architectures. Various classifications define present-day hyperextended magma-poor rift systems or rift margins (e.g., Chenin et al., 2015; Péron-Pinvidic \& Osmundsen, 2016; Sutra et al., 2013; Tugend et al., 2015). These studies generally consider three main crustal zones: (i) a proximal margin domain, corresponding to a weakly 
thinned crust, (ii) a crustal necking domain corresponding to the main crustal taper through which most of the crustal thinning is accommodated, and (iii) a distal margin domain, corresponding to hyperthinned crustal domain with possible zones of exhumed continental mantle, and finally across the Ocean Continent Transition and into the oceanic crust. The HE processes are associated with strain localization and lead to the formation of necking and distal domains.

The Pyrenean, Basque-Cantabrian and Bay of Biscay areas show a succession of rift phases that attenuated the Variscan continental crust from Late Paleozoic to Cretaceous times. Therefore, it is often difficult to determine the timing, the distribution, and the relative importance of each rifting phase. The Triassic evaporites also noise the signal in the crustal extension as it is responsible for the intense prekinematic to postkinematic salt tectonics and represents a major decoupling level between crust and cover (e.g., Bodego \& Agirrezabala, 2013; Tavani et al., 2018). However, as stated above, crustal necking and mantle exhumation are diagnostic features of distal margin domains resulting from HE. Their formation accelerated the formation of the accommodation space that can be easily recognized in the sedimentary record without having to access its underlying autochthonous basement (Tugend et al., 2014). Thus, rather than ascribing a given sedimentary sequence relative to active deformation along a fault (i.e., prekinematic, synkinematic, or postkinematic) or at rift basin scale (e.g., prerift, synrift, and postrift), we chose to use the nomenclature introduced by Masini et al. (2014) relative to HE as pre-HE, syn-HE, and post-HE. This results in the definition of three riftrelated key stratigraphic markers to identify the different rift-related sequences in the NMU as (i) the base of the pre-HE sequence corresponding to the unconformable Permian-Triassic sediments above the Variscan Paleozoic Basement; (ii) the top of the pre-HE sequence corresponding to the early Aptian unconformity, related to the base of the Errenaga marls Fm. (Bodego et al., 2015 and references therein); and (iii) the top of syn-HE sequence related to the deposition of mid-Cenomanian detrictic-calcareous flysch (Figure 3). The additional late Santonian sequence boundary bounds the post-HE sequence from the syn-orogenic deposits (Garrido-Megias \& Rios Aragues, 1972; García-Senz, 2002; McClay et al., 2004; Muñoz, 1992; Teixell, 1998; Vergés et al., 1995; Vergés \& García-Senz, 2001).

\subsection{Distinction of Tectono-stratigraphic Units}

We distinguish three tectono-stratigraphic units in this paper. From north to south, these units correspond to the Cinco Villas Unit, the Central Depression Unit and the NMU (Figures 2 and 3). The Cinco Villas (or northern) unit consists of a Paleozoic Basement stratigraphically overlain by the base of pre-HE sediments (Figure 3). The remaining pre-HE sediments (Mid Triassic to Lower Cretaceous) as well as the syn-HE deposits are missing (eroded, tectonically shifted or never deposited). This configuration suggests that this unit corresponded to a paleo-high during HE. The intermediate Central Depression Unit is mainly characterized by late Turonian to Campanian calcareous flyschs corresponding to post-HE series. These deposits are composed of turbidites and calcareous mudshales affected by slumping and unconformably overlie the Cinco Villas Paleozoic and Mesozoic rocks (Mathey et al., 1999; Figure 3). Some lenticular marls and breccias are located at the base of these flyschs. They are interpreted as debris flows derived from the nearby Cinco Villas Paleozoic series located to the north and from remnants of Mesozoic cover unconformably overlying the basement further east (Figure 3). Mathey et al. (1999) suggested that the Central Depression sediments were derived from the NMU in the southern margin, as evidenced by clasts of supposed metamorphic Mesozoic limestones within the basal breccias, leading to the conclusion that the Leitza fault was active during sedimentation (Bodego et al., 2015; Ewert, 1964; Mathey et al., 1999; Peybernès et al., 2003). Planktonic foraminifers found in the conglomerate matrix indicate that these sediments were deposited from the early Turonian to early Coniacian (Mathey et al., 1999). Basal debris flow deposits, localized at the base of the Central Depression show several fragments of Paleozoic basement and Jurassic-Cretaceous sediments in a few places (Figure 4). On the northern edge of the Central Depression, we recognized clasts of the Mesozoic limestone in the Upper Cretaceous flysch that locally unconformably overlies the Cinco Villas massif near Zubieta (Figures 3 and 4b). In the western part of the Central Depression, clasts of Triassic sandstones and ophites can be reported in these debris flow deposits (Figure 4a). Locally, on the southern edge of the Central Depression, we observed several decimetric clasts of resedimented Paleozoic basement shales (Figure 4c). In the eastern part, the Central Depression overlies remnants of Mesozoic sedimentary cover, composed mainly by pre-HE (Jurassic) and syn-HE (late Aptian to Albian) deposits. It should be noted that the early Aptian series are not observed (Figure 3). In the Central Depression, pre-HE sediments correspond to platform carbonates, while syn-HE sediments consist in shallow marine carbonates during late Aptian 

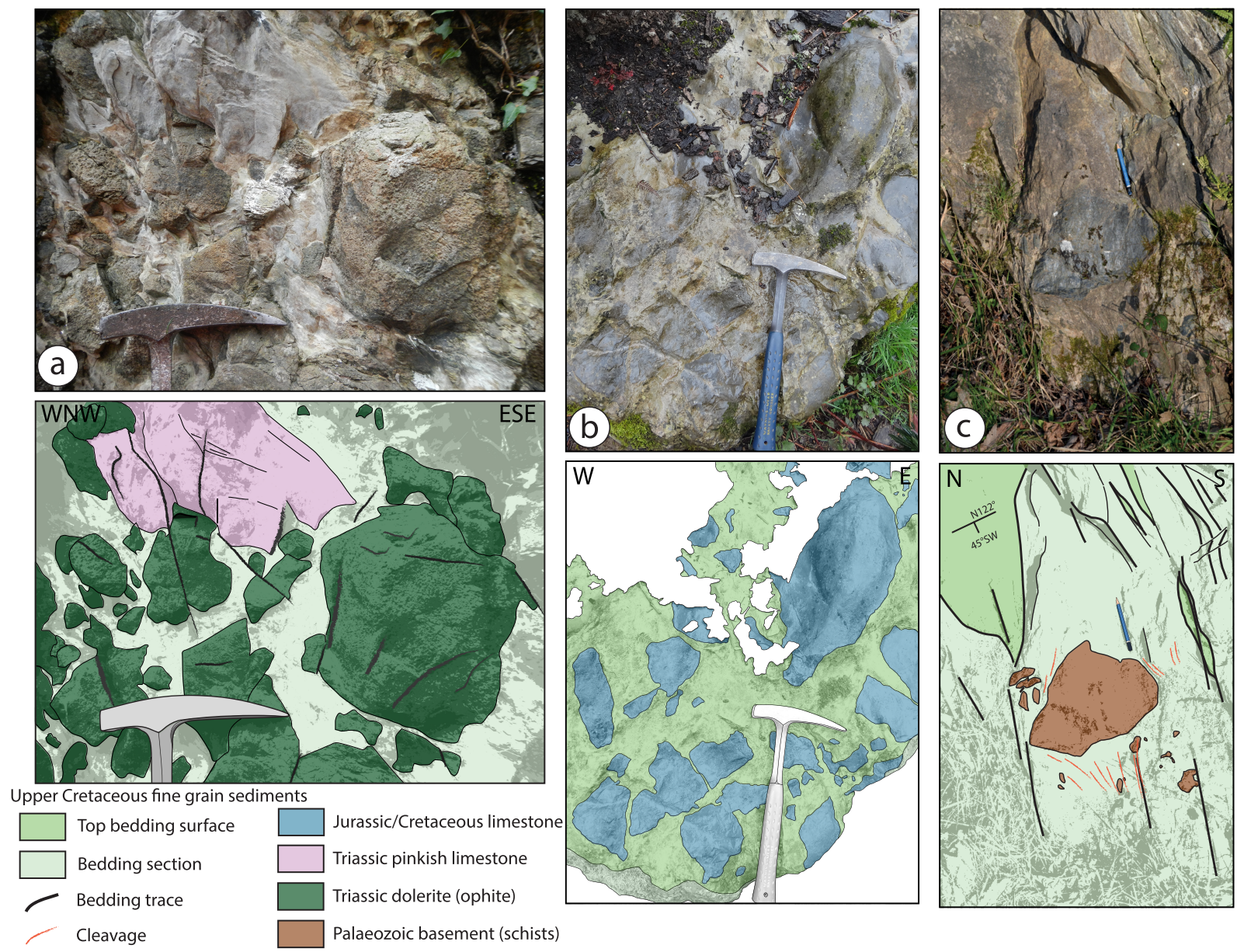

Figure 4. Field Photographs and interpretation of the clast compositions of the Central Depression sediments. (a) Debris flow composed with Triassic limestone and ophite clasts localized in the central part of Central Depression $\left(43^{\circ} 5^{\prime} 28.56^{\prime \prime} \mathrm{N}, 1^{\circ} 47^{\prime} 10.24^{\prime \prime} \mathrm{W}\right)$. (b) Debris flow composed with non-metamorphic Jurassic and Cretaceous limestone clasts localized in the central part of Central Depression $\left(43^{\circ} 7^{\prime} 3.612^{\prime \prime} \mathrm{N}, 1^{\circ} 44^{\prime} 9.229^{\prime \prime} \mathrm{W}\right)$. (c) Calcareous flysch with Paleozoic basement clasts draped by the $S_{2}$ cleavage localized in the southern part of Central Depression $\left(43^{\circ} 5^{\prime} 23.28^{\prime \prime} \mathrm{N}, 1^{\circ} 49^{\prime} 57.56^{\prime \prime} \mathrm{W}\right)$.

Stage, grading to clastic deposits with fine- to medium-grained sandstone and mudstone during Albian Stage (Bodego et al., 2015). The Albian series are attributed to an outer ramp environment below the storm wave base or inner siliciclastic shelf (Iriarte, 2004).

To the south, the Central Depression is sharply juxtaposed to the NMU by the Leitza fault zone. However, these two zones are drastically different regarding their syn-HE depositional settings. In fact, the NMU is characterized by the maximum recorded subsidence in the study area and preserves the entire pre-HE, syn-HE, and post-HE sedimentary record (Figure 3). There is no evidence of the Permian-Lower Triassic series below the Upper Triassic evaporitic layer at the base of this Unit. The widespread occurrence of Upper Triassic evaporites and ophites in the NMU strongly suggests that the bottom of the pre-HE Jurassic carbonates is underlain by the Upper Triassic sequence corresponding to the regional décollement (Figure 3). The top of the pre-HE deposits corresponds to the late Barremian carbonates, unconformably overlain by the synHE early Aptian marls (Errenaga Fm.), which are the lateral equivalent of the Sainte-Suzanne marls described in the western NPZ and the Aquitaine Basin (e.g., Biteau et al., 2006 and references therein). At the scale of the NMU, the syn-HE sedimentary sequence recorded an accelerated subsidence and the related formation of accommodation space. The upper Aptian to lower Albian deposits are characterized by synchronous reefal and bioclastic carbonate platforms in a lateral facies transition with basinal marls and deepwater terrigenous clastics (Figure 3). Significant thickness variations and internal unconformities document synsedimentary tectonic activity related to halokinesis (Bodego et al., 2015), to underlaying crustal 
thinning or most likely a combination of both processes. Furthermore, reefal and bioclastic carbonate platforms developed in shallow-water conditions. They are spatially correlated to anticlines (Figure 3), which strongly suggests that these deposits are contemporaneous to an early phase of folding (e.g., syn-HE). This configuration may result from early diapir and salt-ridge growth that generated subsea topographical highs and preshortening structures during rifting (e.g., Poprawski et al., 2016; Rat, 1988). The top of the syn-HE sequence corresponds to siliciclastic sedimentation related to widespread Albian black shale deposition comprising interbedded sandstones, shales, slumps, and scarce conglomerates deposits mostly outcropping in southeastern study area (Figure 3). These deep-water clastics can be considered as the lateral equivalent of the North Pyrenean flyschs referred to as "Flyschs noirs" or "Flyschs ardoisiers" (Debroas, 1978, 1990; Debroas \& Souquet, 1976; Souquet et al., 1985), which were sourced by emerged basement areas located at the southern margin of the basin, a similar source-to-sink situation as the Western Pyrenees (Boirie \& Souquet, 1982; Souquet et al., 1985). Where it outcrops, the post-HE consists of shallow-marine deposits ranging from Cenomanian to early Santonian in age, followed by younger Santonian synorogenic deposits characterized by marls, sandy limestones, and shales (Figure 3). This sequence consists of detritic-calcareous flysch corresponding to turbitic sedimentation.

At basin scale, the lithostratigraphic description of these three tectono-stratigraphic units documents a southward gradual increase in thickness and deepening of the depositional environments, especially for the syn-HE sequences. The climax is located at the northern termination of the NMU, where the syn-HE corresponds essentially to deep-water turbidites against the Leitza fault. The synchronous deposits of the juxtaposed Central Depression are thin continental to estuarine (Figure 3). From the facies and thickness variations between these two units, it can be deduced that the Leitza fault corresponds to a reactivated syn-HE south-dipping slope.

\section{Architecture of Eastern Basque-Cantabrian Basin: Evidence for a Complex Geometry and Several Deformation Phases}

The regional-scale structure of eastern $\mathrm{BCB}$ is characteristic of a reactivated rift basin. A series of maps produced from a compilation of structural data collected in the field and from previous published studies (Figures 2, 3, 5, and 6) illustrate the first-order structure of the study area. Based on this dataset, three N-S geological cross sections are proposed (Figure 7; see locations of the cross sections in Figure 2).

\subsection{The Role of the Triassic Evaporitic Sequence Across the BCB: Salt Tectonics and a Décollement Level}

It is commonly accepted and has been extensively described that the BCB experienced heavy salt tectonics before and during its formation and during its deformation. The BCB consists of piercing diapirs (e.g., Canérot et al., 2005; García-Mondéjar et al., 1996; Jackson \& Vendeville, 1994; Rat, 1988), with associated synsedimentary structures, unconformities with coeval lateral thickness, and facies variations (e.g., Frankovic et al., 2016; García-Mondéjar et al., 1996; Poprawski et al., 2014; Soto et al., 2017). Although synrift halokinesis is not well recognized in the eastern part of the BCB, it can be linked further east to thick-skin faults active in the subsalt basement (García-Mondéjar et al., 1996). However, the onset age of salt mobility remains enigmatic so far. Nevertheless, several occurrences of salt-related structures are documented and appear to have developed during the Late Jurassic-Early Cretaceous (e.g., Canérot et al., 2005; Tavani et al., 2013; Tavani \& Granado, 2015), early Aptian (e.g., Agirrezabala \& García-Mondéjar, 1989; Badillo, 1982; García-Mondéjar, 1982; García-Mondéjar \& García-Pascual, 1982), early Albian (Bodego \& Agirrezabala, 2013; García-Mondejar \& Robador, 1986; García-Mondéjar et al., 1996; López-Horgue et al., 2010; Poprawski et al., 2014, 2016), and late Albian (Reitner, 1982; Schroeder, 1979, Schroeder \& Willems, 1983; Wiedmann, 1979). A recent study focusing on the Central Depression emphasized that the main salt motion occurred during the Albian-Cenomanian transition, which is in agreement with the observed unconformities (Bodego et al., 2018). Based on the above-described syn-HE sedimentary evolution, one likely interpretation is that the delayed halokinesis along the Central Depression could result from the accentuation of the palaeo-"Leitza fault" slope (regional tilting/bending) toward the NMU. Such tilting is inferred from the required differential subsidence between these two units, as the NMU syn-HE sequence recorded continual subsidence, whereas the Central Depression recorded delayed subsidence, transgression, and increased 


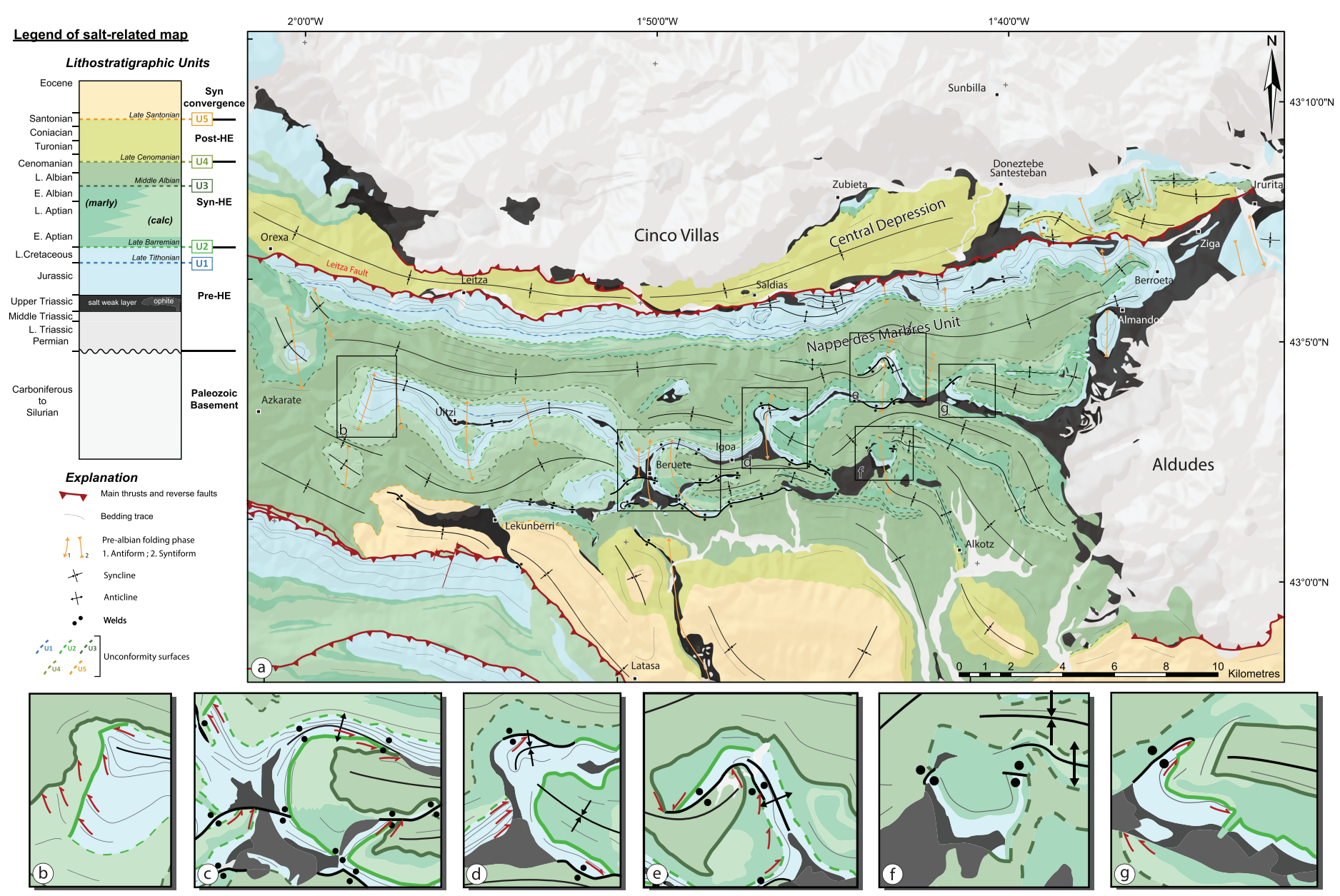

Figure 5. Salt-related map of the study area showing the different structures and unconformity related to salt tectonics and associated close-up focused on the specific geometry. The Upper Triassic sequence is represented in black, subsalt units (basement) are represented in shades of grey, and supra salt units are color coded corresponding to the different sequences defined in Figure 3 and section 3. See text for explanation. (a) Regional salt-related map. (b) Close-up of the U2 and U3 unconformities that sealed the pre-HE bedding. (c) Close-up of piercing diaper on the left and sedimentary architecture along a series of two diapiric ridges on the right. (d) Close-up of the diaper termination where pre-HE carbonates are welded together and show a forced fold related to the diaper growth. (e) Close-up of sedimentary architecture showing a progressive onlap of the syn-HE sequence over the pre-HE sequence toward a welded diaper. (f and g) Close-up of the overturned mini-basins.

sedimentation during late-HE times. Such a change in the regional basement geometry would have promoted salt motion in the area.

The salt tectonics map (Figure 5) illustrates an accurate distribution of the Upper Triassic evaporitic sequences throughout the NMU, emphasizing halokinesis and salt-related structures responsible for the development of successive generations of unconformities at the scale of the individual structure.

\subsubsection{Regional Pattern of Folding and Unconformities}

First of all, the NMU is bound by large-scale thrusts, corresponding to the Leitza Fault in the north and the Aralar thrust in the south (Figures 5 and 6). Both are associated with regional (i.e., at NMU-scale) unconformities between the pre-HE and syn-HE deposits as well as internally within the syn-HE sequence between the Lower Cretaceous carbonates-its lateral shaly facies time equivalent-and the Upper Cretaceous turbidites.

The general architecture of the NMU is dominated by a series of large-scale folds with general E-W undulated axes. In detail, these folds are noncylindrical features. Actually, the large anticlinorium with the core of Upper Triassic and pre-HE sequences, located in the central part of the NMU from Uitzi, then Beruete to the Aldudes massif, exhibits sharp azimuthal changes in the fold axes (Figure 5). The synclinal folds are mainly filled and draped by syn-HE Aptian-Albian deposits. This observation is in line with the 

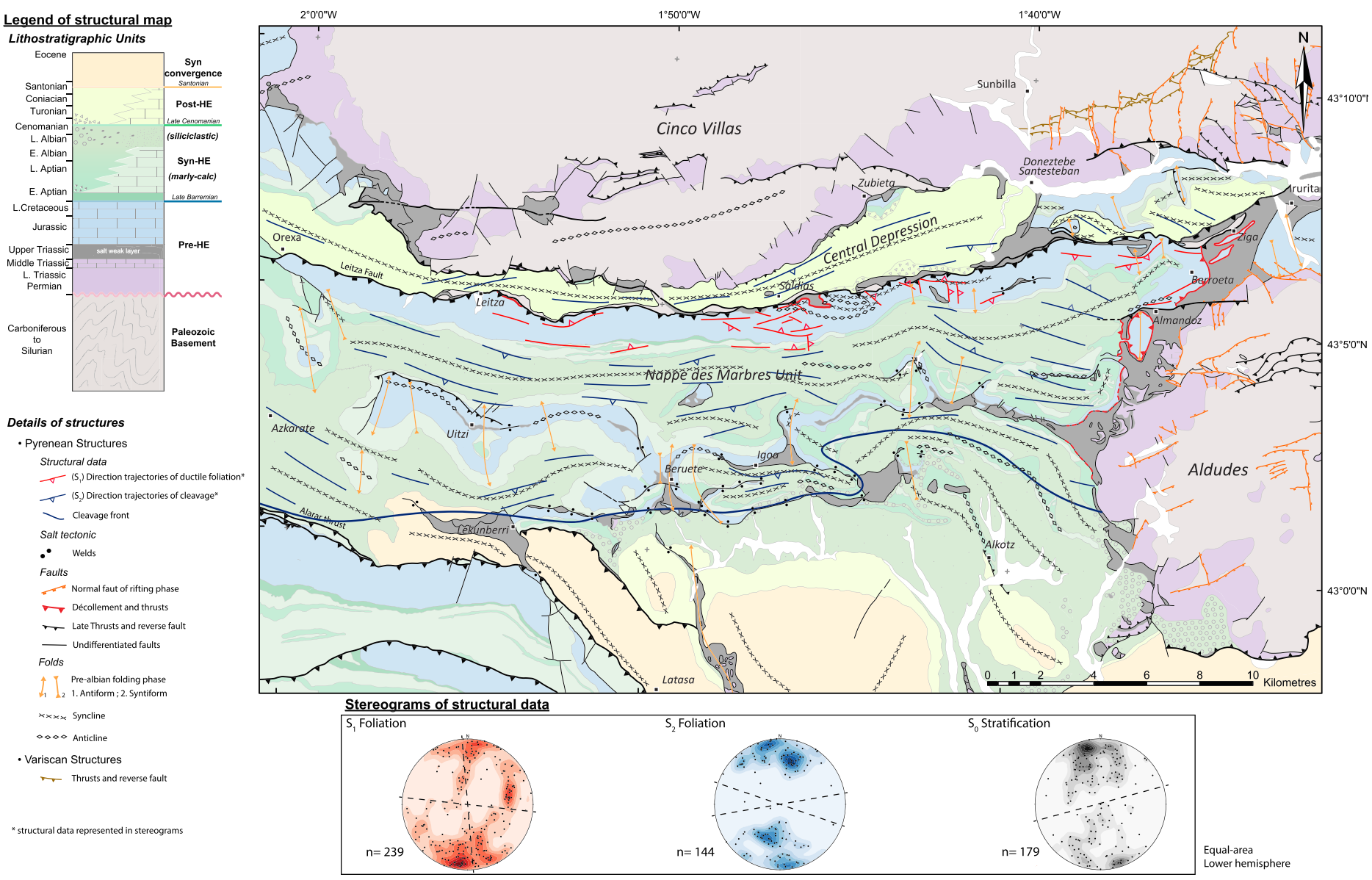

Figure 6. Structural map of the study area showing our structural data and data from Martinez-Torres, 1989. The red and blue stereograms illustrate the strikes and dips of $S_{1}$ and $S_{2}$ foliation planes. The black stereogram illustrates the attitude (strike and dip) of the $S_{0}$ bedding planes. The black dashed line represents the mean $S_{0}$ bedding plane. The green stereogram illustrates the strike and plunge of "alpine" fold axis.

observations of Martinez-Torres (1989) and Ábalos (2016), who emphasized the occurrence of en-echelon folds with NNW-SSE axis sealed by an Albian unconformity (Figure 5). For the authors, these pre-Albian or syn-Albian folds are related to synkinematic salt tectonics along the present-day location of the Leitza fault, with a strike-slip component. This early folding, linked to salt tectonics, may have controlled the observed pre-Albian lateral facies changes and thickness variations across short distances (Figures 2, 3, and 5). These structures suggest that halokinesis began before the Albian period with major facies variations recorded during the early Aptian and may have been influenced by location of sub-salt basement geometry (palaeo-Leitza fault slope).

According to the authors, five major unconformities can be observed in the NMU from the Jurassic to the late Santonian. The first unconformity (U1) of late Tithonian age (Figure 5) is characterized by the wedging out of Lower to Middle Jurassic sediments, eroded, and unconformably overlain by Lower Cretaceous deposits. This configuration may be linked to the onset of halokinesis and to the development of the pre-Albian folds.

The second unconformity (U2), of early Aptian age, should be the equivalent of the top preHE marker as the earliest deposits are coeval with the onset of HE (Figure 5). Capping the Barremian deposits, this unconformity is best observed in the western part of the study area and along the antiformal structure in the central part of the NMU and is well illustrated by toplaps of syn-HE deposits over pre-HE deposits (red arrows in Figure 5).

The main regional unconformity observed in the NMU is Middle Albian in age (U3). This unconformity is marked by a transition from calcareous to siliciclastic sedimentation. Siliciclastic deposits unconformably 

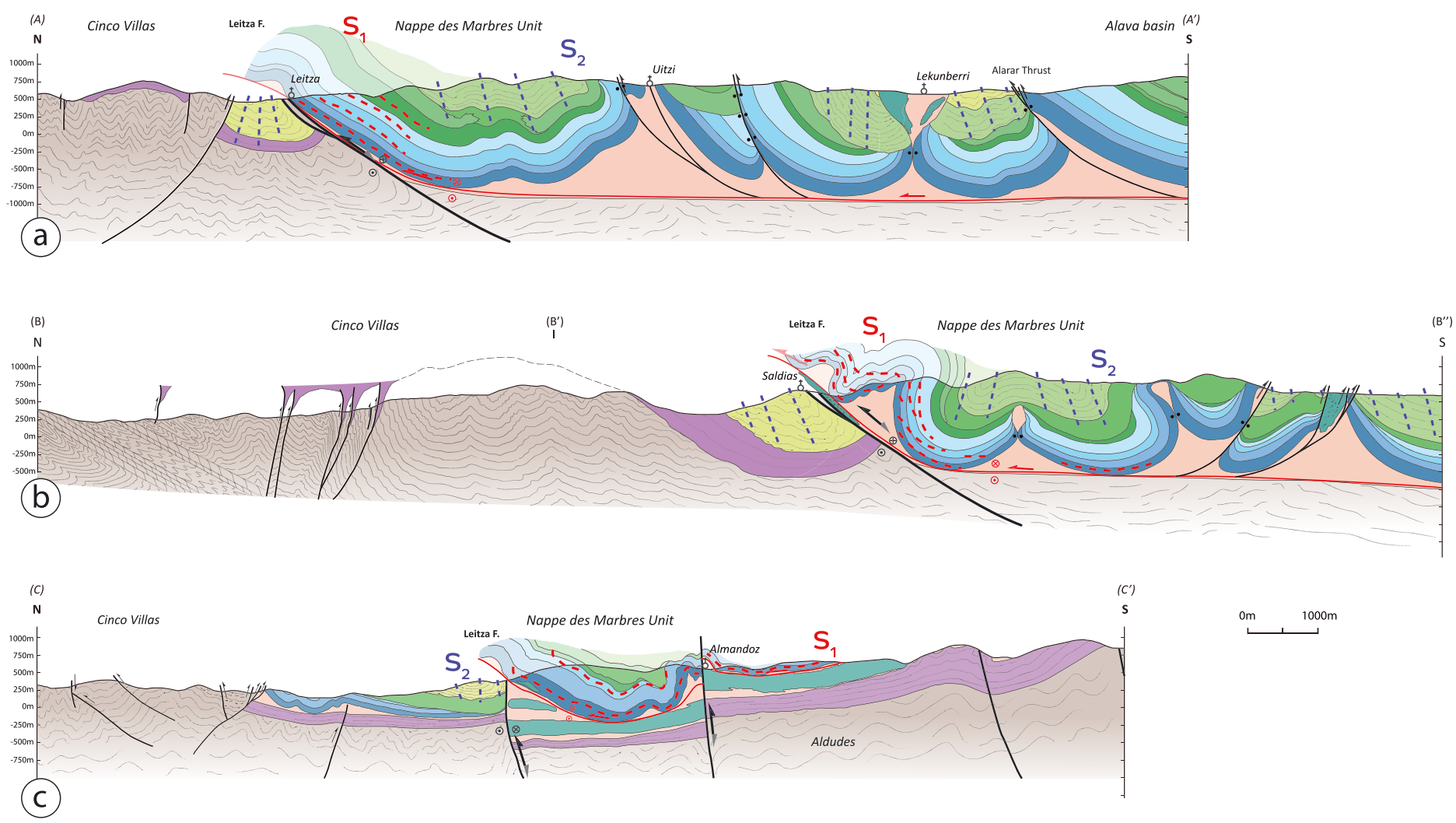

Figure 7. N-S geological cross-sections through the NMU and adjacent areas, from west to east of the study area (see location and legend on the Figure 2).

overlie the lowermost pre-HE supra-salt deposits up to the former syn-HE deposits and develop numerous triple junctions in map view (Figure 5). In the western part of the study area, the spatial distribution of the U2 and U3 unconformities, and their relationships with the lowermost unit are clear. The U2 unconformity sealed the pre-HE bedding highlighted by toplaps (red arrows in Figure 5b), and the Aptian syn-HE are pinched and sealed along the U3 unconformity.

As the map (Figure 5) and sections (Figures 7a and 7b) show, the spatial and temporal relationships of unconformities with lateral conformities into the syn-HE show diachronous filling and local shift of a few fold axes, especially in the central part of the NMU. They actually document sequential filling of mini-basins going along salt-withdrawal synclines (e.g., Callot et al., 2014, 2016; Hudec \& Jackson, 2006, 2009; Hudec et al., 2009 and references therein) separated by diapirs or salt ridges.

The unconformity related to the base post-HE sequence is late Cenomanian in age (U4). It is mainly observed in the eastern part of the Central Depression (Figure 5) where post-HE sequences drape the pre-HE and synHE sequences.

The last unconformity is observed at the base of the synconvergence sequence corresponding to the late Santonian (U5). This unconformity is distinctly observed near Lekunberri, where the synconvergence sequences overlie both the syn-HE and post-HE sequences.

\subsubsection{Evidence for Early (i.e., Jurassic) Salt-Controlled tectonism}

The supra-salt Mesozoic cover of the eastern BCB is affected by piercing diapirs, as observed in different localities (i.e., Oitzi, Beruete, Lekunberri, and Latasa), associated with Upper Triassic rocks (Figures 3, 5, $5 b, 6$, and $7 \mathrm{a}$ and $7 \mathrm{~b}$ ). The first is the Lekunberri diapir that crosscuts both the pre-HE and the synconvergence sequence; the second is the Oitzi diapir that crosscuts a large syncline synkinematically filled by the syn-HE sequence against the Leitza Fault (Figure 5). The last diapir, Latasa, is located in the southern study area. It corresponds to the wider diapir following the Lekunberri diapir and is characterized by the presence of remnants of Lower Triassic stringers wrapped in the Upper Triassic sequence (Figure 5). The observed 
diapirs that cut across the post-HE sediments indicate that salt motion lasted until synorogenic times, as the Maastrichtian layers are also affected by diapirs.

Syn-HE sedimentary architectures related to halokinesis are observed in several places. East of the Beruete diapir associated with ophite stringers, the Aptian pre-HE and syn-HE deposits are overturned along two E-W diapiric salt-walls and are onlapped by Albian syn-HE deposits above U3 (Figure 5c). Between U2 and U3, an onlapping progressive unconformity can be further detailed, demonstrating synkinematic sedimentation.

The same architecture can also be observed in the eastern part of the study area, toward a welded diapir (Figure 5e). This geometry is comparable to the so-called megaflaps classically observed in salt-controlled provinces (Callot et al., 2016; Kergaravat et al., 2017; Rowan et al., 2016). It evidences the synsedimentary folding with final overturning of the pre-HE and syn-HE layers during the growth of the salt structure.

From a facies point of view, diapiric rising surrounded by subsiding synclines develops underfilled settings. The syn-HE Aptian platform carbonates are persistent in the vicinity of diapirs (Urgonian facies), whereas the deeper basin facies accumulated in surrounding subsiding synclines. Control of facies deposits flanking diapirs was already reported for the Mesozoic sedimentary cover of the BCB (Poprawski et al., 2016; Rat, 1988). Syn-HE diapirism is further supported by the occurrence of a forced fold related to the diapiric growth in the central part of the study area. The close-up view in Figure 5d represents the western flank of the salt body, where the Jurassic and the Lower Albian deposits abut it (see the toplaps in Figure 5d), while the late Albian sequence wedges toward the salt body and seems to cap it. This geometry suggests that the salt body corresponds to a diapir, the western flank of which preserved a "conventional" and relatively undisturbed halokinetic sequence (see Poprawski et al. (2016) in the case of the Basque-Cantabrian domain). On the opposite side, the salt body evolved from west to east as a salt weld, laterally terminating in a fold of pre-HE layers. In the same direction, Albian deposits onlap the weld structure and the U2 unconformity. This again calls for a synkinematic gravitational collapse of the diapir's Jurassic roof. The pre-HE sequence is folded here forming a roll-over and is sealed by the syn-HE growth strata. Similarly, Figures $5 \mathrm{e}$ and $5 \mathrm{~g}$ show the folded and truncated pre-HE and early syn-HE sequences sealed by the late Albian above U3. In these cases, the folded sequences are prekinematic and can be interpreted as a megahook structure.

By analogy to their equivalent structure of the Sivas Basin (e.g., Kergaravat et al., 2016, 2017; Legeay et al., 2019), similar tilted mini-basins can also be reported (Figures $5 \mathrm{f}$ and $5 \mathrm{~g}$ ). In these examples, the pre-HE sequence shows both a megahook (Figures $5 \mathrm{~g}$ and $5 \mathrm{~b}$ ) and flaps (Figure $5 \mathrm{c}$ ), associated with syn-HE sedimentary growth.

\subsubsection{Décollement Layer Associated With the Upper Triassic Sequence}

In addition of its impact for salt tectonics strictly spealing, it is regionally well accepted that the Upper Triassic evaporitic represents the main décollement level in the mechanical stratigraphy of the Mesozoic cover deformation as commonly described in the NPZ (e.g., Clerc et al., 2016; Teixell et al., 2018). It is well documented from the eastern termination of the area where NMU klippes occurs over large ophitic bodies above the Aldudes Massif Lower Triassic and Paleozoic basement (Figures 5 and 6). Spatially, this décollement is localized between Lower Jurassic sediments and the ophitic laccolith (Figure 7c). The basement, the Triassic cover, the ophites, and the décollement layer are intersected and deformed by E-W late Pyrenean thrust faults, close to Almandoz (Figures 5, 6, and 7c) suggesting a cover-basement coupling and an out-of-sequence thrusting. At this area corresponding to termination, the NMU is more intensely deformed by decametric folds. This stronger deformation may be due to nearby occurrence of ophitic bodies replacing the salt décollement during the Pyrenean shortening.

\subsection{Regional-Scale Structure of the Eastern Basque-Cantabrian Basin}

The eastern BCB recorded salt tectonics that generated deformation in the Mesozoic sedimentary sequences. However, this region is also affected by (i) a strong deformation in the pre-HE and syn-HE sequence related to HT-ductile deformation and (ii) a smooth regional compressional deformation recorded by a discrete schistosity that requires tectonics.

\subsubsection{Paleozoic Basement Deformation}

The Paleozoic basement shows evidence of post-Lower Triassic compressional deformations, particularly within the Cinco Villas Massif. The southern part of this Massif shows a large anticline of Lower Triassic 
sediments with an E-W striking axis (Figures 6 and 7a and 6b). The wavelength of this fold is the same as that of the Central Depression syncline (Figures 6 and 7), where folding is attributed to the main Pyrenean compressional event. The basement locally overthrusts the Central Depression with top-to-south kinematics, and the vertical Lower Triassic cover is pinched within narrow shortened half-grabens (Figures 7a and 7b). Reverse faults are locally observed in the Aldudes Paleozoic basement (Figure 6).

\subsubsection{Foliations and Schistosity}

The structural study showed that the eastern termination of the Basque-Cantabrian Basin has recorded by two major phases of deformation, associated with two generations of foliation and schistose planes, respectively.

The first one corresponds to foliation planes $\left(\mathrm{S}_{1}\right)$ that have been acquired during a ductile deformational event and are mainly observed in the vicinity of Leitza Fault (Figures 3, 6, and 7). They are only observed within the pre-HE Jurassic to Lower Cretaceous carbonate sediments of the NMU affected by the high thermal metamorphic event (see red foliations in Figures 3, 6, and 7). At map-scale, $S_{1}$ planes show rapid changes in direction and dip, as illustrated on the red stereogram showing dispersed poles of foliations (see red stereogram on the Figure 6). The strikes of these $S_{1}$ planes are oblique to the large folded structure and to the trace of Leitza Fault.

The second deformational event is characterized by the local development of $\mathrm{S}_{2}$ steeply dipping slaty cleavages associated with $\mathrm{N}-\mathrm{S}$ horizontal shortening (see blue stereogram on the Figure 6 ). $\mathrm{S}_{2}$ is only observed in the post-HE sediments of the Central Depression and in the Albian "Black Flysch" syn-HE sediments in the central part of the major synclinal fold of the NMU. In the Central Depression, $S_{2}$ is axial plane of metric to decametric folds, and its general trend is parallel to the strike of the large-scale folds (Figure 6). In the southern limb of the Central Depression, bedding overturned and $\mathrm{S}_{2}$ dips toward the south (Figure 7b). In the NMU, the imprint of the $S_{2}$ is weak. Visible in the Black Flysch, it progressively decreases toward the south and completely disappears south of Lekunberri (Figure 6). In the western and central part of the NMU, $\mathrm{S}_{2}$ strikes parallel to the large-scale fold axes, while in the eastern part it shows an oblique WNW-ESE strike (see blue stereogram in Figure 6).

\subsubsection{Significance of Faults}

The Paleozoic basement of the Eastern BCB, especially in the Aldudes Massif and in the eastern Cinco Villas Massif, is affected by several faults, most of which correspond to former normal faults (orange in Figure 6). These faults cut former Variscan top-to-north thrusts (brown in Figure 6) and the Paleozoic basement with its unconformable Lower Triassic sedimentary cover. They attest for several extensional events recorded during the Triassic, Jurassic, and Cretaceous, before the main Pyrenean compression. In the Cinco Villas Massif, most of these faults strike N-S, delimiting blocks tilted toward the east, while the Aldudes Massif is affected by ENE-WSW to E-W striking normal faults (Figure 6). These structures were not reactivated during the Pyrenean orogeny. However, the basement is also cut by some reverse faults, probably reactivating former normal faults (represented in black in Figure 6). Indeed, these E-W striking reverse faults systematically bound Lower Triassic sediments deposited in former grabens (Figures 6 and $7 \mathrm{~b}$ ).

The NMU is mostly affected by several welds and some small-scale reverse faults, probably active during the Pyrenean convergence (represented in black on Figure 6). These welds with variable directions are mostly observed in anticlinoriums with pre-HE Jurassic and Upper Triassic evaporitic cores. The rigid behavior of ophite bodies, sedimentary packages adjacent to diapirs, and salt walls may also favor the localization of deformation. We assume that these faults and welds are connected in depth to the Upper Triassic evaporitic sequence, acting as a décollement. The main thrusts observed in the NMU are located to the south. These thrusts that limited the south margin of the basin show top-to-north kinematics, such as the Alarar thrust, (Figure 6).

To the north, the NMU is bounded by the Leitza Fault. As previously described, this fault is considered as a major structure between the Central Depression and the NMU (Figure 6). This fault is associated with several ophites bodies, Upper Triassic sediments, and basement lenses (Figures 6 and 7). The deeper parts of the NMU are exposed along this structure that corresponds to a limit between two domains with different modes of deformation. Indeed, it separates the NMU affected by a $S_{1}$ ductile foliation, locally by $S_{2}$ cleavage and HTLP metamorphism, from the Central Depression affected only by folding associated with $\mathrm{S}_{2}$ slaty cleavage and made of nonmetamorphic sediments. 

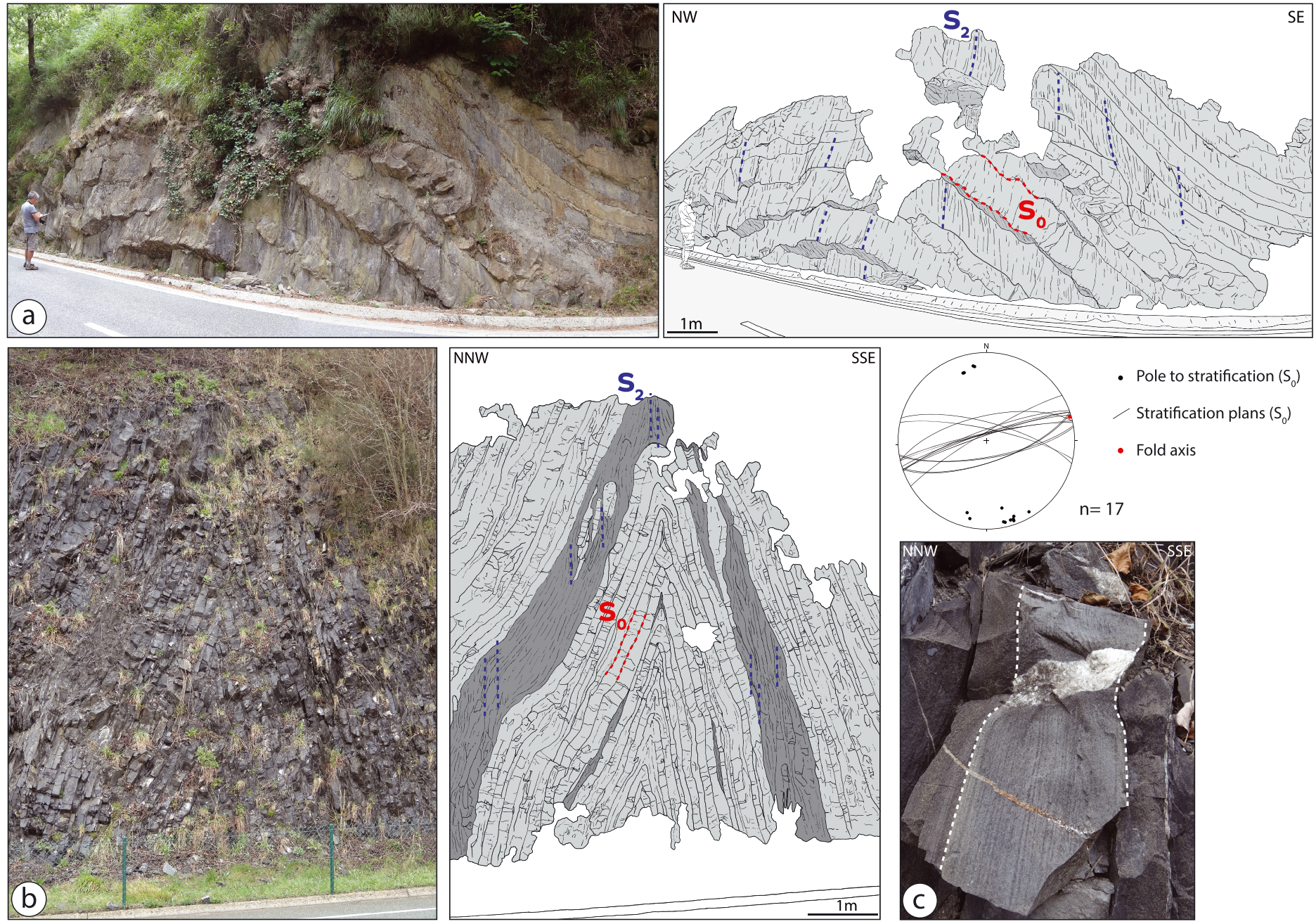

Figure 8. Field photographs and interpretations of compressional structures observed in the Central Depression. (a) A gentle anticlinal fold with an axis gently plunging to the $\mathrm{E}$ and the coeval development of a pronounced $\mathrm{S}_{2}$ foliation, axial plane of the fold, located in the eastern part of the Central Depression ( $43^{\circ} 5^{\prime}$ $12.102^{\prime \prime} \mathrm{N}, 1^{\circ} 47^{\prime} 54.823^{\prime \prime} \mathrm{W}$ ). (b) An angular upright anticlinal fold in the western part of the Central Depression. $\mathrm{S}_{2}$ is slightly developed in marly layers. The stereogram represents structural data in this fold $\left(43^{\circ} 5^{\prime} 14.885^{\prime \prime} \mathrm{N}, 1^{\circ} 55^{\prime} 25.781^{\prime \prime} \mathrm{W}\right)$. (c) Zoom on a calcareous layer of the previous fold (fig b) that was boudinaged with coeval development and slight rotation of a calcitic vein in the boudin neck.

\subsection{Field Evidence of Superposed Deformations in the NMU and Adjacent Domains 4.3.1. The Central Depression}

The Central Depression is only affected by the second deformation phase related to the $\mathrm{S}_{2}$ slaty cleavage that is clearly associated with N-S horizontal shortening affecting Upper Cretaceous sediments. Post-HE sediments are affected by $\mathrm{S}_{2}$, axial plane of E-W striking folds displaying different wavelengths from metric-scale to basin-scale (Figure 8). The eastern Central Depression is $3-4 \mathrm{~km}$ wide and slightly overthrusts the Cinco Villas Massif or locally simply unconformably overlies the basement. In its eastern part, the post-HE sediments are folded by numerous decametric gentle folds with $\mathrm{S}_{2}$ as their axial plane (Figure 8a). The western and central parts of the Central Depression are only 1-2 km wide and are overthrust by the Cinco Villas Massif. In this domain, numerous decametric acute folds with vertical axial planes and associated $\mathrm{S}_{2}$ cleavage are mostly expressed in marly intercalations (Figure 8b). Many competent layers are affected by boudinage, with the development and slight rotation of calcitic veins in boudin necks (Figure 8c). Close to Leitza fault, decimeter-thick competent layers within the calcareous flysch of the Central Depression show many late shears with top-to-north shear directions. In the Central Depression $\mathrm{S}_{2}$ cleavage overall dips moderately to steeply to the south, indicating a large synclinal fold facing to the north (Figure 6). In the eastern 

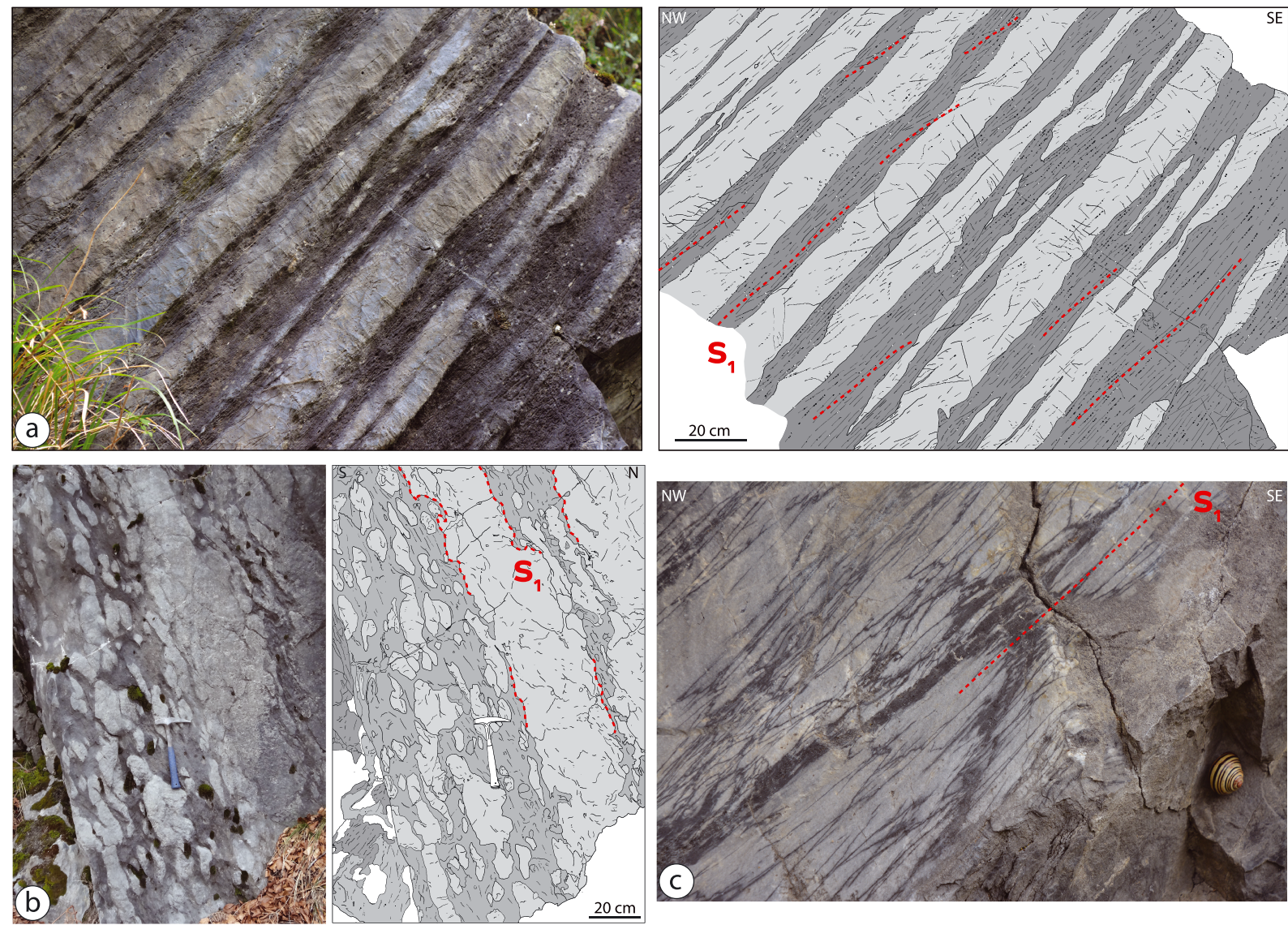

Figure 9. Field photographs and interpretations of geological structures developed during an extensional ductile deformation in the NMB. (a) Alternation of middle Jurassic limestones and marls metamorphosed and boudinaged during the extensional event. $\mathrm{S}_{1}$ is parallel to $\mathrm{S}_{0}$ so the main foliation plane is called $\mathrm{S}_{1}$. The $\mathrm{S}_{1}$ plane was crosscut by an understated $\mathrm{S}_{2}$ foliation during the compressional event $\left(43^{\circ} 4^{\prime} 32.995^{\prime} \mathrm{N}, 1^{\circ} 46^{\prime} 26.317^{\prime \prime} \mathrm{W}\right)$. (b) Alternation of limestone and breccia affected by ductile deformation $\left(43^{\circ} 4^{\prime} 19.747^{\prime \prime} \mathrm{N}, 1^{\circ} 47^{\prime} 38.515^{\prime \prime} \mathrm{W}\right)$. (c) $\mathrm{S}_{0}$ bedding planes completely transposed by an $\mathrm{S}_{1}$ foliation during an extensional ductile event ( $43^{\circ} 4^{\prime}$ $\left.28.596^{\prime \prime} \mathrm{N}, 1^{\circ} 46^{\prime} 18.821^{\prime \prime} \mathrm{W}\right)$.

termination of the Central Depression, near Ziga, the axes of folds associated with $\mathrm{S}_{2}$ cleavage in post-HE sediments are oblique to the direction of Leitza fault.

\subsubsection{The NMU}

The NMU is associated with different phases of deformation, starting with early salt tectonics, diapirism, and internal unconformities, followed by $S_{1}$ ductile foliation and finally the $S_{2}$ slaty cleavage less frequently visible that in the Central Depression. The first ductile foliation planes $\left(\mathrm{S}_{1}\right)$ are only observed in the northern NMU within the Jurassic to Lower Cretaceous carbonate sediments, close to Leitza Fault (see red foliations in Figures 3 and 6). These ductile foliation planes are most often parallel to the original bedding (Figure 9) and in the field, $S_{0}$ and $S_{1}$ are often impossible to discriminate. This ductile deformation is more intense near Saldias (see location on Figure 6) and tends to decrease eastward and westward. Near Leitza, $\mathrm{S}_{1}$ foliations are barely represented, only the bedding is observed. Stretching lineations are rarely observed in the field and are thus not represented on the structural map.

Beside intense small-scale folding and ductile foliation development, marbles show evidence of boudinage. Middle Jurassic carbonates and marl alternations display local pinch-and-swell structures, where $S_{1}$ is slightly oblique on bedding. (Figure 9a). A Lower Cretaceous carbonate breccia layer intercalated with metamorphosed limestone shows evidence of this first stage of deformation. Lobate clasts are ductily stretched parallel to the regional foliation in thick beds of carbonates nearby (Figure 9b). In Oxfordian to Tithonian marbles, the $S_{0}$ bedding may be completely transposed into the $S_{1}$ foliation (Figure $9 \mathrm{c}$ ). In few places, centimeter- to decimeter-scale ductile folds affect $S_{0}$ bedding planes. This foliation indicating an intense ductile 

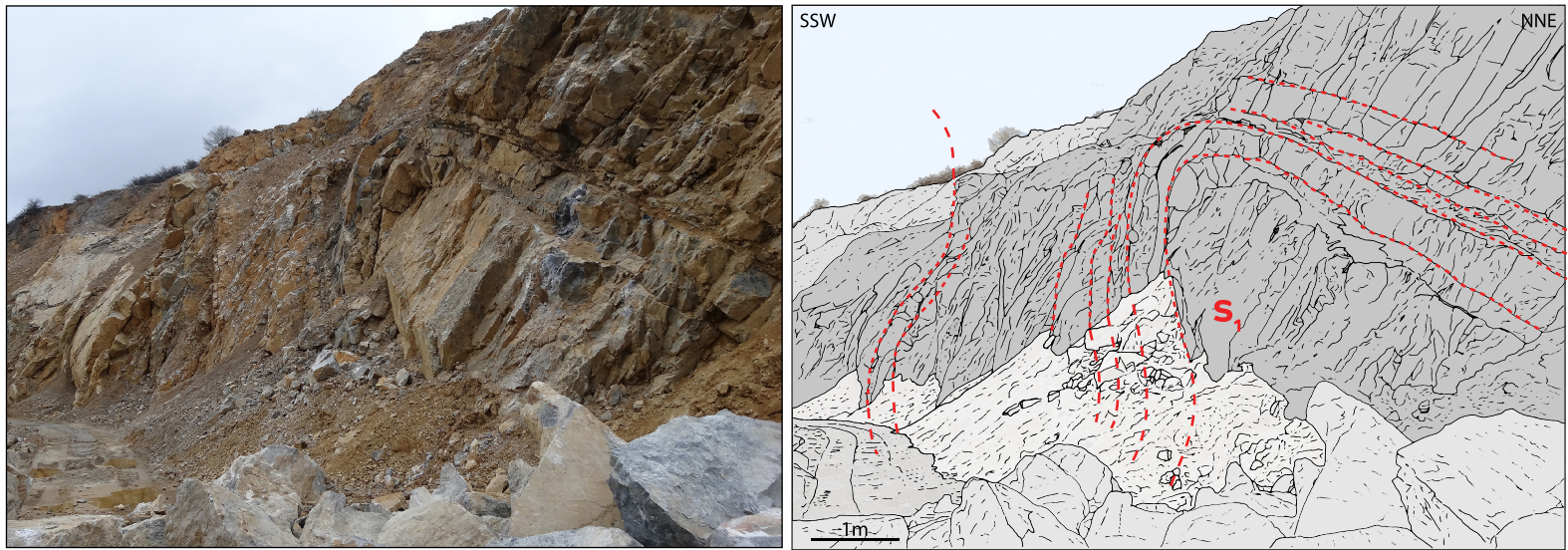

Figure 10. Field photograph and interpretation of decametric E-W open disharmonic folds in the Almandoz quarry, close to an ophitic laccolite. This area is marked by intense compressional deformation $\left(43^{\circ} 5^{\prime} 43.865^{\prime \prime} \mathrm{N}, 1^{\circ} 36^{\prime} 22.979^{\prime \prime} \mathrm{W}\right)$.

deformation occurs exclusively in pre-HE sediments and is only localized at the base of the NMU, close to Leitza Fault.

Contrarily to the Central Depression, the second phase of deformation associated with the $\mathrm{S}_{2}$ slaty cleavage is less frequently visible and only observed in the syn-HE Albian "black flysch" sediments. $\mathrm{S}_{2}$ cleavage does not develop within pre-HE sediments located at the base of the NMU.

Toward the south, $\mathrm{S}_{2}$ cleavage intensity progressively decreases and is limited in space by the cleavage front (Figure 6). This cleavage is completely absent to the south of Beruete and only large-scale folds are observed near Alkotz (Figure 6) with NW-SE striking axes (Figure 6). $S_{2}$ cleavage has been developed widely in the shales and flysch sequences of the NMU; however, the associated deformation is weaker than in the Central Depression, suggesting that the Pyrenean shortening only weakly affected this region. The most substantial compressional deformation in the NMU is located in its eastern termination, near Almandoz, close to the Aldudes Massif in the vicinity of large ophitic laccoliths. Indeed, the Almandoz quarry exhibits decametric folds with E-W to ENE-WSW striking axes, corresponding to open disharmonic noncylindrical folds with gently plunging fold axis (Figure 10). These disharmonic folds affect the $\mathrm{S}_{1}$ foliation parallel to bedding, without the coeval development of a $S_{2}$ cleavage or foliation. These folds are located in the vicinity of a reverse fault with the same strike. This reverse fault marks the contact between folded pre-HE sediments and the large ophitic laccoliths (Figures 6 and 7c). The presence of these folds suggests a more intense N-S horizontal shortening there, only localized in the eastern part of the NMU.

\subsubsection{Evidences of Décollement Layer at the base of the NMU}

It is commonly accepted that the Upper Triassic layer corresponds to an efficient décollement layer in the BCB (Bodego et al., 2018; Carola et al., 2015; Tavani et al., 2013). This décollement layer corresponding to the interface between the Upper Triassic and Jurassic sediments outcrops in the eastern BCB. In fact, in the eastern part of the NMU and in particular to the south of Almandoz (Figure 6), a huge zone of a massive breccia occurs at the base of the Lower Jurassic series (Figure 11a), close to the contact with the Upper Triassic sediments mainly composed by versicolor clays. Clasts in the breccia are polygenic and show variable sizes comprised between few millimeters to meters (Figure 11). The origin of clasts changes from layer to layer, some containing versicolor clasts (red, yellow, and purple) of different sizes and others only clasts of grey carbonates (Figure 11b). The origin of this breccia is not obvious and may have a sedimentary or a tectonic origin. We interpret this breccia as a tectonic breccia because it displays the aspect of a "tectonic mélange” with Upper Triassic and Lower Jurassic sedimentary clasts and without clear internal organization. In detail, the breccia shows clasts of different geometries with angular shapes, with sharp or more rounded shapes. These clasts are contained in a very fine-grained matrix locally recrystallized (Figure 11c). Numerous clasts show an internal layering that probably corresponds to $\mathrm{S}_{1}$ foliation. Such features allow us to interpret this formation as a layered tectonic breccia localized at the base of the Lower Jurassic series. This tectonic breccia widely affects the Upper Triassic and the lower part of Lower Jurassic 

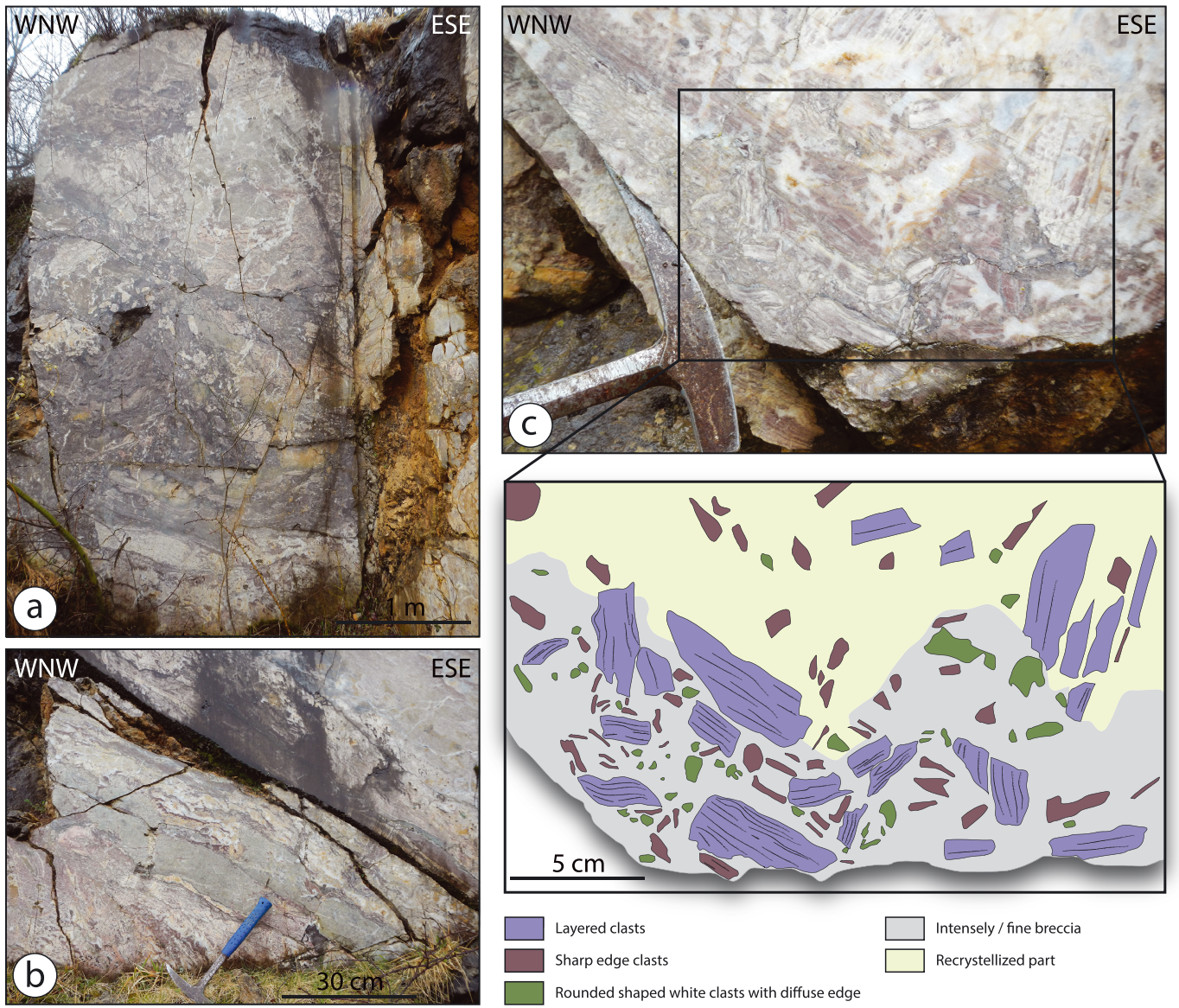

Rounded shaped white clasts with diffuse edge

Figure 11. Field photograph and interpretation of the tectonic breccia located at the base of the eastern part of NMU in the Jurassic marble. (a) View of the part of breccia in the abandoned carry that exposed Lower Jurassic formation $\left(43^{\circ} 5^{\prime} 7.83^{\prime \prime} \mathrm{N}\right.$, $1^{\circ} 37^{\prime} 0.22^{\prime \prime} \mathrm{W}$ ). (b) Detail of the breccia showing an alternation of a versicolor clast layer and a more massive layer composed of grey carbonates $\left(43^{\circ} 5^{\prime} 7.83^{\prime \prime} \mathrm{N}, 1^{\circ} 37^{\prime} 0.03^{\prime \prime} \mathrm{W}\right)$. (c) Detail of the breccia with detail of the different clasts and the cement. $\left(43^{\circ} 5^{\prime} 7.91^{\prime \prime} \mathrm{N}, 1^{\circ} 37^{\prime} 0.54^{\prime \prime} \mathrm{W}\right)$.

sediments, suggesting a décollement level, localized to the base of Lower Jurassic and represented as red lines in the structural map (Figure 6).

\section{New Insights on the Thermal Structure of the NMU With Raman Spectroscopy}

\subsection{Raman Spectroscopy of Carbonaceous Materials: Analytical Method}

RSCMs (Beyssac, Goffé, et al., 2002; Lahfid et al., 2010) was used on 89 samples to characterize the distribution of the maximum recorded temperature $\left(T_{\mathrm{RSCM}}\right)$ in the study area. This analytical method characterizes the structural evolution of carbonaceous material (CM), which reflects the transformation from disordered to well-ordered CM during metamorphism (Wopenka \& Pasteris, 1993). The irreversible polymerization and reorganization of these materials is reflected in their Raman spectrum by the decreasing width of the graphite $\mathrm{G}$ band and gradual disappearance of the defect bands, first D3 and D4, then D1 and D2. The Raman spectrum of well-ordered CM (perfect graphite) contains only the G band. The link between increasing graphitization and temperature was quantified, resulting in a tool for determining peak temperatures attained by metamorphic rocks (Beyssac, Goffé, et al., 2002). Since graphitization is an irreversible process, the RSCM method gives the peak metamorphic temperatures (Beyssac, Goffé, et al., 2002; Pasteris \& Wopenka, 1991). This is the basis of the RSCM geothermometer, which was calibrated in the range of 330 to $650^{\circ} \mathrm{C}$ by Beyssac, Goffé, et al. (2002) and extended to the range of 200 to $320^{\circ} \mathrm{C}$ by Lahfid et al. (2010). 
In this study, we used these two calibrations to estimate paleotemperatures in marbles and pelitic metasedimentary rocks from the Paleozoic to Upper Cretaceous series in the study area (NMU + Central Depression + Variscan basement). Raman analyses were performed using a Renishaw (Wotton-under-Edge, UK) InVIA Reflex microspectrometer at the BRGM in Orléans. Before each session, the spectrometer was calibrated with a silicon standard. The light source was a 514-nm Spectra Physics argon laser. The output laser power is around $20 \mathrm{~mW}$, but only about $1 \mathrm{~mW}$ reached the surface sample through the DMLM Leica (Wetzlar, Germany) microscope with a 100- $\mu \mathrm{m}$ objective (NAD 0.90). Edge filters eliminated the Rayleigh diffusion, and the Raman light was dispersed using an 1,800-g/mm grating before being analyzed by a Peltier-cooled RENCAM CCD detector. Measurements were performed in situ on polished thin sections cut normal to the foliation and parallel to the stretching lineation ( $X Z$ structural planes), when L1 was visible. To avoid the effect of polishing on the CM structural state, the analyzed CM particles analyzed were placed below a transparent adjacent mineral, usually calcite or quartz (Beyssac, Rouzaud, et al., 2002; Pasteris, 1989; Scharf et al., 2013). Eleven to 18 points were measured for each sample, with 10 to 15 accumulations of 10-s acquisition periods. The measured Raman spectra of the CM were decomposed for all Raman peaks of carbon by using PeakFit (v4.06) software (Systat Software Inc ${ }^{\circledR}$ ). All results are presented in Table S1 in the supporting information and Figure 12.

\subsection{Distribution of $T_{\mathrm{RSCM}}$ and Thermal Variations Within the Study Area}

The sample distribution was designed to quantify $T_{\mathrm{RSCM}}$ within all the structural units (e.g., NMU, Central Depression, and Variscan basement) and across potential gradients or gaps, with a view to characterizing the spatial distribution of the HT-LP Cretaceous metamorphism (Figure 12a). RSCM results show that temperatures range from less than $200^{\circ} \mathrm{C}$ up to $578^{\circ} \mathrm{C}$ (Table S1). The minimum values $<200^{\circ} \mathrm{C}$ cannot be more precisely constrained as they fall outside the temperature range indicated for using the method developed by Lahfid et al. (2010), which is between 200 and $320^{\circ} \mathrm{C}$.

First, the RSCM method was used on samples from the Variscan basements and associated Paleozoic sedimentary covers. Four samples from the Cinco Villas Massif were analyzed and indicate temperatures of $353 \pm 6^{\circ} \mathrm{C}, 363 \pm 5^{\circ} \mathrm{C}$, and $424 \pm 14^{\circ} \mathrm{C}$ for samples from the south of the Massif and a temperature of 481 $\pm 19^{\circ} \mathrm{C}$ for a sample from the central part of the Massif. The higher temperature along the southern edge of the Massif is probably linked to the occurrence of a nearby ophitic intrusion. The temperature measured in the central part of the Cinco Villas Massif can be correlated with the Permian Aya plutonic intrusion and associated metamorphism (Pesquera \& Velasco, 1988). Only one sample from the Aldudes Massif was analyzed, and it indicates a temperature of $324 \pm 9^{\circ} \mathrm{C}$. Temperatures measured between $324 \pm 9^{\circ} \mathrm{C}$ to $363 \pm 5^{\circ}$ $\mathrm{C}$ in the Variscan basements correspond to the low-grade metamorphism (greenschist facies) that can be attributed either to the Variscan or the Pyrenean metamorphism.

Several samples were collected north of Leitza Fault, in the post-HE sediments of the Central Depression and in the unconformable non-metamorphic Mesozoic sediments overlying the basement. Eight samples were analyzed from the central and eastern parts of the Central Depression analyzed and resulting temperatures are all below $200^{\circ} \mathrm{C}$. Further west, the Calcareous Flysch gave temperatures of $281 \pm 9^{\circ} \mathrm{C}$ and $273 \pm 10^{\circ} \mathrm{C}$, while the Mesozoic sediments gave a temperature of $320 \pm 20^{\circ} \mathrm{C}$. This shows that the post-HE sediments of the Central Depression are not affected by HT-LP metamorphism. Higher temperatures in the west of the Central Depression indicate that the base of this sedimentary basin probably deepens eastward. The pre-HE sedimentary cover in the southwest margin of the Cinco Villas Massif is only slightly affected by the Cretaceous metamorphic event.

Several samples were collected from the basement shreds and associated Upper Triassic sediments that crop out along the Leitza Fault. Two analyzed basement samples yield temperatures of $363 \pm 7^{\circ} \mathrm{C}$ and $312 \pm 16^{\circ} \mathrm{C}$, and one sample from an Upper Triassic cellular dolomite yields a temperature of $270 \pm 27^{\circ} \mathrm{C}$. The temperatures obtained for the Variscan siltites corroborate the temperatures obtained for the Cinco Villas Massif further north, and the Triassic cellular dolomite does not seem to be affected by HT-LP metamorphism.

Most of the samples were collected south of Leitza Fault within the NMU, with a tighter mesh size to better constrain distribution of metamorphism within this unit. RSCM results indicate temperatures higher than $500^{\circ} \mathrm{C}$ along the Leitza Fault in pre-HE and syn-HE sediments. The maximum temperatures are found in the Albian flysch and Lower Cretaceous marbles of the central part of the NMU, around Saldias. 

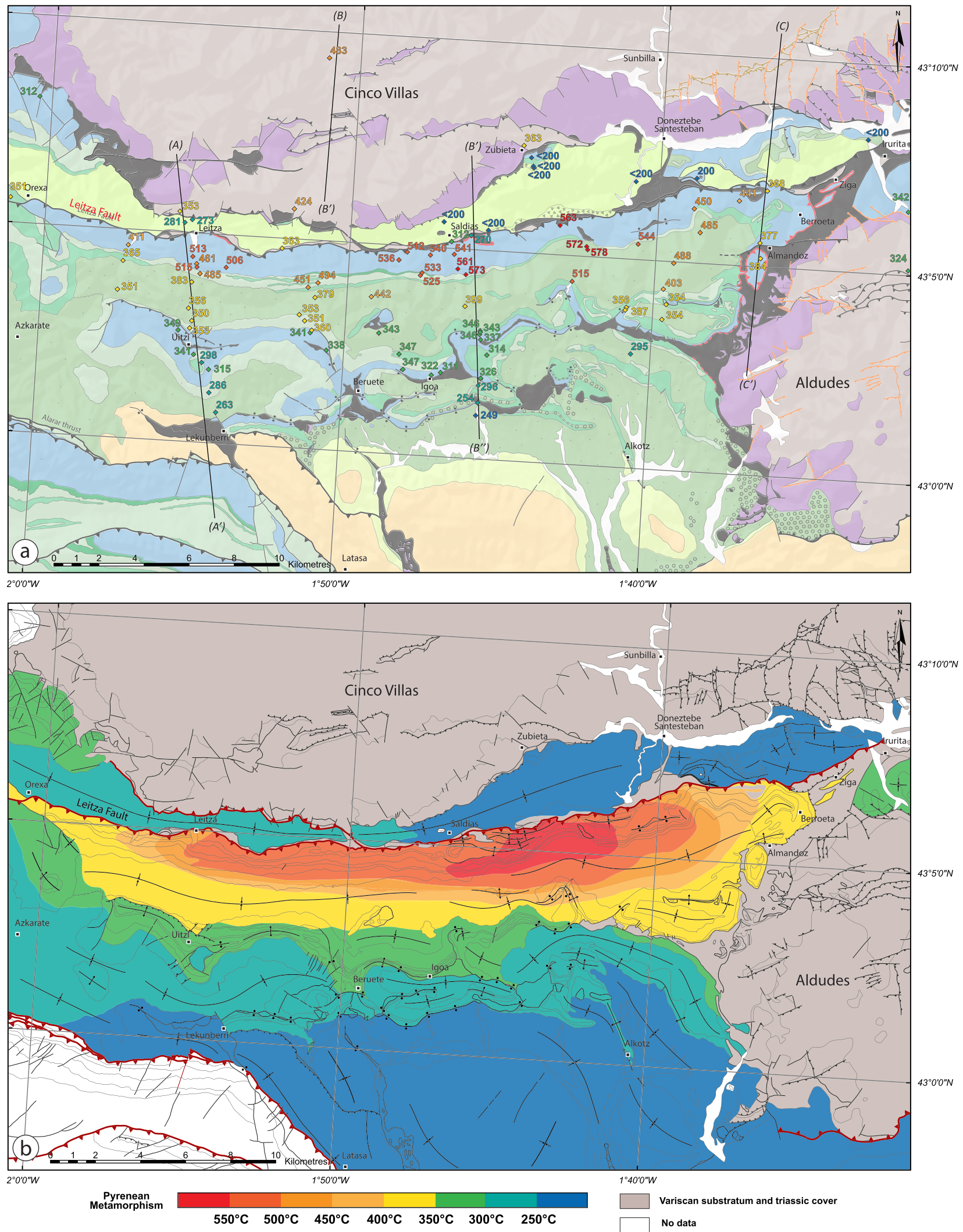

Figure 12. Maps of Raman spectroscopy of carbonaceous material (RSCM) peak temperatures obtained and associated isotherms in the study area. (a) Geological map with sample locations and the RSCM peak temperature values obtained in this study. (b) Isometamorphic map of the Nappe des Marbres Unit representing the current state of the basin associated with RSCM peak temperatures recorded by the rocks during the Pyrenean metamorphic event. 
Temperatures ranged from $572 \pm 20^{\circ} \mathrm{C}$ to $578 \pm 29^{\circ} \mathrm{C}$ (Figure 12a). Laterally, eastward and westward, measured $T_{\mathrm{RSCM}}$ decreases within a single lithostratigraphic unit. We observe a rapid eastward temperature decrease of approximately $100^{\circ} \mathrm{C}$ within a few kilometers (Figure 12a). Temperature values in the eastern part of the NMU are lower than in the central part of the unit, despite the occurrence of a lherzolite body cropping out at Ziga (DeFelipe et al., 2017; Mendia and Ibarguchi, 1991). A strong temperature decrease is also observed toward the south. For example, south of Saldias, $T_{\mathrm{RSCM}}$ decreases from $550^{\circ} \mathrm{C}$ near Leitza Fault to $400^{\circ} \mathrm{C}$ in the Albo-Cenomanian flysch and down to $340^{\circ} \mathrm{C}$ to the south, on the Jurassic antiform corresponding to a salt ridge (Figure 12a).

South of this salt ridge, the temperature decrease is less significant and $T_{\mathrm{RSCM}}$ values range from $296 \pm 9^{\circ} \mathrm{C}$ to $249 \pm 10^{\circ} \mathrm{C}$, for the southernmost value. This dense grid distribution of $T_{\mathrm{RSCM}}$ values obtained by the RSCM method can then be used to build a map of isometamorphic zones within the NMU (Figure 12b). This map is, of the first order, compatible with the metamorphic map obtained from the conventional petrological study by Martinez-Torres (1989), but our data are more precise.

The map in Figure $12 \mathrm{~b}$ reflects the spatial distribution of HT-LP metamorphism within the basin. First, there is a strong contrast of $T_{\mathrm{RSCM}}$ between the NMU and the Central Depression to the north of the Leitza fault, with a temperature gap exceeding $350^{\circ} \mathrm{C}$ (Figure 12a). So, the Leitza Fault separates two distinct units, an HT-LP metamorphic unit to the south and a nonmetamorphic unit to the north, which is consistent with field observations. Secondly, E-W and N-S lateral thermal gradients occur in the NMU with maximum temperatures localized along the Leitza Fault.

\section{Interpretations}

\subsection{Relation Between Structures and Spatial Temperature Distribution}

The relationship between the current structure and the paleotemperature distribution provides important information on the evolution of the NMU. One of the most obvious observations is that the maximum temperatures measured are not related to the stratigraphic age of rocks in the NMU basin. The maximum temperatures are recorded near the Leitza Fault near Saldias and they decrease eastward, westward, and southward from there, irrespective of the stratigraphic ages and across the main folds. To show the implications of this 3-D map for the relation between the present-day structure and the HT-LP metamorphism, we plotted measured $T_{\mathrm{RSCM}}$ on the geological cross sections and associated temperatures versus distance graphs (Figure 13). The graphs clearly show a gradual temperature decrease toward the south with rather simple gradients, much less complex than the folded structure, showing without ambiguity that the thermal event was recorded after a large part of the folding had occurred. Within a single stratigraphic level, especially the pre-HE series, $T_{\mathrm{RSCM}}$ values show a clear decrease through the large-scale syncline. In fact, on the northern side of this syncline along Leitza Fault, $\mathrm{T}_{\mathrm{RSCM}}$ exhibit values of around $550^{\circ} \mathrm{C}$, whereas on its southern side, $T_{\mathrm{RSCM}}$ values are around $350^{\circ} \mathrm{C}$ within the Early Cretaceous layers (Figures $13 \mathrm{a}$ and 13b). The temperature then decreases down to $200^{\circ} \mathrm{C}$ over a few kilometers in the same level. This is less obvious in the eastern part of the NMU because of lack of data, but temperatures also decreased toward the south irrespective of the stratigraphic age. Similar observations can be made laterally, parallel to the Leitza Fault (Figure 13c). This 550 to $250^{\circ} \mathrm{C}$ map of $T_{\mathrm{RSCM}}$, and the cross section, shows that the isograds are not folded with the bedding, or at least are less intensely folded than bedding and are thus oblique on the present-day architecture of the NMU (i.e. the large-scale folding). This suggests that these folds were partly formed before the thermal overprint. Had the thermal overprint been recorded before folding, the anticline would have corresponded to higher temperatures and synclines to lower temperatures, which is not the case.

The 3D block diagram in Figure 14 shows this configuration with the geological map and cross-sections associated with the isograds of HT-LP metamorphism. The current spatial distribution of $T_{\mathrm{RSCM}}$ during HT-LP metamorphism in the NMU is heterogeneous, with lateral gradients and a strong thermal gap across the Leitza Fault. The highest $T_{\mathrm{RSCM}}$ are localized in the central northern part of the basin, nearing the Leitza Fault, in the pre-HE sediments (Jurassic to Cretaceous marbles and Albian black flyschs) with temperatures exceeding $570^{\circ} \mathrm{C}$ (Figures 12-14). Laterally (from east to west, and from north to south), $T_{\mathrm{RSCM}}$ rapidly decrease around to 350 to $300^{\circ} \mathrm{C}$ and become homogeneous with temperatures lower than $250^{\circ} \mathrm{C}$ (Figures 12-14). The metamorphic distribution is difficult to characterize further west in the $\mathrm{BCB}$, because 

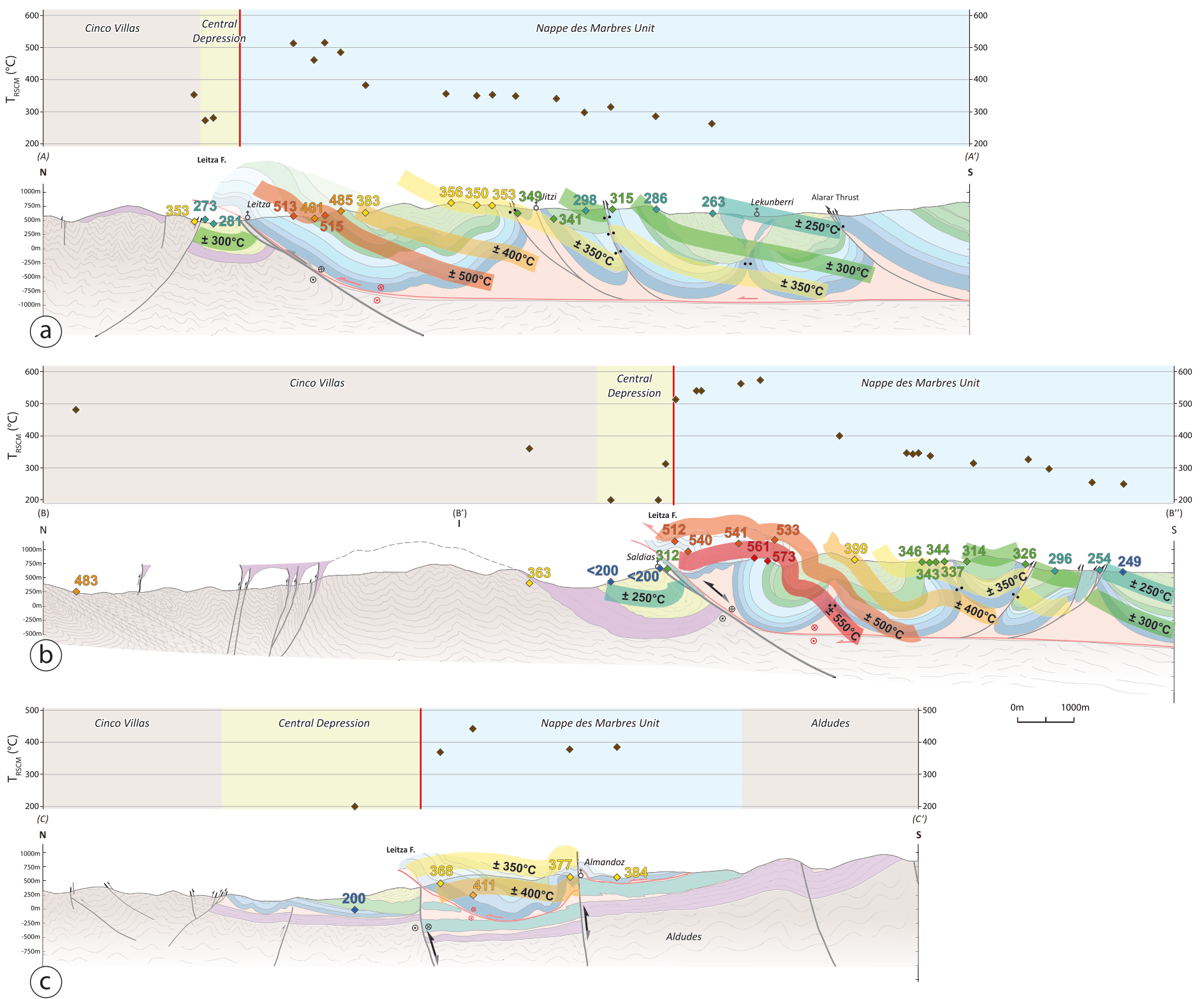

Figure 13. N-S geological cross sections through the Nappe des Marbres Unit associated with $T_{\mathrm{RSCM}}$ data and relevant graph ( $T_{\mathrm{RSCM}}$ versus distance; see location and legend on Figure 2). The isotherms were plotted with a margin of error.

of lack of data and of outcrops of Jurassic to Cretaceous sediments associated with the HT-LP metamorphic event. Laterally, in the southern margin of the Biscay syncline, vitrinite reflectance measured in drill holes reveals a thermal overprint with reflectance of 6-7\% (Robert, 1971), corresponding to temperatures higher than $350^{\circ} \mathrm{C}$ (e.g., Ferreiro Mählmann \& Le Bayon, 2016 and references therein). These relatively high temperatures are also present in the Biscay folds (western continuity of the Nappe des Marbres syncline) and the Lower Cretaceous series to the top of the Albian sediments or the lower part of the Cenomanian series (Robert, 1971), which is the westward extension of the NMU. Both the E-W and N-S lateral gradients observed in the NMU correspond to a gradual temperature decrease, but there is no evidence of the large structures that may have controlled these thermal gradients, unlike along the Leitza fault that sharply limits the metamorphic domain and probably corresponds to the sole thrust of the NMU. The thermal gradients obtained with $T_{\mathrm{RSCM}}$ show that isograds related to HT-LP metamorphism intersect geological structures in the NMU (Figures 13 and 14). Effectively, isograds seem to have been moderately 


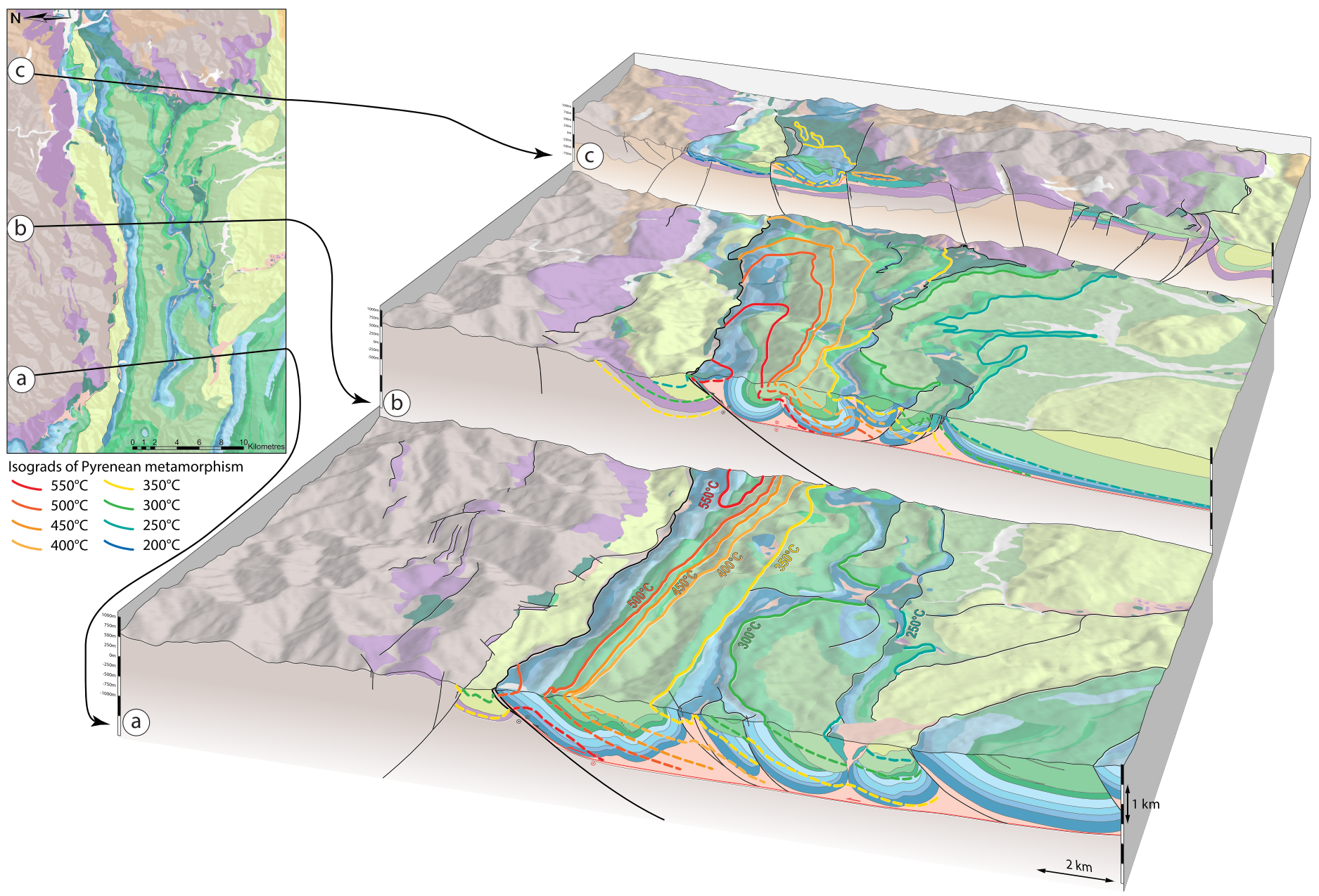

Figure 14. 3-D block diagram of the Nappe des Marbres Unit (NMU) showing the relationship between the thermal distribution and the geological structures.

affected by late compressional deformations (Figures 13 and 14). These observations suggest that the metamorphic event is younger that the main development of folds in the NMU. Even though the age and geographic span of metamorphism is debated, it is dated at $81 \pm 3$ to $101 \pm 16 \mathrm{Ma}$ (Albarède \& MichardVitrac, 1978a,b; Montigny et al., 1986), corresponding to the late Albian to early Campanian. Yet the onset of convergence and contractional deformation in the Pyrenean and Basque Cantabrian belts is considered as Santonian ( 84 Ma; García-Senz, 2002; Garrido-Megias \& Rios Aragues, 1972; McClay et al., 2004; Mouthereau et al., 2014; Muñoz, 1992; Olivet, 1996; Roest \& Srivastava, 1991; Rosenbaum et al., 2002; Teixell, 1998; Vergés et al., 1995; Vergés \& García-Senz, 2001). Then, the major compressional phase occurred in Eocene-Oligocene Epochs (Muñoz, 1992, 2002; Mouthereau et al., 2014; Vergés et al., 2002). This chronology and the geometrical relations between the $T_{\mathrm{RSCM}}$ isograds suggest that a significant part of large-scale structures of NMU were acquired before the HT-LP metamorphism event correlated with the extension of the continental crust during Albian-Cenomanian Stages.

\subsection{Salt Tectonics and Early Structures of the NMU.}

The correlation between structure and thermicity data shows clear evidence that the thermal pattern related to HT-LP metamorphism intersects most of the present-day architecture of the Nappes des Marbres Unit. Furthermore, the imprint of Pyrenean compressional deformation was weak in the Mesozoic sedimentary cover of the eastern BCB, contrarily to the Central Depression. Consequently, the folding episode responsible for the bulk of the present-day structure of the NMU was acquired before or, at the latest, during the HT-LP metamorphism related to extension (i.e., Cretaceous HE). One of the 
different possible explanations for developed folds with internal unconformities and diapirs during extension is the salt tectonics discussed in a previous section. The formation of diapirs and associated rim-synclines is effectively a likely explanation for this early deformation stage. The complex geometry of the NMU can be partly explained by salt tectonics associated with the occurrence of the thick Upper Triassic evaporitic layer, as commonly observed in the Western Pyrenees (Biteau \& Canérot, 2007: Canérot, 1988, 1989; Canérot and Lenoble, 1993; Canérot et al., 2005; James \& Canerot, 1999; Jammes, Manatschal, et al., 2010; Mathieu, 1986). In the central part of the NMU, the Jurassic sediments are folded in an antiform with a core of Keuper sediments corresponding to a remnant salt ridge (s.s Hudec \& Jackson, 2007) later tightened during the collisional event.

Most of the loading and extension responsible for the salt tectonics occurred during Albian-Cenomanian Stages, but the incipient salt tectonics related to loading started in the Jurassic with the deposition of the thick carbonate platform. Then, subsequent salt-structure growth was linked with the development of first extension-related structures (i.e., Cretaceous rifting) from the early Aptian onward (Roca et al., 2011; Tugend et al., 2014).

Early diapir formation during extension might have played a role in the later localization of thrusts and compressional deformation during convergence (e.g., Callot et al., 2016; Kergaravat et al., 2017). Furthermore, the foreland flexure of the Basque-Cantabrian margin developed coevally with compressional deformation that was partly accommodated by squeezing of salt diapirs during thrusting and tightening of the former minibasins. Large-scale tightening of the former minibasins is presumably responsible for the development of the regional light $\mathrm{S}_{2}$ cleavage, observed only in shale deposits. The thick evaporitic layer played an important role during rift inversion, facilitating the décollement of the sedimentary cover (Rat et al., 1983; Rowan, 2014; Turner, 1996). Shortening related to compressional deformation was thus accommodated by the salt diapirs and by the décollement layer observed at the base of the NMU in this study, promoting the preservation of the hyperextended basin structure above the décollement. Most of the compressional deformation was accommodated by the basement (i.e., Cinco Villas and Aldudes massifs) and by the post-HE sediments of the Central Depression, located under the décollement layer and the NMU.

\section{Discussion}

\subsection{Significance of the Thermal Imprint and Coeval Ductile Deformation in the NMU 7.1.1. Timing of HT-LP Metamorphism and Relation With Magmatism}

The map of the HT-LP metamorphism in the NMU reveals the occurrence of paleotemperatures above $550^{\circ}$ $\mathrm{C}$ and steep lateral thermal gradients, while the pressure conditions for the metamorphism did not exceed 3 to $5 \mathrm{kbar}$ (Mendia, 1987; Mendia and Ibarguchi, 1991). Radiochronological methods dated this event at 101 \pm 16 Ma to $81 \pm 3$ Ma (Albarède \& Michard-Vitrac, 1978a, 1978b; Montigny et al., 1986), which corresponds to late Albian to early Cenomanian and late Santonian to early Campanian, respectively. In the BCB, the westward extension of this metamorphic event is closely related to thick subaqueous sequences of differentiated basalts, trachytes, and numerous sills of alkaline dolerites (Azambre et al., 1992). Interbedded sediments associated with volcanic rocks were dated from the late Albian to Turonian ( 104 to $83 \mathrm{Ma}$; Castañares et al., 1997, 2001; Lamolda et al., 1983; Montigny et al., 1986). Thus, absolute ages confirm that the alkaline magmatism in the Basque-Cantabrian Basin is coeval with HT-LP metamorphism. At the scale of the entire Pyrenees, the alkaline magmatic activity that affected Mesozoic sediments is given as the direct consequence of lithospheric thinning during Cretaceous rifting (Azambre et al., 1992; Azambre \& Rossy, 1976; Rossy et al., 1992). Actually, HE processes originated in the Pyrenees-Basque-Cantabrian rifts during late Aptian to Albian Stages (e.g., Golberg et al., 1986; Jammes et al., 2009; Lagabrielle et al., 2010; Roca et al., 2011; Tugend et al., 2014). HT-LP metamorphism and magmatism developed coevally but magmatism was not the cause of the metamorphic event in the Pyrenean belt. In fact, although there is strong evidence of HT-LP metamorphism in the eastern BCB, associated magmatic contribution was never observed in this area.

Recent geophysical data highlight the absence of a significant remnant slab related to a subducted oceanic domain beneath the Pyrenees (Chevrot et al., 2014, 2015; Souriau et al., 2008) suggesting that the Cretaceous basins never experienced major tectonic burial in a subduction zone- this is also proven by the absence of any HP-LT metamorphism in the belt. This observation is in line with the estimation of 
maximum pressure conditions from the metamorphic rocks of the IMZ, suggesting a maximum burial and sedimentary thickness of between 5 and $6 \mathrm{~km}$. The limited burial and the maximum temperature recorded in the sedimentary cover of the NPZ (Clerc et al., 2015) and now along the entire length of the belt with the eastern BCB $T_{\mathrm{RSCM}}$ suggest a high geothermal gradient responsible for HT-LP metamorphism $\left(600^{\circ} \mathrm{C}\right.$ - 2 to 4 kbar, i.e., Golberg \& Leyreloup, 1990) in the hyperextended domain. Considering these temperature and pressure conditions, this geothermal gradient may have reached a value higher than $80^{\circ} \mathrm{C} / \mathrm{km}$ (Hart et al., 2017; Vacherat et al., 2014). Besides thermal conduction, such a high gradient may be explained by fluid circulation associated with a blanketing effect of the sedimentary cover (Boulvais, 2016; Clerc et al., 2015; Hart et al., 2017). In fact, in the Pyrenean-Cantabrian belt, the blanketing effect is probably reinforced by thick shale and calcareous turbiditic to hemipelagic sedimentary deposits resulting from four main subsidence pulses from Aptian to Albian (Garcia-Mondejar et al., 2005). These uppermost Albian to early Cenomanian sedimentary series filling the basin are transgressive southward above the Paleozoic massifs, attesting to a sea-level rise and a high subsidence rate in the eastern BCB (Bodego et al., 2015). Furthermore, this sedimentation was ascribed to high post-rift thermal subsidence (Vergés \& GarcíaSenz, 2001).

7.1.2. Thermicity Related to HE and Mantle Exhumation

The only known outcrops of lherzolite bodies in the Basque-Cantabrian Basin are found near Ziga in the eastern NMU. They consist of brecciated serpentinized lherzolites and ophicalcites with large fractures filled with calcite (Mendia \& Ibarguchi, 1991, DeFelipe et al., 2017). According to Mendia and Ibarguchi (1991), Cr and $\mathrm{Na}$ contents in clinopyroxenes indicate that the Ziga lherzolite is of sub-continental origin. Unfortunately, because of poor outcropping conditions, the structural relationships between the lherzolites and the surrounding Mesozoic sediments cannot be observed. Interestingly, this outcrop is located in the eastern NMU where $T_{\mathrm{RSCM}}$ are moderate around $350-400^{\circ} \mathrm{C}$, a very different situation compared to the rest of the NPZ, where lherzolite bodies are in direct contact with Mesozoic carbonates (e.g., Clerc et al., 2012, 2013; Fabriès et al., 1991, 1998; Lagabrielle \& Bodinier, 2008; Monchoux, 1970; St Blanquat et al., 2016). There, $T_{\mathrm{RSMC}}$ values recorded close to the mantle exposures are high, usually exceeding $\sim 500^{\circ} \mathrm{C}$ (Clerc et al., 2015). In the Basque-Cantabrian belt, synrift mantle exhumation required a top-basement detachment system(s) at the base of the basin (Pedrera et al., 2017; Roca et al., 2011; Tugend et al., 2014; Turner, 1996). It is noteworthy that Roca et al. (2011) and Tugend et al. (2014) already proposed that both the BCB and the Parentis basins on each side of the Landes High could have been formed by a north-dipping lowangle detachment fault above hyperthinned crust and exhumed mantle. More recently Pedrera et al. (2017) alternatively proposed a HE model with a south dipping low-angle fault in the BCB.

\subsubsection{Spatial Association of Ductile Deformation and High Temperature}

The structural data described in this paper highlight the occurrence of a ductile $\mathrm{S}_{1}$ foliation generally transposing the former bedding. We observed that this ductile fabric is systematically spatially associated with the highest $\mathrm{T}_{\mathrm{RSCM}}$ values along the northern NMU, i.e. close to the Leitza fault. We thus interpret this ductile deformation as the structural record of HE and detachment faulting that acted below the NMU, ultimately controlling mantle exhumation, as reported for the NPZ further east (e.g., Clerc et al., 2015). Alternatively, this ductile deformation could be partly due to the inversion of the basin during the early orogeny (Santonian in age). Indeed, as previously described, the metamorphic event in the NMU was dated at 101 to $81 \mathrm{Ma}$ (Albarède \& Michard-Vitrac, 1978a, 1978ab; Montigny et al., 1986), whereas the onset of the convergence in the Pyrenean-Cantabrian is dated at $84 \mathrm{Ma}$. The ages show an overlap of the end of the metamorphic event and the onset of the convergence, implying that a part of the basin was still hot during its inversion. Vacherat et al. (2014) suggested that the high geothermal gradient lasted $30 \mathrm{Myr}$ after the onset of the convergence. This thermal relaxation timing could explain the persistence of high temperatures in the basin. However, we have seen that the Pyrenean shortening had limited effects on the NMU and this interpretation is thus less likely.

\subsection{Restoration of the Rift Architecture of the Eastern BCB}

As previously discussed, the formation of sedimentary basins from the late Aptian to the Cenomanian in the eastern BCB (including the NMU) is related to crustal HE, ultimately leading to subcontinental mantle exhumation. However, stratigraphic, structural, and thermal observations are not sufficient to be fully conclusive about the deep crustal structure. Therefore, two alternative crustal-scale structural models with the same first-order stratigraphic architecture can be proposed for the late rift geometry of the NMU (Figure 15). 

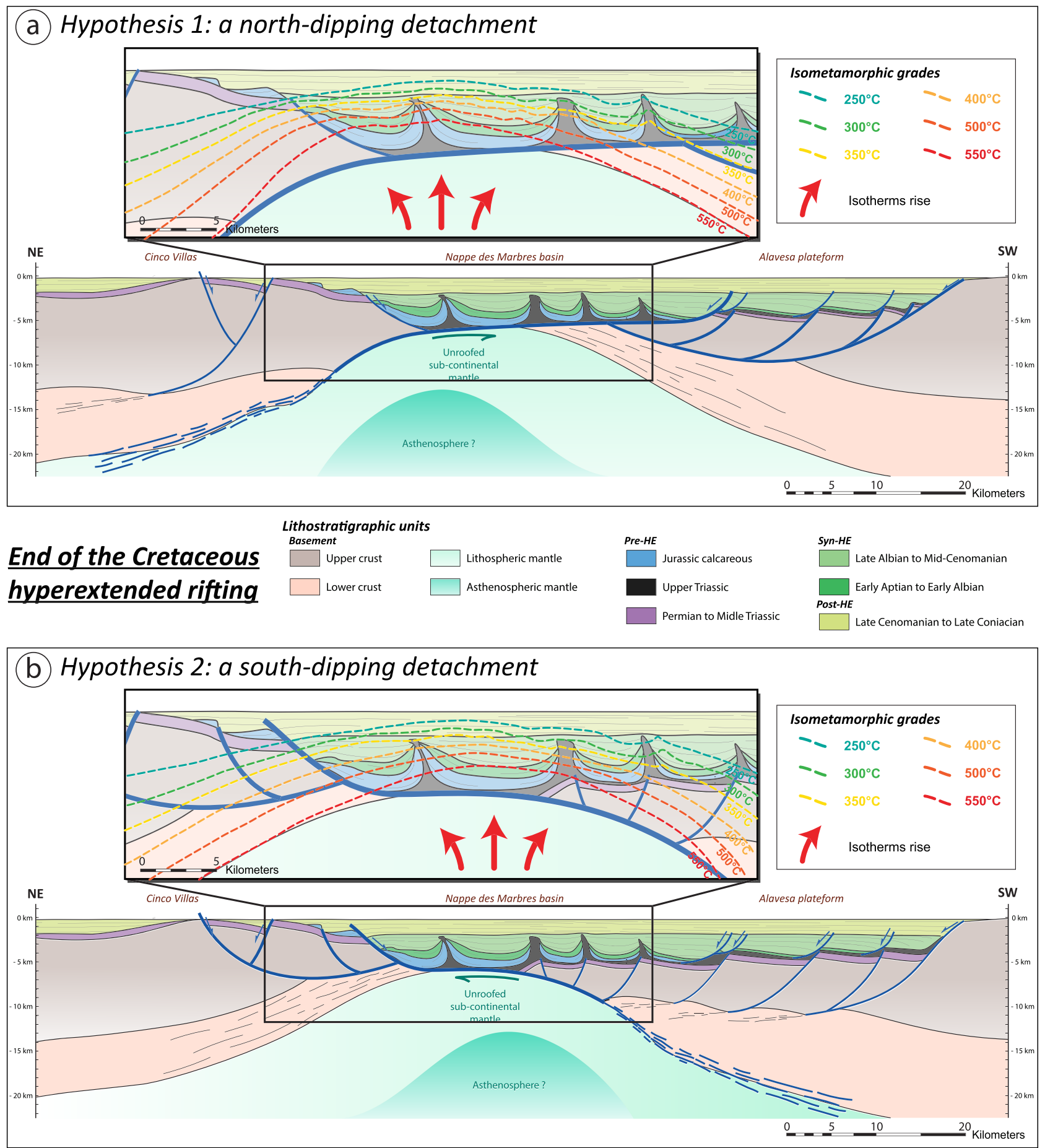

Figure 15. Two hypotheses regarding the late-rift geometry and stratigraphic architecture of the eastern BCB at the top of the post-HE sediments. (a) The first hypothesis with a north-dipping detachment fault related to hyper-extension. (b) The second hypothesis with a south dipping detachment fault related to hyperextension. Close-up views focus on the distribution of the isotherms in the sedimentary cover of the Nappe des Marbres Unit (NMU).

\subsubsection{Stratigraphic Architecture: Interaction Between HE and Salt Tectonics}

In both models, presented in Figure 15, the basin structure respects the observed regional thickening of the syn-HE sediments controlled by the diapirs and salt ridge growth. This type of salt-related architecture, typically observed during rifting, is more prevalent where the thermal peak is recorded. In addition, at basinscale, a gradual north-south thickening of the syn-HE sequence is also observed. At regional and basin 
scale this gradual thickening of the syn-HE accommodation space can be interpreted as a gentle south-dipping slope and progressive deepening of the pre-HE basement. In the northern NMU, the reconstructed crosscutting relationship between the bedding of the syn-HE sediments and the palaeo-isotherms argues for synrift folding. This folding may be related to salt tectonics developed in the deepest part of the basin (Figure 15a), with the associated rimmed depocenters. Pre-HE and syn-HE sediments are affected by the syn-HE salt tectonics that controlled the structural style and sedimentary sequence deposited above the Upper Triassic series (Keuper), as highlighted by thickness and facies variations (e.g., Bodego et al., 2015; Iriarte, 2004; Pedrera et al., 2017), and by the development of extensional folds (Martinez-Torres, 1989). The salt tectonics resulted in the formation of salt ridges and diapirs, rim-synclines, and minibasins. Blocks of subsalt material in the percing diapirs are evidence that the salt diapirs most probably reached the seabed at the end of rifting or during early convergence. Salt tectonics was still active during and after convergence as demonstrated by the intrusion of salt diapirs into synconvergence and postconvergence strata.

The lack of syn-HE strata and the draping of post-HE strata onlapping directly over the Cinco Villas massif (palaeo-high) argue for a preorogenic slope between the Central Depression and the NMU. Considering this synrift to postrift south dipping basement slope between the Cinco Villas massif and the NMU, the discontinuous slivers of pre-HE carbonates above the south dipping Lower Triassic sandstones may be remnants of south-oriented extensional rafts, arguably assisted by the Triassic salt layer acting as the main décollement (Figure 15a). During the first stage of rifting, related to crustal stretching, the salt layer decoupled the sedimentary cover from the basement. Consequently, the mode of deformation of the sedimentary cover is different from that of the subsalt units (see Jammes, Manatschal, et al., 2010; Rowan et al. 2014) corresponding to the basement and Lower Triassic sediments. In the later rifting stage, after migration or thinning out of the salt layer, the sedimentary cover and the basement were locally coupled, exposing the detachment fault at the surface and explaining the observed unconformities (Jammes, Manatschal, et al., 2010). In the NMU, the observed ductile fabric could have developed during the coupling of the sedimentary cover (i.e. pre-HE layers) and the basement, along the detachment plane.

\subsubsection{Crustal Structure: Asymmetric HE}

As discussed above, two main crustal-scale interpretations can be proposed to fit the above-mentioned stratigraphic record. They involve either north or south directed top-basement exhumation faults responsible for crustal thinning and mantle exhumation in the NMU. During incipient rifting, the extension was accommodated by a series of normal faults, crosscut by the main low-angle extensional fault associated with ductile deformation in the lower crust and mantle exhumation. In both cases, the asthenospheric rise is located below the area of the HT-LP metamorphic climax, assuming that thermal diffusion was mainly conductive. It is noteworthy however that former studies also pointed out the potential importance of fluid circulation below the Pyrenean rift basin, as a first-order control of the thermal architecture (e.g., Boulvais, 2016; Clerc et al., 2015; Corre et al., 2018; Salardon et al., 2017).

In the first scenario, the rifting phase is associated with a north dipping low-angle normal fault in the basement (Figure 15a). This fault system accommodated the extreme crustal thinning of continental crust until parts of the mantle were exhumed. In this model, the Leitza fault that limits the Central Depression to the south corresponds to a hanging-wall antithetic fault of the NMU detachment system that accommodated a "crustal roll-over" of the European crust (Figure 15a). This crustal rotation would have controlled the south dipping slope across the Central Depression and the subsequent south-directed gravity slides of pre-HE sedimentary cover. Thus, part of the NMU pre-HE cover may be allochthonous and may have originated from the slid cover of the Central Depression and Cinco Villas massif.

In the first model (Figure 15a), synthetic normal faults of the NMU detachment rooted in the basal salt décollement controlled rotating faulted blocks and syntectonic growth strata (Figure 15a). In this structural template, the $S_{1}$ foliation, corresponding to the HT-LP ductile extensional fabric, affected the sedimentary cover (both pre-HE and syn-HE) and remained above the basal décollement. This deformation was most intense where the sedimentary cover was welded to the basement of the supposed hyperthinned crustal and exhumed mantle domains, south of the Leitza fault.

Conversely, in the second scenario, crustal thinning was accommodated by a south dipping low-angle fault (Figure 15b). In this case the southern margin of the Cinco Villas Massif and the Central Depression, that is, 
the Leitza Fault, corresponds to the main detachment fault structure. In this structural template, gravitational sliding of pre-HE sediments as well as syn-HE growth strata (Figure 15b) occurs above this major fault plane. South of the Leitza detachment system, the NMU directly overlies the exhumed mantle and thinned continental crust. As in the first model, the NMU sedimentary cover may also result from north directed gravity sliding of the former Iberian pre-HE and syn-HE sediments. In a more "symmetrical" interpretation, this top-basement décollement could also be a hanging-wall antithetic structure of the Leitza detachment fault (if not a north-dipping master fault). In this case, the eastern BCB can be seen as a basin formed between two crustal-scale boudins within the European and Iberian boudinaged crusts. In this interpretation, the overall behavior of the crust is more ductile and thus hot, as proposed by Clerc and Lagabrielle (2014) for parts of the Pyrenees further east or for some of the South Atlantic or South China Sea margins (Clerc et al., 2018; Savva et al., 2013).

\subsubsection{Thermal Structure of the Rift Basin}

Close-up views in Figure 15 illustrate the attitude of isotherms in the basin during the HT-LP metamorphic event. Both scenarios are similar to that of the first-order, the differences lying in the offset of the asthenospheric rise below the rift basin and the asymmetry of the isotherms more acutely expressed in a deeper level of the lithosphere. In addition, the asymmetry of the rifted margins during lithospheric thinning is linked to the asymmetry of the isotherms, as proposed by Brune et al. (2014). This isotherm asymmetry may explain the position of the thermal anomaly related to the mantle exhumation as well as the thermal gradient observed in the eastern $\mathrm{BCB}$. At basin-scale, the highest temperatures (exceeding $550^{\circ} \mathrm{C}$ ) are found in the deepest parts of the rift basin, that is, in its northern border. As demonstrated by exposed parts of the mantle and further suggested by tectonic subsidence, this area may correspond to the former zone of hyperthinned crust and exhumed mantle. In detail, our thermal data suggest that the actual thermal architecture may be complex and more "patchy" in 3-D. Both vertical and lateral rapid $T_{\mathrm{RSCM}}$ variations suggest that the thermal gradient may be extremely heterogeneous spatially. This observation may alternatively result from a more complex crustal/lithospheric architecture relative to non-cylindricity, conductivity anomalies (e.g., high salt conductivity) or due to the contribution of fluid flow (e.g., convective regime due to hydrothermal circulation, as suggested by Iriarte, 2004).

\subsection{Comparison With the NPZ}

The eastern Basque-Cantabrian Basin revealed the same characteristics as the NPZ in the Pyrenees for the age and intensity of the HT-LP metamorphism, age, and type of synrift sediments as well as for the alkaline magmatism. The thermal anomaly responsible for the development of the HT-LP metamorphic event in the NPZ is generally attributed to a very high geothermal gradient related to an intense crustal and lithospheric thinning episode during the Cretaceous (Clerc et al., 2015; Dauteuil \& Ricou, 1989; Golberg, 1987; Golberg \& Leyreloup, 1990; Golberg \& Maluski, 1988; Lagabrielle et al., 2016; Vielzeuf \& Kornprobst, 1984). The same ductile fabric at the base of the rift basin (and above the so-called hyperthinned crustal domains) is also evidenced in both cases (Clerc et al., 2015; Clerc \& Lagabrielle, 2014; Golberg, 1987; Golberg \& Leyreloup, 1990; Lagabrielle et al., 2010). The NMU may therefore be considered as a westward analog of the NPZ, especially the IMZ.

It has been proposed that the metamorphic intensity decreased from east to west across the Pyrenees (Bernus-Maury, 1984; Clerc et al., 2015; Golberg \& Leyreloup, 1990; Ravier, 1959). For Clerc and Lagabrielle (2014), this gradient results from an evolution in the mode of rifting that varied from ductiledominated at higher temperatures to brittle at lower temperatures. The thermal record documented in this study shows, instead, that the westernmost part of the belt recorded maximum temperatures in the same range as those recorded in the IMZ in the rest of the Pyrenees $\left(\sim 600^{\circ} \mathrm{C}\right)$. Therefore, the pattern of large-scale thermal gradient at the scale of the belt appears quite more complex than a just a temperature increase from west to east.

\section{Conclusions}

The eastern Basque-Cantabrian Basin (i.e., NMU), which partly escaped from the Pyrenean collisional overprint, is an ideal area to study the architecture and thermicity of an hyperextended rift basin. The moderate intensity of the Pyrenean shortening allows accessing the structural, stratigraphic, and thermal archives of synrift HE processes interacting with early salt tectonics. We use new structural and RSCM data to 
characterize the architecture and the spatial distribution of the HT-BP metamorphism in the Eastern BCB. The key observations of this study focused on the NMU can be summarized as follows:

1. Two main tectonic phases can be described: a first phase consisting in a HT-LP deformation with ductile foliation related to HE processes below a mechanically decoupled sedimentary basin affected by active salt tectonics and a second shortening phase consisting in the development of the pervasive slaty cleavage in shale sediments, preferentially observed in the Central Depression.

2. The spatial distribution of HT-LP metamorphism obtained with the RSCM method further indicates maximum-temperatures exceeding $570^{\circ} \mathrm{C}$ in the central part of the NMU with tight N-S and E-W kilometer gradients. Isograds intersect the large-scale folding-related structure of the NMU. Therefore, a large part of the NMU structure was acquired before or during the metamorphism episode and a fortiori before shortening.

3. These early structures are likely related to salt tectonics (i.e., diapirs, salt ridge, and minibasins) related to the thick Upper Triassic evaporitic layer. This layer acted as a décollement level flooring the NMU and as a decoupling horizon between the sedimentary cover and the basement. Following the building of reactive salt structures such as diapirs and ridges, this level is responsible of gravity-driven gliding of the detached sedimentary cover during the rifting phase.

4. The subsequent convergence overprint corresponds to a slight tightening of the former hyperextended basin, while thrusts are localized along the former diapirs and salt ridges.

Finally, with the above-mentioned geological archive, the NMU may be used as an analog of a hyperextended rift basin that interacted with synrift salt tectonics to understand the structural, temporal and thermal evolution of present-day hyperextended rifted margins.

\section{Acknowledgments}

All the data used in this paper can be obtained in the figures, references, and supporting information. Additionally, these data are easily accessible with this link: http://dx.doi.org/10.17632/ 4xbsmd4jp6.2. This work has received funding from the Labex Voltaire and from the Institut Universitaire de France. It is a contribution of the Labex VOLTAIRE. This work was realized within the scope of the "Référentiel Géologique de la France” (RGF) developed by the French geological survey (BRGM). We are grateful to $\mathrm{S}$. Janiec and J.G. Badin (ISTO) for the preparation of thin sections and A. Menant and R. Augier for many discussions on the Pyrenean range and their constructive comments. Many thanks to Julie Tugend and Sylvain Calassou for their helpful insight and the organization of the discussion part of this manuscript. Thanks to Gianreto Manatschal, Josep Anton Muñoz, and one anonymous reviewers for comments that have been helpful to clarify and improve this manuscript.

\section{References}

Ábalos, B. (2016). Geologic map of the Basque-Cantabrian Basin and a new tectonic interpretation of the Basque Arc. International Journal of Earth Sciences, 105(8), 2327-2354. https://doi.org/10.1007/s00531-016-1291-6

Agirrezabala, L.M., García-Mondéjar, J., (1989). Evolución tectosedimentaria de la plataforma urgoniana entre Cabo Ogoño e Itziar (Aptiense-Albiense superior, Región Vasco-Cantábrica Nor-Oriental). In: XII Congreso Español de Sedimentología. Simposio 11-20. Bilbao.

Albarède, F., \& Michard-Vitrac, A. (1978a). Age and significance of the North Pyrenean metamorphism. Earth and Planetary Science Letters, 40, 327-332.

Albarède, F., \& Michard-Vitrac, A. (1978b). Datation du metamorphisme des terrains secondaires des Pyrenees par les methodes (super 39) Ar- (super 40) Ar et (super 87) Rb- (super 87) Sr; ses relations avec les peridotites associees. Bulletin de la Societe Geologique de France, 20, 681-687.

Arthaud, F., \& Matte, P. (1975). Les decrochements tardi-hercyniens du sud-ouest de l'europe. Geometrie et essai de reconstitution des conditions de la deformation. Tectonophysics, 25, 139-171. https://doi.org/10.1016/0040-1951(75)90014-1

Arthaud, F., \& Matte, P. (1977). Late Paleozoic strike-slip faulting in southern Europe and northern Africa: Result of a right-lateral shear zone between the Appalachians and the Urals. GSA Bulletin, 88, 1305-1320. https://doi.org/10.1130/0016-7606(1977)88<1305: LPSFIS>2.0.CO;2

Autin, J., Leroy, S., Beslier, M. O., d'Acremont, E., Razin, P., Ribodetti, A., et al. (2010). Continental break-up history of a deep magma-poor margin based on seismic reflection data (northeastern Gulf of Aden margin, offshore Oman). Geophysical Journal International, 180(2), 501-519. https://doi.org/10.1111/j.1365-246X.2009.04424.x

Azambre, B., \& Rossy, M. (1976). Le magmatisme alcalin d'age cretace, dans les Pyrenees occidentales et l'Arc basque; ses relations avec le metamorphisme et la tectonique. Bulletin de la Societe Geologique de France, S7-XVIII, 1725-1728. https://doi.org/10.2113/gssgfbull.S7XVIII.6.1725

Azambre, B., Rossy, M., \& Albarede, F. (1992). Petrology of the alkaline magmatism from the Cretaceous North-Pyrenean rift zone (France and Spain). European Journal of Mineralogy, 4, 813-834.

Azambre, B., Rossy, M., \& Lago, M. (1987). Caractéristiques pétrologiques des dolérites tholéitiques d'âge triasiques (ophites) du domaines pyrénéen, B. Mineral., 110, 379-96.

Badillo, J. M. (1982). Estudio geológico del sector de Ramales de la Victoria (Prov. de Santander). Kobie, 12, 139-166.

Barnett-Moore, N., Müller, D. R., Williams, S., Skogseid, J., \& Seton, M. (2016). A reconstruction of the North Atlantic since the earliest Jurassic. Basin Research, 30, 160-185.

Beaumont, C., Muñoz, J. A., Hamilton, J., \& Fullsack, P. (2000). Factors controlling the Alpine evolution of the central Pyrenees inferred from acomparison of observations and geodynamical models. Journal of Geophysical Research, 105(B4), 8121-8145. https://doi.org/ 10.1029/1999JB900390

Beltrando, M., Manatschal, G., Mohn, G., Dal Piaz, G. V., Vitale Brovarone, A., \& Masini, E. (2014). Recognizing remnants of magma-poor rifted margins in high-pressure orogenic belts: The Alpine case study. Earth-Science Reviews, 131, 88-115.

Bernus-Maury, C., (1984). Etude des paragenèses caractéristiques du métamorphisme mésozoïque dans la partie orientale des Pyrénées (French). Paris 6.

Beyssac, O., Goffé, B., Chopin, C., \& Rouzaud, J. N. (2002). Raman spectra of carbonaceous material in metasediments: A new geothermometer. Journal of Metamorphic Geology, 20, 859-871. https://doi.org/10.1046/j.1525-1314.2002.00408.x

Beyssac, O., Rouzaud, J.-N., Goffé, B., Brunet, F., \& Chopin, C. (2002). Graphitization in a high-pressure, low-temperature metamorphic gradient: A Raman microspectroscopy and HRTEM study. Contributions to Mineralogy and Petrology, 143, 19. 
Biteau, J., \& Canérot, J. (2007). La chaine des Pyrenees et ses avant-pays d'Aquitaine et de l'Ebre: caracteristiques structurales, evolution geodynamique et tectono-sedimentaire. GEOLOGUES-PARIS-, 155, 16.

Biteau, J. J., Le Marrec, A., Le Vot, M., \& Masset, J. M. (2006). The aquitaine basin. Petroleum Geoscience, 12(3), $247-273$.

Bodego, A., \& Agirrezabala, L. M. (2013). Syn-depositional thin- and thick-skinned extensional tectonics in the mid-Cretaceous Lasarte subbasin, western Pyrenees. Basin Research, 25(5), 594-612. https://doi.org/10.1111/bre.12017

Bodego, A., Iriarte, E., Agirrezabala, L. M., García-Mondéjar, J., \& López-Horgue, M. A. (2015). Synextensional mid-Cretaceous stratigraphic architecture of the eastern Basque-Cantabrian basin margin (western Pyrenees). Cretaceous Research, 55, 229-261. https://doi. org/10.1016/j.cretres.2015.01.006

Bodego, A., Iriarte, E., López-Horgue, M. A., \& Álvarez, I. (2018). Rift-margin extensional forced folds and salt tectonics in the eastern Basque-Cantabrian rift basin (western Pyrenees). Marine and Petroleum Geology, 91, 667-682.

Boillot, G. (1984). Les marges continentales stables et leur destin. Bulletin de la Société Géologique de France, 7(3), 517-531.

Boillot, G. (1986). Comparison between the Galicia and Aquitaine margins. Tectonophysics, 129, 243-255. https://doi.org/10.1016/00401951(86)90254-4

Boillot, G., Capdevila, R., Hennequin-Marchand, I., Lamboy, M., \& Lepretre, J.-P. (1973). La zone nord-pyreneenne, ses prolongements sur la marge continentale nord-espagnole et sa signification structurale. Elongation North. Pyrenees Zone Cont. Margin North. Spain Its Struct. Significance. Comptes rendus de l'Académie des Sciences, 277, 2629-2632.

Boirie, J. M., \& Souquet, P. (1982). Les poudingues de Mendibelza: dépôs de cônes sous-marins du rift Albien des Pyrénées. Bulletin des Centres de Recherches Exploration-Production Elf-Aquitaine, 6(2), 405-435.

Boulvais, P. (2016). Fluid generation in the Boucheville Basin as a consequence of the North Pyrenean metamorphism. Comptes Rendus Geoscience, 348, 301-311. https://doi.org/10.1016/j.crte.2015.06.013

Brune, S., Heine, C., Pérez-Gussinyé, M., \& Sobolev, S. V. (2014). Rift migration explains continental margin asymmetry and crustal hyperextension. Nature Communications, 5(1). https://doi.org/10.1038/ncomms5014

Brunet, M. F. (1984). Subsidence history of the Aquitaine basin determined from subsidence curves. Geological Magazine, 121(5), 421-428.

Callot, J.-P., Ribes, C., Kergaravat, C., Bonnel, C., Temiz, H., Poisson, A., et al. (2014). Salt tectonics in the Sivas basin (Turkey): crossing salt walls and minibasins. Bulletin Société Géologique France, 185, 33-42. https://doi.org/10.2113/gssgfbull.185.1.33

Callot, J. P., Salel, J. F., Letouzey, J., Daniel, J. M., Mengus, J. M., Pillot, D., \& Ringenbach, J. C. (2016). Three-dimensional evolution of salt controlled minibasins: Interactions, folding and megaflap development. American Association of Petroleum Geologists Bulletin, 100 $1419-1442$.

Campos, J. (1979). Estudio geológico del Pirineo vasco al W del río Bidasoa. Munibe, SC Aranzadi, 31(1-2), 3-139.

Canérot, J. (1988). Manifestations de l'halocinèse dans les chaînons béarnais (zone Nord-Pyrénéenne) au Crétacé inférieur. Comptes Rendus de l'Académie des Sciences. Série 2, Mécanique, Physique, Chimie, Sciences de L'univers, Sciences de la Terre, 306, $1099-1102$.

Canérot, J. (1989). Early Cretaceous rifting and salt tectonics on the Iberian margin of the Western Pyrenees (France). Structural consequences. Research Gate, 13, 87-99.

Canérot, J. (2016). The Iberian Plate: Myth or reality? Boletín Geológico y Minero, 127(2/3), 557-568. ISSN: 0366-0176

Canérot, J. (2017). The pull apart-type Tardets-Mauléon Basin, a key to understand the formation of the Pyrenees. Bulletin Société géologique de France, 18, 35. https://doi.org/10.1051/bsgf/2017198

Canérot, J., Hudec, M., \& Rockenbauch, K. (2005). Mesozoic diapirism in the Pyrenean orogen: Salt tectonics on a transform plate boundary. AAPG Bulletin, 89, 211-229.

Canérot, J., \& Lenoble, J. L. (1993). Diapirisme cretace sur la marge iberique des Pyrenees occidentales; exemple du pic de Lauriolle comparaisons avec l'Aquitaine, les Pyrenees centrales et orientales. Bulletin de la Société Géologique de France, 164(5), 719-726.

Capote, R. (1983). La fracturacion subsecuente a la orogenia hercinica. In J. A. Comba (Ed.), Geol. Esp., Inst. Geol. Min. España, (Vol. II, pp. 17-25). Madrid Tomo: IGME.

Carbayo, A., León, L., Villabolos, L., (1977). Mapa Geológico de España E, 1:50.000, Hoja 115, Gulina, Inst. Geol. y Minero de España (IGME), Spain

Carola, E., Muñoz, J. A., \& Roca, E. (2015). The transition from thick-skinned to thin-skinned tectonics in the Basque-Cantabrian Pyrenees: The Burgalesa Platform and surroundings. International Journal of Earth Sciences, 104(8), 2215-2239.

Castañares, L. M., Robles, S., \& Bravo, J. C. V. (1997). Distribucion estratigrafica de los episodios volcanicos submarinos del AlbienseSantoniense en la Cuenca Vasca (sector Gernika-Plentzia, Bizkaia). Geogaceta, 22, 43-46.

Castañares, L. M., Robles, S., Gimeno, D., \& Bravo, J. C. V. (2001). The Submarine Volcanic System of the Errigoiti Formation (AlbianSantonian of the Basque-Cantabrian Basin, Northern Spain): Stratigraphic Framework, Facies, and Sequences. Journal of Sedimentary Research, 71, 318-333. https://doi.org/10.1306/080700710318

Chelalou, R., Nalpas, T., Bousquet, R., Prevost, M., Lahfid, A., Poujol, M., et al. (2016). Tectonics, tectonophysics: New sedimentological, structural and paleo-thermicity data in the Boucheville Basin (eastern North Pyrenean Zone, France). Comptes Rendus - Géoscience. https://doi.org/10.1016/j.crte.2015.11.008

Chenin, P., Manatschal, G., Lavier, L. L., \& Erratt, D. (2015). Assessing the impact of orogenic inheritance on the architecture, timing and magmatic budget of the North Atlantic rift system: A mapping approach. Journal of the Geological Society of London, 172, 711-720. https://doi.org/10.1144/jgs2014-139

Chevrot, S., Sylvander, M., Diaz, J., Ruiz, M., \& Paul, A. (2015). The Pyrenean architecture as revealed by teleseismic P-to-S converted waves recorded along two dense transects. Geophysical Journal International, 200, 1094-1105. https://doi.org/10.1093/gji/ggu400

Chevrot, S., Villasenor, A., Sylvander, M., Benahmed, S., Beucler, E., Cougoulat, G., et al. (2014). High-resolution imaging of the Pyrenees and Massif Central from the data of the PYROPE and IBERARRAY portable array deployments. Journal of Geophysical Research: Solid Earth, 119, 6399-6420. https://doi.org/10.1002/2014JB010953

Choukroune, P. (1972). Relations entre tectonique et metamorphisme dans les terrains secondaires de la zone nord-pyreneenne centrale et orientale. Bulletin de la Société Géologique de France, 14, 3-11.

Choukroune, P. (1976). Strain patterns in the Pyrenean Chain. Philosophical Transactions of the Royal Society London Series A: Mathematical, Physics and Engineering Sciences, 283, 271-280.

Choukroune, P., \& ECORS Team (1989). The ECORS Pyrenean deep seismic profile reflection data and the overall structure of an orogenic belt. Tectonics, 8, 23-39.

Choukroune, P., \& Mattauer, M. (1978). Tectonique des plaques et Pyrenees: sur le fonctionnement de la faille transformante nord-pyreneenne; comparaisons avec des modeles actuels. Bulletin de la Société Géologique de France, 20, 689-700.

Clerc, C., Boulvais, P., Lagabrielle, Y., \& de St Blanquat, M. (2013). Ophicalcites from the northern Pyrenean belt: A field, petrographic and stable isotope study. International Journal of Earth Sciences, 103, 141-163. https://doi.org/10.1007/s00531-013-0927-z 
Clerc, C., \& Lagabrielle, Y. (2014). Thermal control on the modes of crustal thinning leading to mantle exhumation: Insights from the Cretaceous Pyrenean hot paleomargins. Tectonics, 33, 1340-1359. https://doi.org/10.1002/2013TC003471

Clerc, C., Lagabrielle, Y., Labaume, P., Ringenbach, J.-C., Vauchez, A., Nalpas, T., et al. (2016). Basement-Cover decoupling andprogressive exhumation of metamorphic sediments at hot rifted margin. Insights from the Northeastern Pyrenean analog. Tectonophysics, 686, 82-97. https://doi.org/10.1016/j.tecto.2016.07.022

Clerc, C., Lagabrielle, Y., Neumaier, M., Reynaud, J.-Y., \& de Saint Blanquat, M. (2012). Exhumation of subcontinental mantle rocks: Evidence from ultramafic-bearing clastic deposits nearby the Lherz peridotite body, French Pyrenees. Bulletin de la Societe Geologique de France, 183, 443-459.

Clerc, C., Lahfid, A., Monie, P., Lagabrielle, Y., Chopin, C., Poujol, M., et al. (2015). High-temperature metamorphism during extreme thinning of the continental crust: A reappraisal of the North Pyrenean passive paleomargin. Solid Earth, 6, 643-668. https://doi.org/ 10.5194/se-6-643-2015

Clerc, C., Ringenbach, J.-C., Jolivet, L., \& Ballard, J.-F. (2018). Rifted margins: Ductile deformation, boudinage, continentward-dipping normal faults and the role of the weak lower crust. Gondwana Research, 53, 20-40. https://doi.org/10.1016/j.gr.2017.04.030

Combes, P.-J., Peybernès, B., \& Leyreloup, A. F. (1998). Altérites et bauxites, témoins des marges européenne et ibérique des Pyrénées occidentales au Jurassique supérieur-Crétacé inférieur, à l'ouest de la vallée d'Ossau (Pyrénées-Atlantiques, France). Comptes Rendus de l'Académie des Sciences - Series IIA - Earth and Planetary Science, 327, 271-278. https://doi.org/10.1016/S1251-8050(98)80085-2

Corre, B., Boulvais, P., Boiron, M. C., Lagabrielle, Y., Marasi, L., \& Clerc, C. (2018). Fluid circulations in response to mantle exhumation at the passive margin setting in the north Pyrenean zone, France. Mineralogy and Petrology, 1-24.

Curnelle, R., Dubois, P., Seguin, J. C., Whitaker, D., Matthews, D. H., Roberts, D. G., et al. (1982). The Mesozoic-Tertiary Evolution of the Aquitaine Basin. Philosophical Transactions of the Royal Society London Series A: Mathematical, Physics and Engineering Sciences, 63.

Dauteuil, O., \& Ricou, L. E. (1989). Une circulation de fluides de haute-temperature a l'origine du metamorphisme cretace nord-pyreneen. Circ. High-Temp. Fluids Orig. North Pyrenean Cretac. Metamorph. Geodinamica Acta, 3, 237-250.

Debroas, E. J. (1978). Evolution de la fosse du flysch ardoisier de l'Albien superieur au Senonien inferieur (zone interne metamorphique des Pyrenees navarro-languedociennes). Bulletin de la Société Géologique de France, 20, 639-648.

Debroas, E. J. (1990). Le flysch noir albo-cenomanien temoin de la structuration albienne a senonienne de la Zone nord-pyreneenne en Bigorre (Hautes-Pyrenees, France). Bulletin de la Societe Geologique de France, 6, 273-285.

Debroas, E. J., \& Souquet, P. (1976). Sédimentogenèse et position structurale des flyschs crétacés du versant nord des Pyrénées centrales. Bull. Bur. Rech. Géol. Min., I, 305-320.

DeFelipe, I., Pedreira, D., Pulgar, J. A., Iriarte, E., \& Mendia, M. (2017). Mantle exhumation and metamorphism in the Basque-Cantabrian Basin (NSpain): Stable and clumped isotope analysis in carbonates and comparison with ophicalcites in the North-Pyrenean Zone (Urdach and Lherz). Geochemistry, Geophysics, Geosystems, 18, 631-652. https://doi.org/10.1002/2016GC006690

Del Valle, J., Villalobos, L., kl Bornhorst, A., de Boer, H.U., Krausse, H.F., Mohr, K., et al., (1973). Mapa Geológico de España E, 1:50.000, Hoja 90, Sumbilla, Inst. Geol. y Minero de España (IGME), Spain.

Ewert, F., (1964). Gelogie des Sudteiles der Baskischen Pyrenaen (Thesis). Munster-Diss.

Fabriès, J., Lorand, J.-P., \& Bodinier, J.-L. (1998). Petrogenetic evolution of orogenic lherzolite massifs in the central and western Pyrenees Tectonophysics, 292, 145-167. https://doi.org/10.1016/S0040-1951(98)00055-9

Fabriès, J., Lorand, J.-P., Bodinier, J.-L., \& Dupuy, C. (1991). Evolution of the Upper Mantle beneath the Pyrenees: Evidence from Orogenic Spinel Lherzolite Massifs. Journal of Petrology, Special_Volume, 55-76. https://doi.org/10.1093/petrology/Special_Volume.2.55

Ferreiro Mählmann, R., \& Le Bayon, R. (2016). Vitrinite and vitrinite like solid bitumen reflectance in thermal maturity studies: Correlations from diagenesis to incipient metamorphism in different geodynamic settings. International Journal of Coal Geology, 157, 52-73. https://doi.org/10.1016/j.coal.2015.12.008

Feuillée, P., Rat, P., (1971). Structures et paléogéographies pyrénéo-cantabriques. In: Histoire structurale du Golfe de Gascogne. Publications Institut français du Pétrole. Colloques et séminaires $\mathrm{n}^{\circ} 22$, t. 2.

Floquet, M., \& Mathey, B. (1984). Evolution sédimentologique, paléogéographique et structurale des marges ibérique et européenne dans les régions basco-cantabrique et nord-ibérique au Crétacé moyen et supérieur. Act. Lab. Sédim. Paléont. Univ. Sabatier, 1, $129-136$.

Ford, M., Hemmer, L., Vacherat, A., Gallagher, K., \& Christophoul, F. (2016). Retro-wedge foreland basin evolution along the ECORS line, eastern Pyrenees, France. Journal of the Geological Society, 173, 419-437. https://doi.org/10.1144/jgs2015-129

Frankovic, A., Eguiluz, L., \& Martínez-Torres, L. M. (2016). Geodynamic evolution of the Salinas de Añana diapir in the Basque-Cantabrian basin, western Pyrenees. Journal of Structural Geology, 83, 13-27.

Frasca, G., Gueydan, F., Brun, J. P., \& Monié, P. (2016). Deformation mechanisms in a continental rift up to mantle exhumation. Field evidence from the western Betics, Spain. Marine and Petroleum Geology, 76, 310-328.

Gabaldón, V., Fernández, J.C., Davó, A.O., Merino, J.R., Sedó, J.S., Vilches, L.V., (1983). Mapa Geológico de España E, 1:50.000, Hoja 89, Tolosa, Inst. Geol. y Minero de España (IGME), Spain.

Gabaldón, V., Merino, J.R., Davó, A.O., Vilches, L.V., González, L.L., Olivares, A.C., (1984). Mapa Geológico de España E, 1:50.000, Hoja 114, Alsasua, Inst. Geol. y Minero de España (IGME), Spain.

Gallastegui, J. (2000). Estructura cortical de la cordillera y margen continental canta'bricos: Perfiles ESCI-N, Trab. Geol., 21, Univ. de Oviedo, Spain, $231 \mathrm{pp}$

Gallastegui, J., Pulgar, J. A., \& Gallart, J. (2002). Initiation of an active margin at the North Iberian continent-ocean transition. Tectonics, 21(4), 1033. https://doi.org/10.1029/2001TC901046

García-Mondéjar, J. (1982). Tectónica sinsedimentaria en el Aptiense y Albiense de la región vascocantábrica Occidental. Cuadernos de Geologia Iberica, 8, 23-26.

García-Mondéjar, J., Agirrezabala, L. M., Aranburu, A., Fernández-Mendiola, P. A., Gómez-Pérez, I., López-Horgue, M., \& Rosales, I. (1996). Aptian-Albian tectonic pattern of the Basque-Cantabrian Basin (Northern Spain). Geological Journal, 31(1), $13-45$.

García-Mondéjar, J., \& García-Pascual, I. (1982). Estudio geológico del anticlinorio de Bilbao entre los ríos Nervión y Cadagua. Kobie, 12 , 101-137.

Garcia-Mondejar, J., Lopez-Horgue, M. A., Aranburu, A., \& Fernandez-Mendiola, P. A. (2005). Pulsating subsidence during a rift episode; stratigraphic and tectonic consequences (Aptian-Albian, northern Spain). Terra Nova, 17, 517-525. https://doi.org/10.1111/j.13653121.2005.00644.x

García-Mondejar, J., \& Robador, A. (1986-1987). Sedimentación y paleogeografía del Complejo Urgoniano (Aptiense-Albiense) en el area de Bermeo (region Vasco-Cantábrica septentional). Acta Geologica Hispánica, 21-22, 411-418.

García-Senz, J., (2002). Cuencas extensivas del Cretacico Inferior en los Pireneos Centrales - formacion y subsecuente inversion. [PhD thesis]. University of Barcelona, Barcelona. 
Garrido-Megias, A., \& Rios Aragues, L. M. (1972). Sintesis geologica del Secundario y Terciario entre los rios Cinca y Segre (Pirineo Central de la vertiente sur pirenaica, provincias de Huesca y Lerida). Boletín Geológico y Minero, 83, 1-47.

Golberg, J. M. (1987). Le metamorphisme mesozoique dans la partie orientale des Pyrenees; relations avec l'evolution de la chaine au cretace. Universite des Sciences et Techniques du Languedoc. Montpellier, France, France: Centre Geologique et Geophysique.

Golberg, J. M., \& Leyreloup, A. F. (1990). High temperature-low pressure Cretaceous metamorphism related to crustal thinning (Eastern North Pyrenean Zone, France). Contributions to Mineralogy and Petrology, 104, 194-207. https://doi.org/10.1007/BF00306443

Golberg, J. M., \& Maluski, H. (1988). Donnees nouvelles et mise au point sur l'age du metamorphisme pyreneen. Comptes rendus de l'Académie des Sciences de Paris, 306, 429-435.

Golberg, J. m., Maluski, H., \& Leyreloup, A. f. (1986). Petrological and age relationship between emplacement of magmatic breccia, alkaline magmatism, and static metamorphism in the North Pyrenean Zone. Tectonophysics, 129, 275-290. https://doi.org/10.1016/0040-1951(86) 90256-8

Handy, M. R., Schmid, S. M., Bousquet, R., Kissling, E., \& Bernoulli, D. (2010). Reconciling plate-tectonic reconstructions of Alpine Tethys with the geological-geophysical record of spreading and subduction in the Alps. Earth Science Reviews, 102, 121-158. https://doi.org/ 10.1016/j.earscirev.2010.06.002

Hart, N. R., Stockli, D. F., Lavier, L. L., \& Hayman, N. W. (2017). Thermal evolution of a hyperextended rift basin, Mauléon Basin, western Pyrenees. Tectonics, 36, 1103-1128. https://doi.org/10.1002/2016TC004365

Heddebaut, C. (1975). Etudes geologiques dans les massifs paleozoiques basques. Bulletin du Bureau de recherches geologiques et minieres, IV $-1,5-30$

Henry, P., Azambre, B., Montigny, R., Rossy, M., \& Stevenson, R. K. (1998). Late mantle evolution of the Pyrenean sub-continental lithospheric mantle in the light of new (super 40) Ar-(super 39) Ar and Sm-Nd ages on pyroxenites and peridotites (Pyrenees, France). Tectonophysics, 296, 103-123.

Heuschmidt, B., (1977). Le gîte plombo-zincifere de Modesta: (Navarre, Espagne) et ses controles tectoniques. Université Claude Bernard, Lyon.

Hudec, M. R., \& Jackson, M. P. A. (2006). Advance of allochthonous salt sheets in passive margins and orogens. AAPG Bulletin, 90 1535-1564. https://doi.org/10.1306/05080605143

Hudec, M. R., \& Jackson, M. P. A. (2007). Terra infirma: Understanding salt tectonics. Earth Science Reviews, 82, 1-28. https://doi.org/ 10.1016/j.earscirev.2007.01.001

Hudec, M. R., \& Jackson, M. P. A. (2009). Interaction between spreading salt canopies and their peripheral thrust systems. Journal of Structural Geology, 31, 1114-1129. https://doi.org/10.1016/j.jsg.2009.06.005

Hudec, M. R., Jackson, M. P. A., \& Schultz-Ela, D. D. (2009). The paradox of minibasin subsidence into salt: Clues to the evolution of crustal basins. Geological Society of America Bulletin, 1. https://doi.org/10.1130/B26275.1

Iriarte, E., (2004). Depresion Intermedia entre Leitza y Elizondo (Pirineo occidental): estratigrafía y relaciones tectonica-sedimentacion durante el Cretacico. Unpublished PhD thesis. UPV/EHU, $310 \mathrm{pp}$

Jackson, M. P. A., \& Vendeville, B. C. (1994). Regional extension as a geologic trigger for diapirism. Geological Society of America Bulletin, 106(1), 57-73.

James, V., \& Canerot, J. (1999). Diapirisme et structuration post-triasique des Pyrénées occidentale et de l'Aquitaine méridionale (France). Eclogae Geologicae Helvetiae, 63. https://doi.org/10.5169/seals-168647

James, V., Canérot, J., \& Biteau, J. J. (1996). Données nouvelles sur la phase de rifting atlantique des Pyrénées occidentales au Kimméridgien: la masse glissée d'Ouzous (Hautes Pyrénées). Géologie de la France, 3, 60-66.

Jammes, S., Lavier, L., \& Manatschal, G. (2010). Extreme crustal thinning in the Bay of Biscay and the Western Pyrenees: From observations to modeling. Geochemistry, Geophysics, Geosystems, 11, Q10016. https://doi.org/10.1029/2010GC003218

Jammes, S., Manatschal, G., \& Lavier, L. (2010). Interaction between prerift salt and detachment faulting in hyperextended rift systems: The example of the Parentis and Mauléon basins (Bay of Biscay and western Pyrenees). AAPG Bulletin, 94, 957-975. https://doi.org/10.1306/ 12090909116

Jammes, S., Manatschal, G., Lavier, L., \& Masini, E. (2009). Tectonosedimentary evolution related to extreme crustal thinning ahead of a propagating ocean: Example of the western Pyrenees. Tectonics, 28, TC4012. https://doi.org/10.1029/2008TC002406

Juch, D., \& Schäfer, D. (1974). L'Hercynien de Maya et de la vallée d'Arizakum dans la partie orientale du massif de Cinco-Villas (Pyrénées Occidentales d'Espagne). Pirineos, 111, 41-58

Kergaravat, C., Ribes, C., Callot, J.-P., \& Ringenbach, J.-C. (2017). Tectono-stratigraphic evolution of salt-controlled minibasins in a fold and thrust belt, the Oligo-Miocene central Sivas Basin. Journal of Structural Geology, 102, 75-97. https://doi.org/10.1016/j. jsg.2017.07.007

Kergaravat, C., Ribes, C., Legeay, E., Callot, J.-P., Kavak, K. S., \& Ringenbach, J.-C. (2016). Minibasins and salt canopy in foreland fold-andthrust belts: The central Sivas Basin, Turkey. Tectonics, 35, 1342-1366. https://doi.org/10.1002/2016TC004186

Klarr, K. (1974). La structure géologique de la partie sud-est du Massif des Aldudes-Quinto Real (Pyrenees Occidentales). Pirineos, 111, 41-58.

Krausse, H. F. (1973). Übersicht über die tektonischen Formungen und Strukturen in den Spanischen Westpyrenaen. Neues Jahrbuch für Geologie und Paläontologie Abhandlungen, 142, 1-29.

Krausse, H.F., Müller, D., Requadt, H., Campos Fernández, J., Garcia-Dueñas, V., Garrote, A., et al., (1972). Mapa Geológico de España E, 1:50.000, Hoja 65, Vera de Bidasoa, Inst. Geol. y Minero de España (IGME), Spain.

Lagabrielle, Y., \& Bodinier, J.-L. (2008). Submarine reworking of exhumed subcontinental mantle rocks: Field evidence from the Lherz peridotites, French Pyrenees. Terra Nova, 20, 11-21. https://doi.org/10.1111/j.1365-3121.2007.00781.x

Lagabrielle, Y., Clerc, C., Vauchez, A., Lahfid, A., Labaume, P., Azambre, B., et al. (2016). Very high geothermal gradient during mantle exhumation recorded in mylonitic marbles and carbonate breccias from a Mesozoic Pyrenean palaeomargin (Lherz area, North Pyrenean Zone, France). Comptes Rendus Geoscience, 348, 290-300. https://doi.org/10.1016/j.crte.2015.11.004

Lagabrielle, Y., Labaume, P., \& de Saint Blanquat, M. (2010). Mantle exhumation, crustal denudation, and gravity tectonics during Cretaceous rifting in the Pyrenean realm (SW Europe): Insights from the geological setting of the lherzolite bodies. Tectonics, 29, TC4012 https://doi.org/10.1029/2009TC002588

Lahfid, A., Beyssac, O., Deville, E., Negro, F., Chopin, C., \& Goffe, B. (2010). Evolution of the Raman spectrum of carbonaceous material in low-grade metasediments of the Glarus Alps (Switzerland). Terra Nova, 22, 354-360. https://doi.org/10.1111/j.1365-3121.2010.00956.x

Lamare, P., (1936). Recherches géologiques dans le Pyrénés basques d'Espagne. Mém. Société Géologique Fr. XII, 465 p.

Lamolda, M. A., Mathey, B., Rossy, M., \& Sigal, J. (1983). La edad del volcanismo cretacico de Vizcaya y Guipuzcoa. Estudios Geológicos, 39, $151-155$ 
Larrasoaña, J. C., Pares, J. M., Millan, H., del Valle, J., \& Pueyo, E. L. (2003). Paleomagnetic, structural, and stratigraphic constraints on transverse fault kinematics during basin inversion; the Pamplona Fault (Pyrenees, north Spain). Tectonics, 22(6), 1071. https://doi.org/ 10.1029/2002TC001446

Lavier, L., \& Manatschal, G. (2006). A mechanism to thin the continental lithosphere at magma-poor margins. Nature, 440, 324-328. https://doi.org/10.1038/nature04608

Le Pichon, X., Bonnin, J., Francheteau, J., \& Sibuet, J. C. (1971). In J. Debyser, X. Le Pichon, \& L. Montadert (Eds.), Une hypothèse d 'évolution tectonique du Golfe de Gascogne, in Histoire Structurale du Golfe de Gascogne, (pp. VI.11.1-VI.11.44). Paris: Institut Français du Pétrole.

Le Pichon, X., Bonnin, J., \& Sibuet, J.-C. (1970). La faille nord-pyrénéenne: faille transformante liée à l'ouverture du golfe de gascogne. Comptes rendus de l'Académie des Sciences de Paris, 271, 1941-1944.

Legeay, E., Ringenbach, J. C., Kergaravat, C., Pichat, A., Mohn, G., Vergés, J., et al. (2019). Structure and kinematics of the Central Sivas Basin (Turkey): Salt deposition and tectonics in an evolving fold-and-thrust belt. Geological Society, London, Special Publications, 490, SP490-2019.

Lemoine, M., Boillot, G., \& Tricart, P. (1987). Ultramafic and gabbroic ocean floor of the Ligurian Tethys (Alps, Corsica, Apennines): In search of a genetic model. Geology, 15, 622-625.

Leroy, S., Razin, P., Autin, J., Bache, F., d'Acremont, E., Watremez, L., et al. (2012). From rifting to oceanic spreading in the Gulf of Aden: a synthesis. Arabian Journal of Geosciences, 5(5), 859-901. https://doi.org/10.1007/s12517-011-0475-4

López-Horgue, M. A., Iriarte, E., Schroeder, S., Fernández-Mendiola, P. A., Caline, B., Corneyllie, H., et al. (2010). Structurally controlled hydrothermal dolomites in Albian carbonates of the ason valley, Basque cantabrian basin, northern Spain. Marine and Petroleum Geology, 27(5), 1069-1092. https://doi.org/10.1016/j.marpetgeo.2009.10.015

Macchiavelli, C., Vergés, J., Schettino, A., Fernàndez, M., Turco, E., Casciello, E., et al. (2017). A new southern North Atlantic isochron map: Insights into the drift of the Iberian plate since the Late Cretaceous. Journal of Geophysical Research: Solid Earth, 122, 9603-9626. https://doi.org/10.1002/2017JB014769

Manatschal, G. (2004). New models for evolution of magma-poor rifted margins based on a review of data and concepts from West Iberia and the Alps. International Journal of Earth Sciences, 93, 432-466. https://doi.org/10.1007/s00531-004-0394-7

Manatschal, G., Engström, A., Desmurs, L., Schaltegger, U., Cosca, M., Müntener, O., \& Bernoulli, D. (2006). What is the tectono-metamorphic evolution of continental break-up: the example of the Tasna Ocean-Continent Transition. Journal of Structural Geology, 28(10), 1849-1869.

Martinez-Torres, L. M., (1989). El Manto de los Marmoles (Pirineo occidental): geologia estructural y evolucion geodinamica (Thesis). Universidad del Pais Vasco, Leioa.

Martinez-Torres, L. M., Eguiluz, L., Ramon-Luch, R., \& Llanos, H. (1984). Geometría del Pirineo occidental y Arco Vasco. I Congreso español de geología, 3, 207-217.

Masini, E., Manatschal, G., Mohn, G., \& Unternehr, P. (2012). Anatomy and tectono-sedimentary evolution of a rift-related detachment system: The example of the Err detachment (central Alps, SE Switzerland). Bulletin Geological Society of America, 124, $1535-1551$.

Masini, E., Manatschal, G., Tugend, J., Mohn, G., \& Flament, J.-M. (2014). The tectono-sedimentary evolution of a hyper-extended rift basin: The example of the Arzacq-Mauleon rift system (western Pyrenees, SW France). International Journal of Earth Sciences Geologische Rundschau, 103, 1569-1596. https://doi.org/10.1007/s00531-014-1023-8

Mathey, B., Floquet, M., \& Miguel Martînez-Torres, L. (1999). The Leiza palaeo-fault: Role and importance in the Upper Cretaceous sedimentation and palaeogeography of the Basque Pyrenees (Spain). Paléo-Fail. Leiza Rô Importance Dans Sédimentation Paléogéographie Pyrén. Basqu. Au Crétac. Supér. Esp. Fr. Comptes Rendus de l'Académie des Sciences - Series IIA - Earth and Planetary Science, 328, 393-399. https://doi.org/10.1016/S1251-8050(99)80105-0

Mathieu, C. (1986). Histoire géologique du sous-bassin de Parentis. Bulletin des Centres de Recherches Exploration-Production Elf-Aquitaine, 10, 33-47.

McClay, K., Munoz, J.-A., \& Garcia-Senz, J. (2004). Extensional salt tectonics in a contractional orogen: A newly identified tectonic event in the Spanish Pyrenees. Geology, 32, 737-740. https://doi.org/10.1130/G20565.1

Mendia, M.S., (1987). Estudio petrológico de las rocas metamórfica prealpinas asociadas a la Falla de Leiza (Navarra). (Tesis de Licenciatura). Universidad del País Vasco, UPV/EHU.

Mendia, M. S., \& Ibarguchi, J. I. G. (1991). High-grade metamorphic rocks and peridotites along the Leiza Fault (Western Pyrenees, Spain) Geologische Rundschau, 80, 93-107.

Mohn, G., Manatschal, G., Müntener, O., Beltrando, M., \& Masini, E. (2010). Unravelling the interaction between tectonic and sedimentary processes during lithospheric thinning in the Alpine Tethys margins. International Journal of Earth Sciences, 99, 75-101. https://doi.org/ 10.1007/s00531-010-0566-6

Monchoux, P., (1970). Les Lherzolites pyrénéennes: contribution à l'étude de leur minéralogie, de leur genèse et de leurs transformations

Montadert, L., Roberts, D. G., De Charpal, O., \& Guennoc, P. (1979). Rifting and subsidence of the northern continental margin of the Bay of Biscay. In L. Montardet, D. G. Roberts, et al. (Eds.), Initial Reports of the Deep Sea Drilling Project, (Vol. 48, pp. 1025-1060). Washington, DC: US Government Printing Office.

Montigny, R., Azambre, B., Rossy, M., \& Thuizat, R. (1982): Etude K/Ar du magmatisme basique lié au Trias supérieur des Pyrénées Conséquences méthodologiques et pétrographiques, B. Mineral., 105, 673-680.

Montigny, R., Azambre, B., Rossy, M., \& Thuizat, R. (1986). K-Ar study of Cretaceous magmatism and metamorphism in the Pyrenees: Age and length of rotation of the Iberian Peninsula. Tectonophysics, 129, 257-273.

Mouthereau, F., Filleaudeau, P. Y., Vacherat, A., Pik, R., Lacombe, O., Fellin, M. G., et al. (2014). Placing limits to shortening evolution in the Pyrenees: Role of margin architecture and implications for the Iberia/Europe convergence. Tectonics, 33, 2283-2314. https://doi.org/ $10.1002 / 2014 \mathrm{TC} 003663$

Muñoz, J. A. (1992). Evolution of a continental collision belt; ECORS-Pyrenees crustal balanced cross-section. In K. R. Mcclay (Ed.), Thrust tectonics, (pp. 235-246). London, United Kingdom: Chapman \& Hall.

Muñoz, J. A. (2002). In W. Gibbons, \& T. Moreno (Eds.), The Pyrenees, (pp. 370-385). London: Geology of Spain Geological Socirty.

Nirrengarten, M., Manatschal, G., Tugend, J., Kusznir, N., \& Sauter, D. (2018). Kinematic evolution of the southern North Atlantic: Implications for the formation of hyperextended rift systems. Tectonics, 37, 89-118. https://doi.org/10.1002/2017TC004495

Nonn, C., Leroy, S., Khanbari, K., \& Ahmed, A. (2017). Tectono-sedimentary evolution of the eastern Gulf of Aden conjugate passive margins: Narrowness and asymmetry in oblique rifting context. Tectonophysics, 721, 322-348.

Olivet, J.-L. (1996). La cinematique de la plaque Iberique. Bulletin des Centres de Recherches Exploration-Production Elf-Aquitaine, 20, 131-195. 
Osmundsen, P. T., \& Ebbing, J. (2008). Styles of extension offshore mid-Norway and implications for mechanisms of crustal thinning at passive margins. Tectonics, 27, TC6016. https://doi.org/10.1029/2007TC002242

Pasteris, J., \& Wopenka, B. (1991). Raman-spectra of graphite as indicators of degree of metamorphism. The Canadian Mineralogist, 29, 1-9.

Pasteris, J. D. (1989). In situ analysis in geological thin-sections by laser Raman microprobe spectroscopy; a cautionary note. Applied Spectroscopy, 43, 567-570.

Pedreira, D., Pulgar, J. A., Gallart, J., \& Torné, M. (2007). Three-dimensional gravity and magnetic modeling of crustal indentation and wedging in the western Pyrenees-Cantabrian Mountains. Journal of Geophysical Research, 112, B12405. https://doi.org/10.1029/ 2007JB005021

Pedrera, A., García-Senz, J., Ayala, C., Ruiz-Constán, A., Rodríguez-Fernández, L. R., Robador, A., \& GonzálezMenéndez, L. (2017). Reconstruction of the exhumed mantle across the North Iberian Margin by crustal-scale 3-D gravity inversion and geological cross section. Tectonics, 36, 3155-3177. https://doi.org/10.1002/2017TC004716

Péron-Pinvidic, G., \& Manatschal, G. (2009). The final rifting evolution at deep magma-poor passive margins from Iberia-Newfoundland: A new point of view. International Journal of Earth Sciences, 98, 1581-1597. https://doi.org/10.1007/s00531-008-0337-9

Péron-Pinvidic, G., \& Osmundsen, P. T. (2016). Architecture of the distal and outer domains of the Mid-Norwegian rifted margin: Insights from the Rån-Gjallar ridges system. Marine and Petroleum Geology, 77, 280-299. https://doi.org/10.1016/j.marpetgeo.2016.06.014

Pesquera, A., \& Velasco, F. (1988). Metamorphism of the Palaeozoic Cinco Villas massif (Basque Pyrenees): Illite crystallinity and graphitization degree (English). Mineralogical Magazine, 52, 615-625.

Pesquera, A., \& Velasco, F. (1997). Mineralogy, geochemistry and geological significance of tourmaline-rich rocks from the Paleozoic Cinco Villas massif (western Pyrenees, Spain). Contributions to Mineralogy and Petrology, 129, 53-74. https://doi.org/10.1007/s004100050323

Peybernès, B., Fondecave-Wallez, M.-J., \& Combes, P.-J. (2003). Le front de la « Zone des marbres » (Pyrénées basco-cantabriques, Espagne), un chevauchement fini-crétacé fossilisé par les brèches marines paléocènes? Front 'Marble Zone' Basqu. Pyrenees Spain LateCretac. Overthrust Sealed Mar. Palaeocene Breccias Engl. Comptes rendus - Géoscience, 335, 335-344. https://doi.org/10.1016/S16310713(03)00050-6

Peybernes, B., \& Souquet, P. (1984). Basement blocks and tecto-sedimentary evolution in the Pyrenees during Mesozoic times. Geological Magazine, 121(5), 397-405.

Poprawski, Y., Basile, C., Agirrezabala, L. M., Jaillard, E., Gaudin, M., \& Jacquin, T. (2014). Sedimentary and structural record of the Albian growth of the Bakio salt diapir (the Basque Country, northern Spain). Basin Research, 26(6), 746-766. https://doi.org/10.1111/bre.12062

Poprawski, Y., Basile, C., Jaillard, E., Gaudin, M., \& Lopez, M. (2016). Halokinetic sequences in carbonate systems: An example from the middle Albian Bakio breccias formation (Basque Country, Spain). Sedimentary Geology, 334, 34-52. https://doi.org/10.1016/j. sedgeo.2016.01.013

Rat, P. (1988). The Basque-Cantabrian Basin between the Iberian and European plates, some facts but still many problems. Revista de la Sociedad Geológica de España, 1, 327-348.

Rat, P., Amiot, M., Feuillee, P., Floquet, M., Mathey, B., Pascal, A. \& Salomon, J. (1983). Vue sur le Cretace Basco-Cantabrique et nordibérique. Une marge et son arrière-pays, ses environnements sédimentaires. Mémoires Géologiques de l'Université de Dijon, 9 , 191 pp.

Ravier, J. (1959). Le metamorphisme des terrains secondaires des Pyrenees, Memoires Soc. Geol. Fr. Nouv. Ser., (Vol. 38). Paris: Société géologique de France.

Reitner, J. (1982). Die Entwicklung von Inselplattformen und Diapir-Atollen im Alb des Basko-Kantabrikums (Nordspanien). Neues Jahrbuch Geologisches Paläontologisches Abhanflungen, 165, 87-101.

Reston, T. J. (2009). The structure, evolution and symmetry of the magma-poor rifted margins of the North and Central Atlantic: A synthesis. Tectonophysics, 468(1-4), 6-27.

Richter, D. (1965). Faltenachsen lineare und das alter der pragungen in den Westpyrenaen, (pp. 97-110). Clausthal-Zellerfeld: Max RichterFetschrift.

Robert, P. (1971). Etude petrographique des matieres organiques insolubles par la mesure de leur pouvoir reflecteur; contribution a l'exploration petroliere et a la connaissance des bassins sedimentaires. Revue de l'Institut Francais du Petrole, 26, 105-135.

Roca, E., Muñoz, J. A., Ferrer, O., \& Ellouz, N. (2011). The role of the Bay of Biscay Mesozoic extensional structure in the configuration of the Pyrenean orogen: Constraints from the MARCONI deep seismic reflection survey. Tectonics, 30, TC2001. https://doi.org/10.1029/ 2010TC002735

Roest, W. R., \& Srivastava, S. (1991). Kinematics of the plate boundaries between Eurasia, Iberia and Africa in the North Atlantic from the Late Cretaceous to the present. Geology, 19, 613-616.

Rosenbaum, G., Lister, G. S., \& Duboz, C. (2002). Relative motions of Africa, Iberia and Europe during Alpine orogeny. Tectonophysics, 359, 117-129. https://doi.org/10.1016/S0040-1951(02)00442-0

Rossy, M., Azambre, B., \& Albarède, F. (1992). REE and Sr/1bNd isotope geochemistry of the alkaline magmatism from the Cretaceous North Pyrenean Rift Zone (France-Spain). Chemical Geology, 97, 33-46. https://doi.org/10.1016/0009-2541(92)90134-Q

Roure, F., Choukroune, P., Berastegui, X., Munoz, J. A., Villien, A., Matheron, P., et al. (1989). ECORS deep seismic data and balanced cross sections: Geometric constraints on the evolution of the Pyrenees. Tectonics, 8, 41-50. https://doi.org/10.1029/TC008i001p00041

Rowan, M. G. (2014). Passive-margin salt basins; hyperextension, evaporite deposition, and salt tectonics. Basin Research, 26, 154-182. https://doi.org/10.1111/bre.12043

Rowan, M. G., Giles, K. A., Hearon IV, T. E., \& Fiduk, J. C. (2016). Megaflaps adjacent to salt diapirs. AAPG Bulletin, 100(11), 1723-1747.

Salardon, R., Carpentier, C., Bellahsen, N., Pironon, J., \& France-Lanord, C. (2017). Interactions between tectonics and fluid circulations in an inverted hyper-extended basin: example of Mesozoic carbonate rocks of the western North Pyrenean Zone (Chaînons Béarnais, France). Marine and Petroleum Geology, 80, 563-586.

Savva, D., Meresse, F., Pubellier, M., Chamot-Rooke, N., Lavier, L., Po, K. W., \& Lamy, G. (2013). Seismic evidence of hyper-stretched crust and mantle exhumation offshore Vietnam. Tectonophysics, 608, 72-83.

Scharf, A., Handy, M. R., Ziemann, M. A., \& Schmid, S. M. (2013). Peak-temperature patterns of polyphase metamorphism resulting from accretion, subduction and collision (eastern Tauern Window, European Alps); a study with Raman microspectroscopy on carbonaceous material (RSCM). Journal of Metamorphic Geology, 31, 863-880. https://doi.org/10.1111/jmg.12048

Schroeder, R. (1979). Le calcaire de Caniego: témoin d'une montée du diapir de Valle de Mena (Prov. Burgos, Espagne) dans l'Albien supérieur. Cuadernos de Geologia Ibérica, 5, 221-225.

Schroeder, R., \& Willems, H. (1983). Uber einen submarinen Durchbruch des Diapirs von Villasana de Mena (Prov. Burgos, N-Spanicn) an der Wende Unter-/Oberkreide. Neues Jahrbuch Geologisches Paläontologisches Abhandlungen, 166, 65-85.

Sibuet, J.-C., Srivastava, S. P., \& Spakman, W. (2004). Pyrenean orogeny and plate kinematics. Journal of Geophysical Research, 109, B08104. https://doi.org/10.1029/2003JB002514 
Soto, R., Beamud, E., Roca, E., Carola, E., \& Almar, Y. (2017). Distinguishing the effect of diapir growth on magnetic fabrics of syn-diapiric overburden rocks: Basque-Cantabrian basin, Northern Spain. Terra Nova, 29(3), 191-201.

Souquet, P., Debroas, E.-J., Boirie, J.-M., Pons, P., Fixari, G., Dol, J., et al. (1985). Le Groupe du Flysch Noir (Albo-Cénomanien) dans les Pyrénées. Bulletin des Centres de Recherches Exploration Production Elf-Aquitaine Pau, 9, 183-252.

Souriau, A., Chevrot, S., \& Olivera, C. (2008). A new tomographic image of the Pyrenean lithosphere from teleseismic data. Tectonophysics, 460, 206-214. https://doi.org/10.1016/j.tecto.2008.08.014

Srivastava, S. P., Roest, W. R., Kovacs, L. C., Oakey, G., Lévesque, S., Verhoef, J., \& Macnab, R. (1990). Motion of Iberia since the Late Jurassic: Results from detailed aeromagnetic measurements in the Newfoundland Basin. Tectonophysics, 184, $229-260$.

St Blanquat, M., Bajolet, F., Grand'Homme, A., Proietti, A., Zanti, M., Boutin, A., et al. (2016). Cretaceous mantle exhumation in the central Pyrenees: New constraints from the peridotites in eastern Ariège (North Pyrenean zone, France). Comptes Rendus - Géoscience. https:// doi.org/10.1016/j.crte.2015.12.003

Stampfli, G. M., Borel, G. D., Marchant, R., \& Mosar, J. (2002). Western Alps geological constraints on western Tethyan reconstructions. Journal of the Virtual Explorer, 8, 77-106.

Sutra, E., Manatschal, G., Mohn, G., \& Unternehr, P. (2013). Quantification and restoration of extensional deformation along the Western Iberia and Newfoundland rifted margins. Geochemistry, Geophysics, Geosystems, 14, 2575-2597. https://doi.org/10.1002/ggge.20135

Tavani, S., Bertok, C., Granado, P., Piana, F., Salas, R., Vigna, B., \& Muņoz, J. A. (2018). The Iberia-Eurasia plate boundary east of the Pyrenees. Earth-science reviews. Teixell, A., 1998. Crustal structure and orogenic material budget in the west central Pyrenees. Tectonics, 17, 395-406. https://doi.org/10.1029/98TC00561

Tavani, S., Carola, E., Granado, P., Quintà, A., \& Muñoz, J. A. (2013). Transpressive inversion of a Mesozoic extensional forced fold system with an intermediate décollement level in the Basque-Cantabrian Basin (Spain). Tectonics, 32, 146-158. https://doi.org/10.1002/ tect.20019

Tavani, S., \& Granado, P. (2015). Along-strike evolution of folding, stretching and breaching of supra-salt strata in the Plataforma Burgalesa extensional forced fold system (northern Spain). Basin Research, 27(4), 573-585. https://doi.org/10.1111/bre.12089

Teixell, A. (1998). Crustal structure and orogenic material budget in the west central Pyrenees. Tectonics, 17(3), 395-406. https://doi.org/ $10.1029 / 98 \mathrm{tc} 00561$

Teixell, A., Labaume, P., Ayarza, P., Espurt, N., de Saint Blanquat, M., \& Lagabrielle, Y. (2018). Crustal structure and evolution of the Pyrenean-Cantabrian belt: A review and new interpretations from recent concepts and data. Tectonophysics, 724-725, 146-170. https:// doi.org/10.1016/j.tecto.2018.01.009

Teixell, A., Labaume, P., \& Lagabrielle, Y. (2016). The crustal evolution of the west-central Pyrenees revisited: Inferences from a new kinematic scenario. Comptes Rendus - Géoscience, 348, 257-267. https://doi.org/10.1016/j.crte.2015.10.010

Thinon, I., (1999). Structure profonde de la Marge Nord Gascogne et du Bassin Armoricain (phdthesis). Université de Bretagne occidentale Brest.

Thinon, I., L. Fidalgo-González, J.-P. Réhault, \& J.-L. Olivet (2001), Pyrenean deformations in the Bay of Biscay, C.R. Acad. Sci., Ser. IIa: Sci. TerrePlanets, 332, 561-568.

Thiébaut, J., Debeaux, M., Durand-Wackenheim, C., Souquet, P., Gourinard, Y., Bandet, Y., \& Fondecave-Wallez, M. -J. (1988). Métamorphisme et halocinèse crétacés dans les évaporitesde Betchat le long du chevauchement frontal Nord-Pyrénéen (Haute-Garonne et Ariège, France), C. R. Acad. Sci. Paris, 307, 1535-1540.

Tugend, J., Manatschal, G., Kusznir, N. J., \& Masini, E. (2015). Characterizing and identifying structural domains at rifted continental margins: Application to the Bay of Biscay margins and its Western Pyrenean fossil remnants. Geological Society of London, Special Publication, 413, 171-203. https://doi.org/10.1144/SP413.3

Tugend, J., Manatschal, G., Kusznir, N. J., Masini, E., Mohn, G., \& Thinon, I. (2014). Formation and deformation of hyperextended rift systems: Insights from rift domain mapping in the Bay of Biscay-Pyrenees. Tectonics, 33, 1239-1276. https://doi.org/10.1002/ 2014TC003529

Turner, J. P. (1996). Switches in subduction direction and the lateral termination of mountain belts; Pyrenees-Cantabrian transition, Spain Journal of the Geological Society of London, 153(Part 4), 563-571.

Vacherat, A., Mouthereau, F., Pik, R., Bernet, M., Gautheron, C., Masini, E., et al. (2014). Thermal imprint of rift-related processes in orogens as recorded in the Pyrenees. Earth and Planetary Science Letters, 408, 296-306. https://doi.org/10.1016/j.epsl.2014.10.014

Vauchez, A., Clerc, C., Bestani, L., Lagabrielle, Y., Chauvet, A., Lahfid, A., \& Mainprice, D. (2013). Pre-orogenic exhumation of the north Pyrenean Agly Massif (eastern Pyrenees, France). Tectonics, 32, 95-106. https://doi.org/10.1002/tect.20015

Vergés, J., \& García-Senz, J. (2001). Mesozoic evolution and Cainozoic inversion of the Pyrenean rift. Mémoires du Muséum national d'histoire naturelle, 186, 187-212.

Vergés, J., Fernàndez, M., \& Martínez, A. (2002), The Pyrenean orogen: Pre-, syn-, and post-collisional evolution, in Reconstruction of the Evolution of the Alpine-Himalayan Orogen, J. Virtual Explorer, vol. 8, edited by G. Rosenbaum and G. Lister, pp. 57-76, Electronic Edition, https://doi.org/10.3809/jvirtex.2002.00055.

Vergés, J., Millán, H., Roca, E., Muñoz, J. A., Marzo, M., Cirés, J., et al. (1995). Eastern Pyrenees and related foreland basins: pre-, syn- and post-collisional crustal-scale cross-sections. Marine and Petroleum Geology, 12, 903-915. https://doi.org/10.1016/0264-8172(95)98854-X

Vielzeuf, D., \& Kornprobst, J. (1984). Crustal splitting and the emplacement of Pyrenean lherzolites and granulites. Earth and Planetary Science Letters, 67, 87-96. https://doi.org/10.1016/0012-821X(84)90041-4

Vissers, R. L. M., \& Meijer, P. T. (2012). Iberian plate kinematics and Alpine collision in the Pyrenees. Earth Science Reviews, 114, 61-83. https://doi.org/10.1016/j.earscirev.2012.05.001

Vissers, R. L. M., van Hinsbergen, D. J. J., van der Meer, D. G., \& Spakman, W. (2016). Cretaceous slab break-off in the Pyrenees: Iberian plate kinematics in paleomagnetic and mantle reference frames. Gondwana Research, 34, 49-59. https://doi.org/10.1016/j.gr.2016.03.006

Walgenwitz, F., (1977). Etude pétrologique des roches intrusives triasiques, des écailles du socle profond et des gites de chlorite de la région d'Elizondo (Navarre espagnole). (Thesis). Université de Besançon, Besançon.

Wiedmann, J. (1979). Itineraire geologique à travers le Cretacé moyen dcs Chaines Vascogotiques et Celtibériques (Espagne du nod). Cuadernos de Geologia Iberica, 5, 127-214.

Wopenka, B., \& Pasteris, J. D. (1993). Structural characterization of kerogens to granulite-facies graphite: Applicability of Raman microprobe spectroscopy. American Mineralogist, 78, 533-557. 